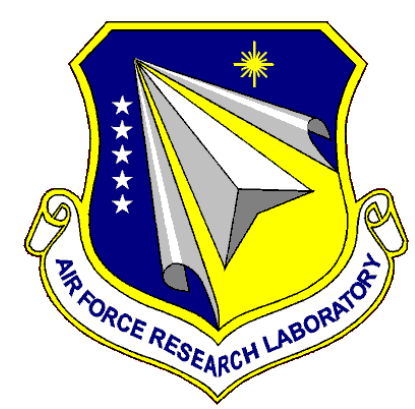

\title{
AFRL-RH-WP-TR-2015-0114
}

\section{CHARACTERIZATION OF VERTICAL IMPACT DEVICE ACCELERATION PULSES USING PARAMETRIC \\ ASSESSMENT: PHASE I}

\author{
Mr. Chris Perry \\ Mr. Chris Burneka \\ Warfighter Interface Division
}

Ms. Rachael Christopher

ORISE

Mr. Chris Albery

Infoscitex

April 2015

Interim Report

DISTRIBUTION STATEMENT A: Approved for public release. Distribution is unlimited.

\section{STINFO COPY}

AIR FORCE RESEARCH LABORATORY

711 HUMAN PERFORMANCE WING, AIRMAN SYSTEMS DIRECTORATE, WRIGHT-PATTERSON AIR FORCE BASE, OH 45433

AIR FORCE MATERIEL COMMAND

UNITED STATES AIR FORCE 


\section{NOTICE AND SIGNATURE PAGE}

Using Government drawings, specifications, or other data included in this document for any purpose other than Government procurement does not in any way obligate the U.S. Government. The fact that the Government formulated or supplied the drawings, specifications, or other data does not license the holder or any other person or corporation; or convey any rights or permission to manufacture, use, or sell any patented invention that may relate to them.

Qualified requestors may obtain copies of this report from the Defense Technical Information Center (DTIC) (http://www.dtic.mil).

\section{AFRL-RH-WP-TR-2015-0114 HAS BEEN REVIEWED AND IS APPROVED FOR PUBLICATION IN ACCORDANCE WITH ASSIGNED DISTRIBUTION STATEMENT.}

//signed//

CHRIS BURNEKA

Work Unit Manager

Applied Neuroscience Branch
$/ /$ signed//

SCOTT M. GALSTER

Chief, Applied Neuroscience Branch

Warfighter Interface Division

//signed//

WILLIAM E. RUSSELL

Chief, Warfighter Interface Division

Airman Systems Directorate

711 Human Performance Wing

Air Force Research Laboratory

This report is published in the interest of scientific and technical information exchange, and its publication does not constitute the Government's approval or disapproval of its ideas or findings. 


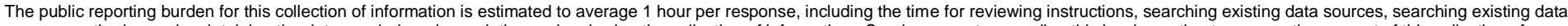

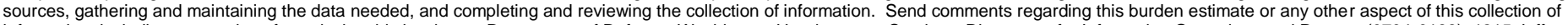

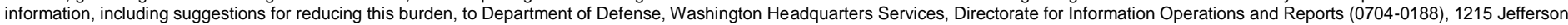

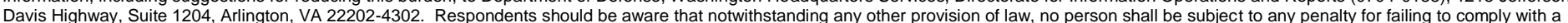
collection of information if it does not display a currently valid OMB control number. PLEASE DO NOT RETURN YOUR FORM TO THE ABOVE ADDRESS.
1. REPORT DATE (DD-MM-YY)
2. REPORT TYPE
3. DATES COVERED (From - To)
30-03-15
Interim
Jan 2013 to April 2015

\section{TITLE AND SUBTITLE}

Characterization of Vertical Impact Device Acceleration Pulses Using

Parametric Assessment: Phase I

5a. CONTRACT NUMBER

FA8650-14-D-6500-0001

5b. GRANT NUMBER

5c. PROGRAM ELEMENT NUMBER $62202 \mathrm{~F}$

6. AUTHOR(S)

Mr. Chris Perry*

Mr. Chris Burneka*

Ms. Rachael Christopher**

Mr. Chris Albery***

5d. PROJECT NUMBER

5329

5e. TASK NUMBER

08

5f. WORK UNIT NUMBER

H0GW (53290812)

\section{PERFORMING ORGANIZATION NAME(S) AND ADDRESS(ES)}

ORISE** Infoscitex Corporation***

8. PERFORMING ORGANIZATION REPORT NUMBER

Oak Ridge Institute for Science and Education Colonel Glenn Hwy, Suite 210

Oak Ridge, TN 37831 USA

Dayton, Oh 45431-4027

\section{SPONSORING/MONITORING AGENCY NAME(S) AND ADDRESS(ES)}

Air Force Materiel Command*

Air Force Research Laboratory

711 Human Performance Wing

Airman Systems Directorate

Warfighter Interface Division

Applied Neuroscience Branch

Wright-Patterson AFB, OH 45433

\begin{tabular}{l} 
10. SPONSORING/MONITORING \\
AGENCY ACRONYM(S) \\
711 HPW/RHCP \\
\hline $\begin{array}{l}\text { 11. SPONSORING/MONITORING } \\
\text { AGENCY REPORT NUMBER(S) }\end{array}$ \\
AFRL-RH-WP-TR-2015-0114
\end{tabular}

12. DISTRIBUtION/AVAILABILITY STATEMENT DISTRIBUTION STATEMENT A. Approved for public release. Distribution is unlimited.

13. SUPPLEMENTARY NOTES 88ABW Cleared 08/02/2016; 88ABW-2016-3836.

14. ABSTRACT The research effort was conducted to identify the performance capabilities of the Vertical Impact Device (VID) test located in Bldg 824, Wright Patterson AFB OH. The performance requirements for the VID were required to support the Warrior Injury Assessment Manikin (WIAMan) program which had initial impact acceleration pulse requirements of over $300 \mathrm{G}$ with pulse time-to-peak values in the 5 to $10 \mathrm{~ms}$ range. The test program approach used a parametric analysis with the objective to define and evaluate the performance effect of various impact attenuators on VID impact acceleration. Over 100 impact tests were completed to support this test program, and consisted of varying the energy attenuators, defined as the highdensity (red) urethane programmers and industrial felt of varying density and thickness, while progressively increasing the drop height of the VID's drop table. One red urethane programmer, 4 felt densities, and 4 felt thicknesses were evaluated, and were used as the basis to separate the data analysis into three sub-phases. The measured response was the acceleration recorded on the VID drop carriage, and the calculated velocity change and TTP velocity change. The first phase of the assessment evaluated the VID's red urethane programmers on the drop carriage at 8 different drop heights that ranged from 5 to 50 inches. The acceleration pulse width was used as an estimator of the time-to-peak velocity, which is the area under the acceleration curve, and was found to decrease from approximately $5.5 \mathrm{~ms}$ to $3.0 \mathrm{~ms}$ as the drop height increased from 5 inches to 50 inches. Overall, the red programmers would provide a maximum impact acceleration of approximately $650 \mathrm{G}$, and a maximum velocity change of $23 \mathrm{ft} / \mathrm{s}$ at a drop height of $80 \mathrm{inches}$. The second phase of testing indicated that the felt density variation had a minimal effect on the peak acceleration or velocity change at two drop heights, and was shown by calculating a percent difference in the response relative to a baseline which was the least dense felt. The third phase of testing indicated that the felt thickness variation had a very little effect on the velocity change at the two drop heights, but had a large effect on the peak acceleration and the acceleration pulse width at the two drop heights. This was shown by calculating a percent difference in the response relative to a baseline which was the least thick felt. The peak acceleration for the thinnest felt was $56 \%$ greater than the thickest felt at 10 inch drop height, and $65 \%$ greater than the thickest felt at a 40 inch drop height. All felt combinations could generate accelerations greater than $300 \mathrm{G}$.

15. SUBJECT TERMS Vertical impact, High-G impact, urethane programmer, felt programmer, WIAMan

\section{SECURITY CLASSIFICATION OF:}

a. REPORT

Unclassified Unclassified c. THIS PAGE Unclassified

\begin{tabular}{l|c|} 
17. LIMITATION & 18. NUMBER OF \\
OF & $\begin{array}{c}\text { PAGES } \\
\text { ABSTRACT: }\end{array}$ \\
SAR & 110
\end{tabular}

19a. NAME OF RESPONSIBLE PERSON (Monitor) Chris Burneka 19b. TELEPHONE NUMBER (Include Area Code) 


\section{TABLE OF CONTENTS}

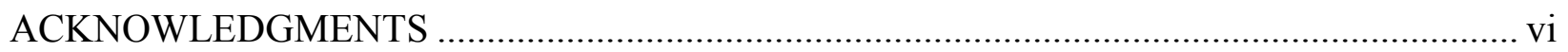

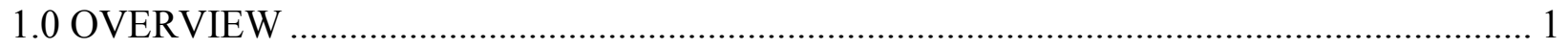

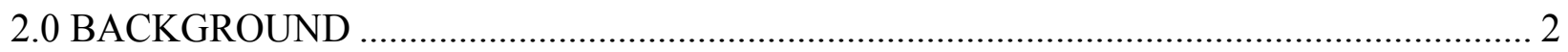

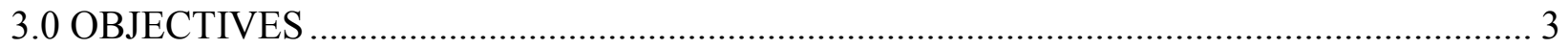

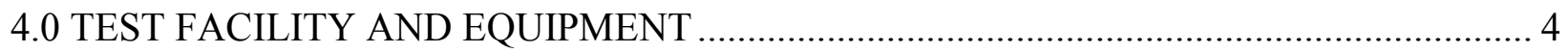

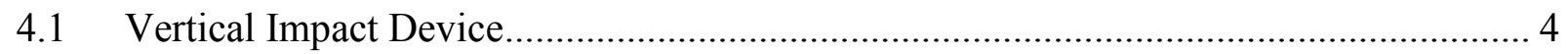

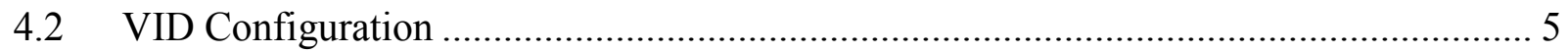

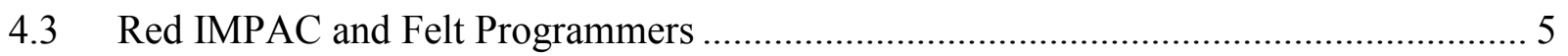

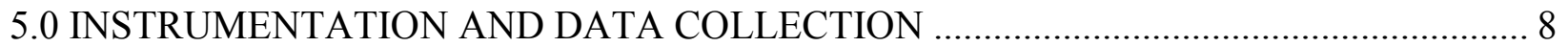

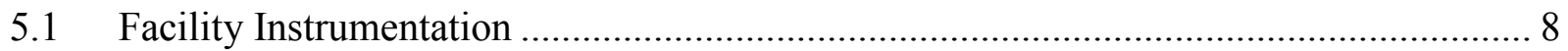

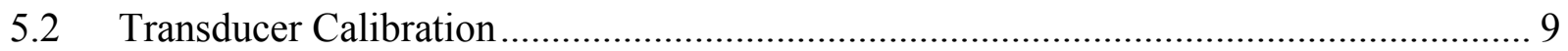

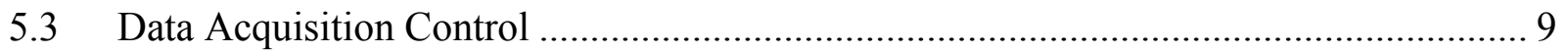

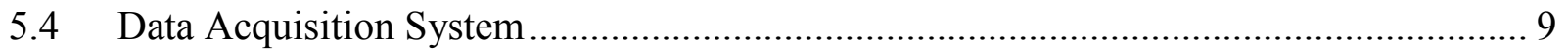

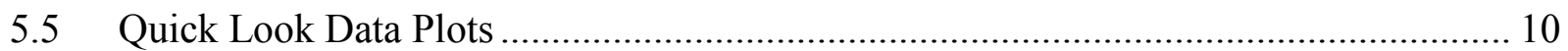

5.6 High Speed Video and Photography ..................................................................... 10

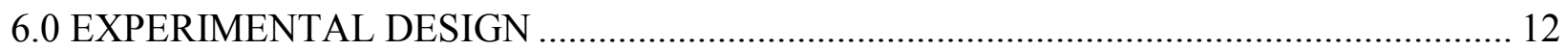

6.1 Red IMPAC Programmer Characterization ………................................................ 12

6.2 Felt Programmer Characterization ........................................................................ 13

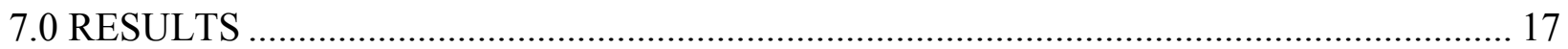

7.1 Red IMPAC Programmer: Test-by-Test Summary .................................................. 17

7.2 Red IMPAC Programmer: Test Data Review ……………………........................ 17

7.3 Felt Programmer (Density Variation): Test-by-Test Summary ……………………..... 21

7.4 Felt Programmer (Density Variation): Test Data Review............................................ 21

7.5 Felt Programmer (Thickness Variation): Test-by-Test Summary .................................... 29

7.6 Felt Programmer (Thickness Variation): Test Data Review …………………….......... 29

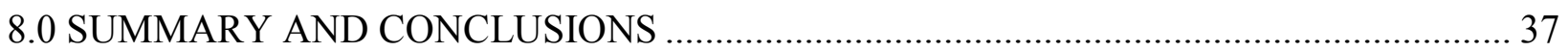

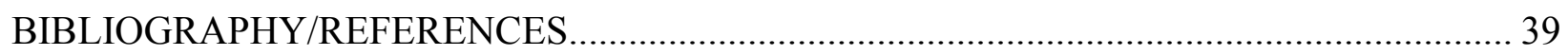

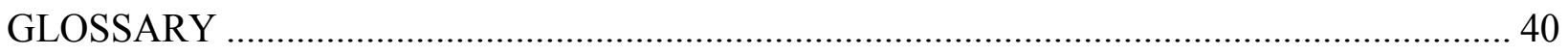

APPENDIX A: ELECTRONIC DATA CHANNELS ........................................................... 41

APPENDIX B. VID CHARACTERIZATION WITH RED IMPAC PROGRAMMERS: TEST-

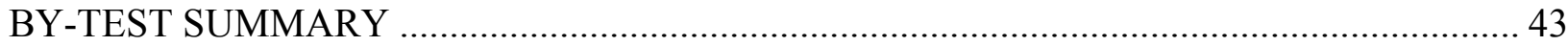

APPENDIX C: SAMPLE DATA SHEETS - RED URETHANE PROGRAMMERS ............... 53 
APPENDIX D. VID CHARACTERIZATION WITH FELT PROGRAMMERS (DENSITY

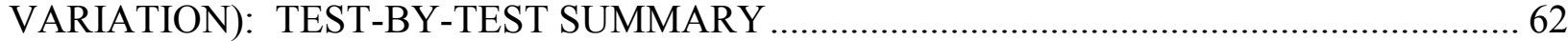

APPENDIX E: SAMPLE DATA SHEETS - FELT PROGRAMMERS (DENSITY

VARIATION)

APPENDIX F. VID CHARACTERIZATION WITH FELT PROGRAMMERS (THICKNESS

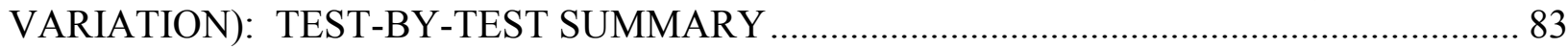

APPENDIX G: SAMPLE DATA SHEETS - FELT PROGRAMMERS (THICKNESS

VARIATION) 


\section{LIST OF FIGURES}

Figure 1. $711^{\text {th }}$ HPW Vertical Impact Device ................................................................ 5

Figure 2. VID Configuration with Red Programmers ...................................................... 6

Figure 3. VID Set-up with Red Programmers (Top) and Felt Programmers (Bottom) .............. 7

Figure 4. Location of Three Tri-axial Accelerometer Arrays on Top of VID Table .................. 9

Figure 5. Phantom Miro-3 High-Speed Digital Camera .................................................... 11

Figure 6. Felt 16S1, 0.5 inch sample (Left) and Felt 20S1, 0.5 inch sample (Right) ............... 14

Figure 7. Felt 26S1, 0.5 inch sample (Left) and Felt 32S1, 0.5 inch sample (Right) ............... 14

Figure 8. Felt 20S1, 0.25 inch sample (Left), and Felt 20S1, 0.5 inch sample (Right) ............. 15

Figure 9. Felt 20S1, 1.0 inch sample (Left), and Felt 20S1, 2.0 inch sample (Right) .............. 16

Figure 10. Peak Acceleration as a Function of Drop Height - Red IMPAC Programmers ........ 18

Figure 11. Velocity Change as a Function of Drop Height - Red IMPAC Programmers .......... 18

Figure 12. Acceleration Profiles at Two Drop Heights - Red IMPAC Programmers ............... 20

Figure 13. Prediction Curve for Peak Acceleration - Red IMPAC Programmers .................... 20

Figure 14. Prediction Curve for Velocity Change - Red IMPAC Programmers ...................... 21

Figure 15. Peak Acceleration as a Function of Drop Height - Felt Density Variation .............. 23

Figure 16. Velocity Change as a Function of Drop Height - Felt Density Variation ................ 23

Figure 17. Acceleration Profiles at Two Drop Heights for Two Felt Density Samples ............ 26

Figure 18. Prediction Curve for Peak Acceleration - Felt Density 32S1 .............................. 27

Figure 19. Prediction Curve for Velocity Change - Felt Density 32S1 ................................ 27

Figure 20. Peak Acceleration as a Function of Drop Height - Felt Thickness Variation .......... 31

Figure 21. Velocity Change as a Function of Drop Height - Felt Thickness Variation ............ 31

Figure 22. Acceleration Profiles at Two Drop Heights for Two Felt Thickness Samples ......... 33

Figure 23. Prediction Curve for Peak Acceleration - Felt Thickness Variation ...................... 34

Figure 24. Prediction Curve for Velocity Change - Felt Thickness Variation ......................... 35 


\section{LIST OF TABLES}

Table 1. Test Matrix for Red IMPAC Programmer Characterization.................................... 12

Table 2. Test Matrix for Felt Programmer Characterization as a Function of Density ............. 13

Table 3. Test Matrix for Felt Programmer Characterization as a Function of Thickness.......... 15

Table 4. Red IMPAC Programmer Assessment: Data Summary Showing Means and Standard

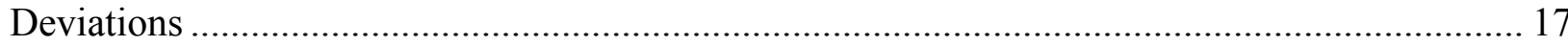

Table 5. Felt Programmer Assessment (Density Variation): Data Summary Showing Means and

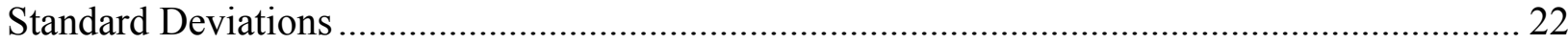

Table 6. Felt Programmer Assessment (Density Variation): Curve Fit Model.......................... 25

Table 7. Percent Difference in Peak Acceleration Relative to Felt 16S1 ............................... 28

Table 8. Percent Difference in Velocity Change Relative to Felt 16S1 ................................ 29

Table 9. Felt Programmer Assessment (Thickness Variation): Data Summary Showing Means

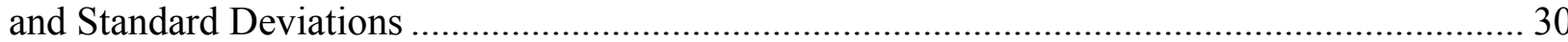

Table 10. Felt Programmer Assessment (Thickness Variation): Curve Fit Model................... 32

Table 11. Percent Difference in Peak Acceleration Relative to Felt Thickness ...................... 36

Table 12. Percent Difference in Velocity Change Relative to Felt Thickness........................... 36 


\section{ACKNOWLEDGMENTS}

The authors would like to thank the following people for their expertise and assistance during this study in helping to: develop and design test fixtures, install and calibrate instrumentation, set-up and run experiments, and collect and process data:

- Mr. Delane “Bull” Bullman, Mr. Greg Thompson, Mr. Glenn Thomas, Mr. Brian Grattan, Mr. Eric Master (Infoscitex Corporation)

- TSgt Clifford Hatch, TSgt James Chase, SSgt Doug Robson, and SrA Erik Black (Aircrew Biodynamics and Protection Team within the $711^{\text {th }}$ Human Performance Wing)

- Mr. Ben Steinhauer and Mr. Joseph Strzelecki (Aircrew Biodynamics and Protection Team within the $711^{\text {th }}$ Human Performance Wing) 


\subsection{OVERVIEW}

The Aircrew Biodynamics and Protection (ABP) Team of AFRL (711 HPW/RHCPT) and their in-house technical support contractor, Infoscitex, conducted a series of tests to identify the performance capabilities of the Vertical Impact Device (VID). The VID is a Monterey Research Laboratory IMPAC3636 high-G impact test machine with seismic suspension, and is currently situated at the 711 Human Performance Wing (HPW), Airman Systems Directorate in Bldg. 824 at Wright Patterson AFB, OH. The VID impact test machine is used to generate short duration, very high amplitude impact acceleration profiles to evaluate the effects on human and manikin subjects, and define the effectiveness of operational and prototype protection concepts, for the purpose of improving warfighter performance. The system can provide a maximum acceleration in excess of $1000 \mathrm{G}$ for very short durations, maximum velocity change of $50 \mathrm{ft} / \mathrm{s}(15.24 \mathrm{~m} / \mathrm{s})$, and pulse durations from 1 to approximately $30 \mathrm{~ms}$ in specific facility configurations.

The results provided in this report will be used as a reference for future test applications performed within the $711 \mathrm{HPW}$, as a benchmark for post-refurbishment and post-maintenance performance verification, and to potentially determine the degree of participation in the Army's Warrior Injury Assessment Manikin (WIAMan) development program. The test series characterized the VID acceleration profiles using a parametric assessment of VID urethane programmers, felt programmer thickness, and felt programmer density. 


\subsection{BACKGROUND}

One of the signature injuries identified with the war in the Middle East as more and more wounded soldiers return home is blast injuries. Blast injuries are caused by being in proximity to an explosive device when it detonates, and which have been seen previously but have been more closely documented on the battlefield since World War I (WWI). Improvements in body armor and better battlefield medicine is allowing more wounded soldiers to live and return home after suffering a blast injury. Military surgeons are being trained to better understand the pathology of blast injuries and spot the more subtle symptoms in patients enduring treatment. In the war in Iraq, Improvised Explosive Devices or better known as IEDs are the weapon of choice for insurgents and widely used against our soldiers. The IEDs can cause blast injuries that have the ability to cause compounded catastrophic injuries, as well as the less visually observed or hidden injuries related to brain trauma as a result of a blast wave. As a result, the Army initiated the WIAMan program.

The WIAMan program has the main objective to gain an understanding of the biomechanics of injuries that occur in a combat vehicle underbody blast event involving a landmine or improvised explosive device. This will be accomplished using the data generated during this program to fabricate a specialized manikin that will be used in military Live-Fire Test and Evaluation efforts for the development of injury criteria. The new injury criteria and the new manikin will then be used to develop and evaluate mitigation technologies for ground combat vehicle seating systems.

Previous research on the VID (Knox, T., Pellettiere, J., Perry, C., Plaga, J., Bonfeld, J., 2008; Veridian Contract Report, CDRL A005, 2002; and Salerno, Capt. M.D., Brinkley, J.W., Orzech, Capt. M.A., 1985) focused on application of an energy pulse to either a piece of equipment or a human subject to determine its biodynamic response. The energy pulse was defined by achievement of a maximum peak acceleration value. Very little if any work had been completed to relate the drop height of the VID to a range of acceleration values with a specified time-topeak (TTP).

Part of the approach for the WIAMan program will be to define the loading environment which produces the injuries being investigated. The defined loading environment will then be used to measure the applied loads and resultant injuries to test specimens and produce tissue properties, human injury tolerance and response corridors, and ultimately injury risk curves. This requirement to understand the blast loading environment led to the initiation of the $711 \mathrm{HPW}$ program to evaluate the impact pulse characteristics of the VID facility. 


\subsection{OBJECTIVES}

The initial performance requirements for the VID to support the WIAMan program were impact acceleration pulses over $300 \mathrm{G}$ with pulse time-to-peak values in the 5 to $10 \mathrm{~ms}$ range. The test program to determine the VID pulse characteristics using a parametric analysis pursued the following objectives:

(1) Evaluate the performance of the VID's high-density (red) urethane programmers as a function of progressively increasing drop heights of the VID drop table.

(2) Evaluate the performance of four different industrial felt densities of the same thickness as a function of progressively increasing drop heights of the VID drop table.

(3) Evaluate the performance of four different industrial felt thicknesses of the same felt density as a function of progressively increasing drop heights of the VID drop table. 


\subsection{TEST FACILITY AND EQUIPMENT}

\subsection{Vertical Impact Device}

The VID or IMPAC 3636 test machine was manufactured in the 1960's, and was given to the AFRL biodynamics facility from NASA. The VID is a high acceleration, shock testing machine capable of providing a maximum acceleration of $1000 \mathrm{G}$. It is capable of providing a maximum velocity change of $50 \mathrm{ft} / \mathrm{s}(15.24 \mathrm{~m} / \mathrm{s})$ and minimum pulse duration of 1.6 milliseconds. The maximum drop height is between 8 to 12 feet depending on the mounted test fixture. A test is performed by dropping the carriage supporting the test fixture onto a reaction mass.

The major components of this facility consist of the carriage, reaction mass, elastic programmers, lifting and braking system, and control console. The carriage is a single piece high-strength aluminum (7079-T6) forging with machined surfaces carefully designed to provide a uniform load distribution, and weighing $1300 \mathrm{lbs}$. Bronze bearings guide the carriage on two hard chrome-plated rails. The reaction mass is a $12,000-1 b$ forged steel block mounted on a critically damped, constant force, nitrogen and oil suspension system.

Programmers are used to control the shape, peak acceleration, and duration of the shock pulse. The programmers are mounted on the underside of the carriage or on the top of the reaction mass, and control the contact surface between the carriage and the reaction mass. Programmers can be combined in various configurations to provide specialized shock pulses. The carriage lifting system consists of a cable, pulley, and lifting tube driven by one hydraulic cylinder, for each of the two side supports. Pneumatic friction brakes in the carriage assembly clamp the carriage to the guide rails when the desired drop test height has been reached; the lifting tubes are then lowered to their pre-test position at the bottom of the rails. The carriage is released at test initiation by a fast-acting valve in the brake system. The brakes are again energized to stop any rebound of the carriage after the carriage impacts on the reaction mass. The control console contains all the switches and condition lights for the remote control of the facility. The console also houses the hydraulic power for the lifting system. The VID is shown in Figure 1.

In order to obtain a shock pulse of desired maximum acceleration and duration and to prevent damage to the shock test machine, it is necessary to place a programmer (shock-mitigating material) between the shock table and reaction base. This material has energy-absorbing characteristics, and typical programmers are constructed from felt or urethane materials. A third type of programmer, the universal programmer, uses pressurized air and is applicable for low accelerations. 


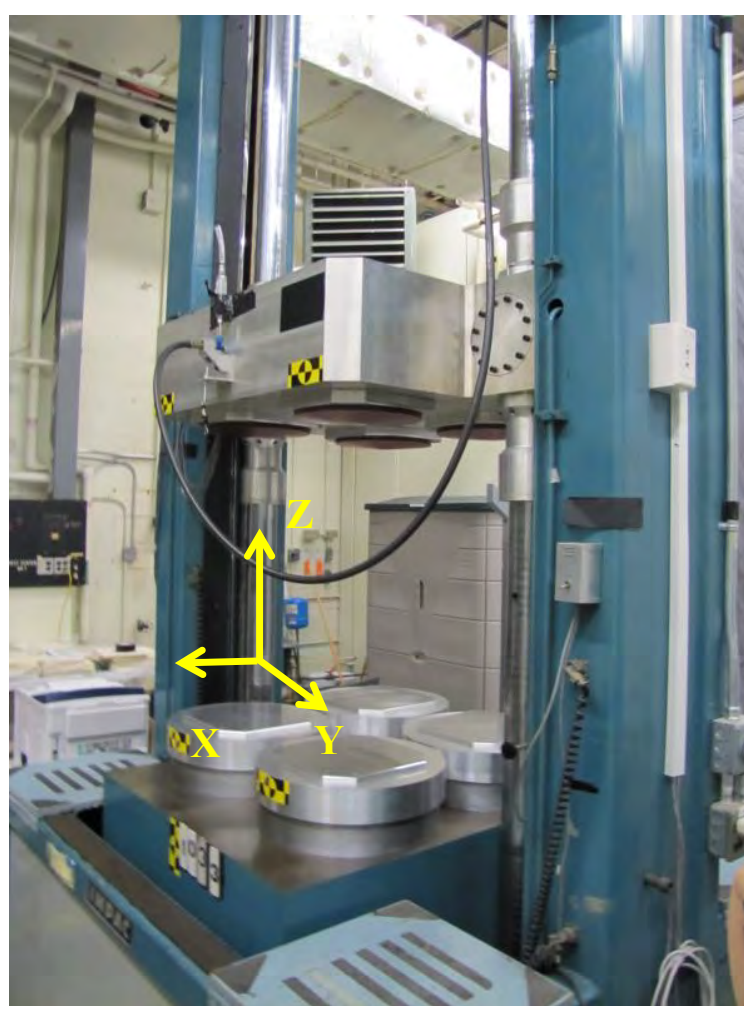

Figure 1. $711^{\text {th }}$ HPW Vertical Impact Device

\subsection{VID Configuration}

The VID evaluation was conducted using different configurations of programmers mounted in a four-square grid pattern on the either the bottom of the drop table, or on top of the reaction mass. No test fixture was mounted on the drop table for any of the tests in this phase. The reaction mass's suspension system was pressurized to 2000 psi. as directed by the IMPAC 3636 instruction manual.

The positive axis of the coordinate system for the test configuration for this program is defined with respect to the orientation of the manikin positioned in the seat mounted to the VID carriage. The coordinate system is shown for this test configuration in the Figure 1 above.

\subsection{Red IMPAC and Felt Programmers}

The test program approach used a parametric analysis with the objective to define and evaluate the performance effect of the different impact attenuators on VID impact acceleration. The energy attenuators consisted of the high-density red urethane or Red IMPAC programmers, and industrial felt of varying density and thickness. The concept of using felt was borrowed from the work of Childers (Childers, M.A. 2002). One red urethane programmer, 4 felt densities, and 4 felt thicknesses were evaluated, and were used as the basis to separate the data analysis into three sub-phases. 
The circular red urethane programmers, were each mounted to a $1 \mathrm{ft}^{2}, 0.25$ inch thick steel plate, had an approximate diameter of 11.75 inch, and an edge thickness of 0.5 inch. The programmer increased in thickness towards the center where it became a flat topped cone with an approximate diameter of 2.0 inch and a thickness of 0.94 inch at the center. Each red programmer impacted a flat, $1 \mathrm{ft}^{2}$ steel plate mounted to the top of the reaction mass as shown in Figure 2.

The felt programmer configurations were evaluated using different combinations of felt sample thickness and density that were positioned in a four square grid pattern on the top of the reaction masses' $1 \mathrm{ft}^{2}$ steel plates. This is shown in Figure 3. The felt samples were purchased from the Bacon Felt Company in Rochester, NH, and consisted of 1 sq. $\mathrm{ft}$. samples that varied in density and thickness. The densities covered the range from 16 to $32 \mathrm{lbs}$ as defined by Bacon Felt for a 3 $\mathrm{x} 3 \mathrm{ft}$. square sample that is 1.0 inch thick (the first two numbers of the felt's ID\# indicate the density of the material... 16S1, 20S1, 26S1, and 32S1). The sample thicknesses that were evaluated varied from 0.25 inch up to 2.0 inch. The tests of the effects of felt density were conducted with samples with a constant felt thickness of 0.5 inch. The tests of the effects of felt thickness were conducted with sample with a constant felt density of 20 lbs (Felt ID\# 20S1).

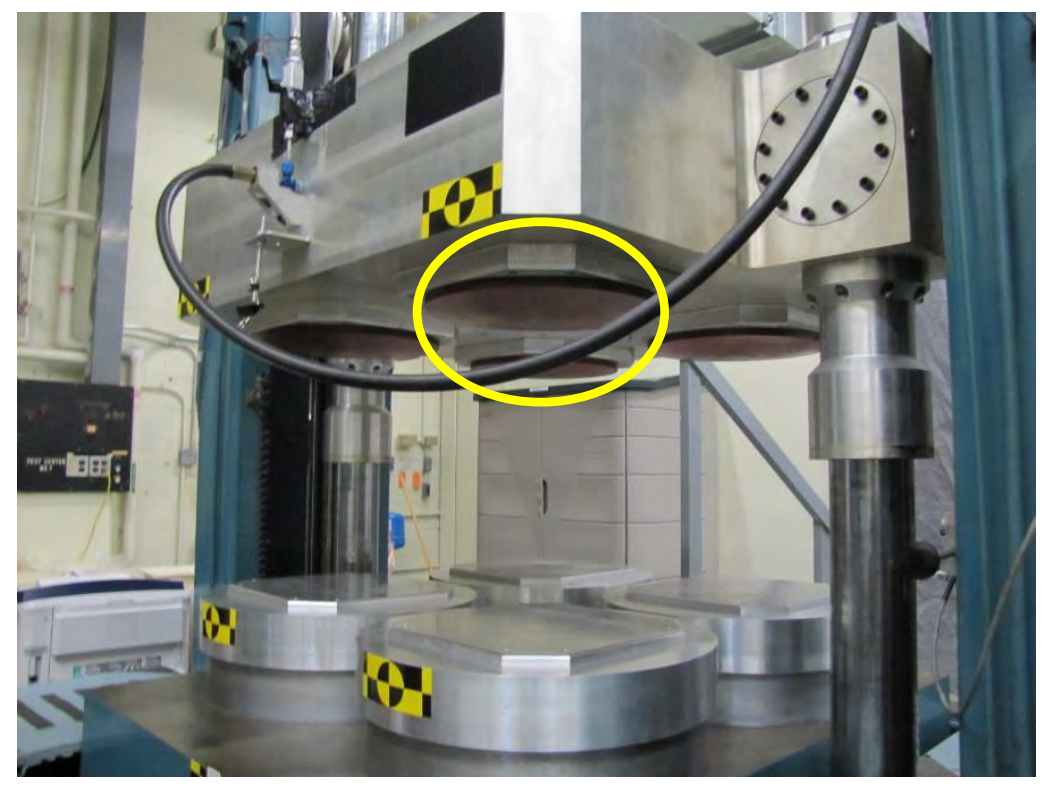

Figure 2. VID Configuration with Red Programmers 


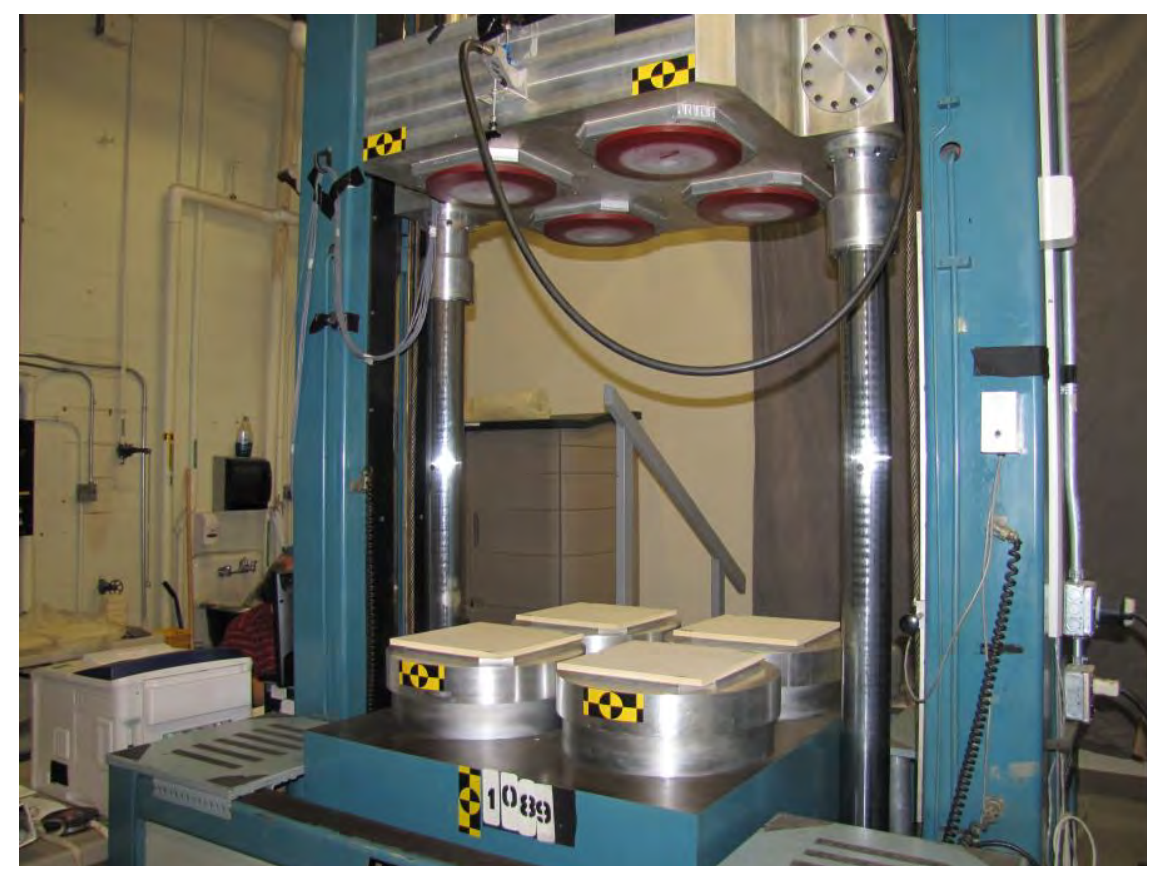

Figure 3. VID Set-up with Red Programmers (Top) and Felt Programmers (Bottom) 


\subsection{INSTRUMENTATION AND DATA COLLECTION}

Transducers were chosen to provide the optimum resolution over the expected test acceleration ranges. Full-scale data ranges were selected to provide the expected full-scale range plus $50 \%$ to assure the capture of peak signals. All transducer bridges were balanced for optimum output prior to the start of the program. The appropriate accelerometers were adjusted with software for the effect of gravity by adding the component of a $1 \mathrm{G}$ vector in-line with the force of gravity along the accelerometer axis.

The coordinate system (shown in Figure 1) used was the Right-Hand Rule with the z-axis parallel to the VID guide rails, and with positive being up towards the top of the VID facility. The $\mathrm{x}$-axis is perpendicular to the $\mathrm{z}$-axis and points outward away from the VID impact table. The $y$-axis is perpendicular to the $\mathrm{x}$ - and $\mathrm{z}$-axes according to the right-hand rule. The linear accelerometers were wired to provide a positive output voltage when the acceleration experienced by the accelerometer was applied in the $+\mathrm{x},+\mathrm{y}$ and $+\mathrm{z}$ directions.

\subsection{Facility Instrumentation}

Acceleration measurements were taken on the VID at three different reference point locations on the top surface of the carriage or drop table (shown in Figure 4). One reference point was located at the geometric center of the table, and the second and third at points close to the tables two guide rails (within 2 inches from outer curvature of either rail). The accelerometer package was a tri-axial array consisting of three linear accelerometers mounted in each of the three coordinate axes.

The tri-axial accelerometer package mounted at the geometric center of the table was composed of two Entran Model 7264C-500 accelerometers mounted in the $\mathrm{x}$ and $\mathrm{y}$-axis, and a single MEAS EGCS-1000-S425 accelerometer mounted in the z-axis. The tri-axial accelerometer packages mounted at the points on the table, close to the table's guide rails, were composed of two Entran Model 7264C-500 accelerometers mounted in the $\mathrm{x}$ and $\mathrm{y}$-axis, and a single MEAS EGCS-1000-S425 accelerometer mounted in the z-axis. 


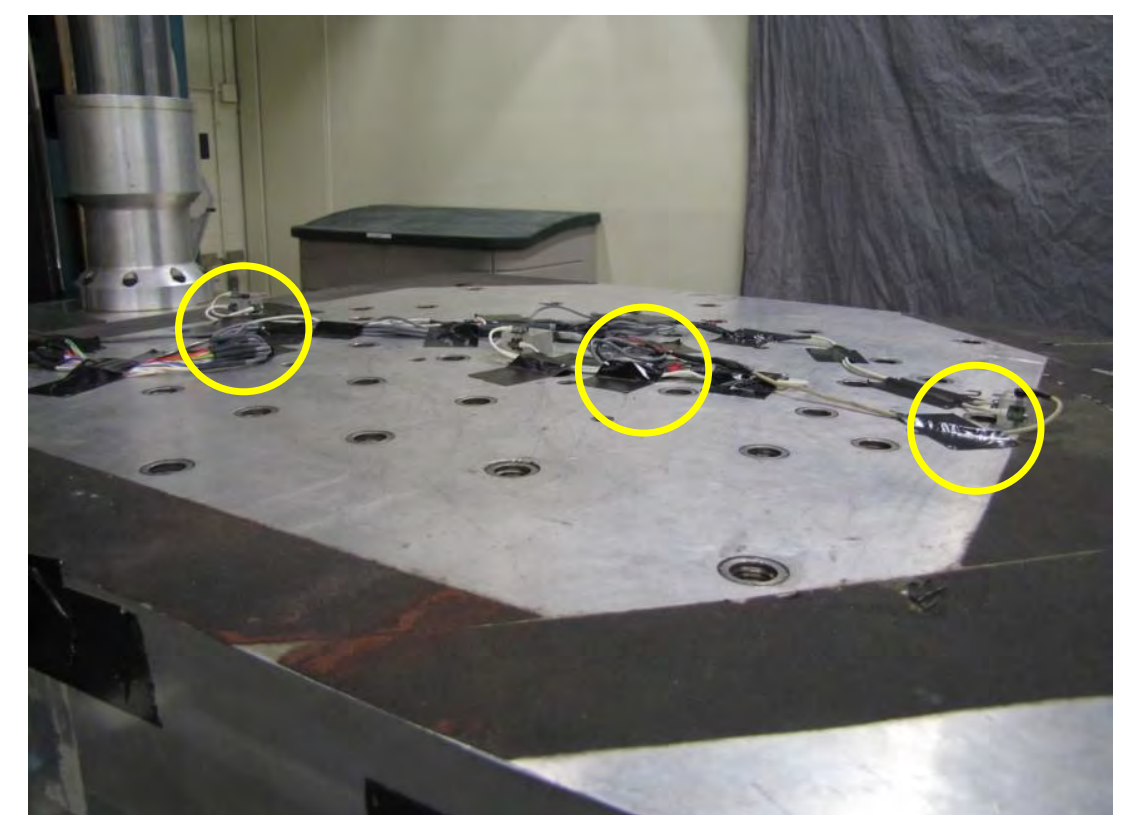

Figure 4. Location of Three Tri-axial Accelerometer Arrays on Top of VID Table

\subsection{Transducer Calibration}

On-site personnel from Infoscitex, Inc. conducted pre- and post-calibrations on all sensors used on the carriage and seat fixture. Calibration records of individual transducers as well as the Standard Practice Instructions are maintained in the biodynamic facility's Impact Information Center. For this test program, a record was made identifying the data channel, transducer manufacturer, model number, serial number, date and sensitivity of pre-calibration, date and sensitivity of post-calibration, and percentage change. Pre- and post-calibration information is maintained with the program data. The instrumentation used in this study is listed in the Electronic Instrumentation Data Sheet (See Appendix A.).

\subsection{Data Acquisition Control}

The data collection process was controlled by a technician seated at the VID's Master Station Control located on the side of the VID facility. A test was initiated when the technician initiated a verbal countdown. The technician then initiated the data collection and the video collection with separate hand-held switches at $\mathrm{t}=-2 \mathrm{sec}$. Software was used to establish a zero reference for all transducers prior to table impact.

\subsection{Data Acquisition System}

Transducer excitation, signal amplification, filtering, digitizing, and transmission was provided off-board the VID carriage by a computer-controlled data acquisition system (DAS). This research program used the TDAS G5 DAS manufactured by Diversified Technical Systems (DTS), Inc., to collect all the fixture data for each test as defined by the test matrix. The 32channel TDAS G5 was mounted off-board the VID next to the Master Station Control laptop. 
The TDAS G5 is a ruggedized, DC powered, fully programmable signal conditioning and recording systems for transducers and events. The TDAS G5 was designed to withstand a $100 \mathrm{G}$ shock.

The signal conditioning accepts a variety of transducers including full and partial bridges, voltage, and piezo-resistive sensors. Transducer signals are amplified, filtered, digitized and recorded in onboard solid-state memory. The data acquisition system is controlled through an Ethernet interface using the Ethernet instruction language. A laptop PC with an Ethernet board configures the TDAS G5 before testing and retrieves the data after each test. For this program, the DAS collected data at a $20 \mathrm{~K}$ sample rate with a $2 \mathrm{KHz}$ anti-aliasing filter.

\subsection{Quick Look Data Plots}

After each test, the filtered data were graphically plotted in a portrait format of 4-6 plots per page, and grouped with similar channels. The spreadsheet of plots also contained pertinent maxima, minima, and respective times of each occurrence. For all data, time $=0$ was at initial carriage motion. The plots arranged in this fashion included: displacement versus time, force (load) versus time, and acceleration versus time.

\subsection{High Speed Video and Photography}

Two Phantom Miro-3 High-Speed digital cameras (Figure 5) were used to collect video of each test. The cameras were mounted off-board the VID facility at perpendicular and oblique angles relative to the front of the facility (as shown in Figures 1 thru 3).

The Phantom Micro line is a compact, light-weight, rugged family of cameras targeted at industrial applications ranging from biometric research to automotive crash testing. Rated to survive $100 \mathrm{G}$ acceleration, this rugged camera can take 512 x 512 images at up to 2200 framesper-second (fps). Reduce the resolution to $32 \times 32$ and achieve frame rates greater than 95,000 fps. With an ISO rating of 4800 (monochrome, saturation-based ISO 12232), the camera has the light sensitivity for the most demanding applications. With shutter speeds as low as 2 microseconds, the user can freeze objects in motion, eliminate blur, and bring out the image detail needed for successful motion analysis. The camera accepts any standard 1" C-mount lens. The Phantom Miro-3 member of the family is optimized for applications such as Hydraulically Controlled, Gas Energized (HYGE) crash simulations used in the automotive industry.

Selectable 8-, 10- or 12-bit pixel depth allows the user to choose the dynamic range that best meets the demands of the application. The Miro-3 has a number of external control signals allowing for external triggering, camera synchronization, and time-stamping. The camera has both dynamic RAM and internal flash memory for non-volatile storage. Internal battery power allows the camera to be used in an un-tethered mode and ensures data survivability in case of loss of power.

The images for this study were collected at 1000 frames per second (fps). The video files were downloaded and converted to AVI format, and stored in the RH Collaborative Biomechanics 
Data Bank. Photographs were taken of the test set-up prior to each test. Photographic and video data were stored on an internal network for downloads as requested.

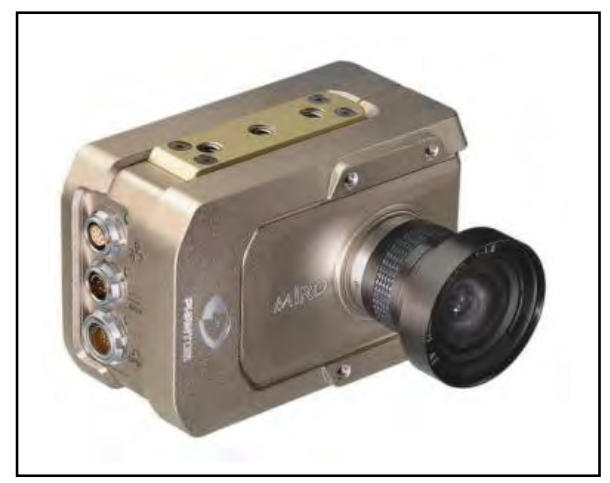

Figure 5. Phantom Miro-3 High-Speed Digital Camera 


\subsection{EXPERIMENTAL DESIGN}

Specially designed test matrices were developed to address the program objectives assessing the effects of increased drop heights on the VID table's acceleration response as a function of either the VID's red urethane programmers, or various combinations of high-density felt thickness and density.

\subsection{Red IMPAC Programmer Characterization}

The parametric evaluation of the red urethane used four programmers mounted in a four-square grid pattern on the bottom of the drop table. The red programmers each impacted a flat, 1 square foot, 0.25 inch thick, steel plate mounted to the top of the reaction mass as shown in Figure 2. The test matrix for this test series is shown in Table 1.

Table 1. Test Matrix for Red IMPAC Programmer Characterization

\begin{tabular}{|c|c|c|}
\hline Test Cell & $\begin{array}{c}\text { Drop Height } \\
\text { (in.) }\end{array}$ & Programmer \\
\hline \hline A & 5 & Red Disk \\
\hline B & 10 & Red Disk \\
\hline C & 15 & Red Disk \\
\hline D & 20 & Red Disk \\
\hline E & 25 & Red Disk \\
\hline F & 30 & Red Disk \\
\hline G & 40 & Red Disk \\
\hline H & 50 & Red Disk \\
\hline
\end{tabular}




\subsection{Felt Programmer Characterization}

The parametric evaluation of the felt samples also had them positioned in a four-square grid pattern, but on the top of the impact table. As indicated previously, the felt samples consisted of $1 \mathrm{ft}^{2}$ samples that varied in density and thickness. The densities ranged from 16 to $32 \mathrm{lbs}$ (based on 1.0 inch thick, square sample that was $3 \times 3 \mathrm{ft}$., and this density is indicated by the first two numbers of the sample ID). The sample thicknesses varied from $0.25 \mathrm{inch}$ up to $2.0 \mathrm{inch}$. The tests of the effects of felt density were conducted with a felt thickness of 0.5 inch. The tests of the effects of felt thickness were conducted with a felt density of $20 \mathrm{lbs}$. The parametric evaluations were conducted per the test matrices shown in Table 2 and 3. The density variation set-ups are shown in Figures 6 and 7, and the thickness variation set-ups are shown in Figures 8 and 9 .

Table 2. Test Matrix for Felt Programmer Characterization as a Function of Density

\begin{tabular}{|c|c|c|c|}
\hline Test Cell & $\begin{array}{c}\text { Drop Height } \\
\text { (in.) }\end{array}$ & Programmer & $\begin{array}{c}\text { Felt Density } \\
\text { (ID \#) }\end{array}$ \\
\hline \hline $\mathrm{I}$ & 10 & Red Disk/Felt & $16 \mathrm{~S} 1$ \\
\hline $\mathrm{J}$ & 10 & Red Disk/Felt & $20 \mathrm{~S} 1$ \\
\hline $\mathrm{K}$ & 10 & Red Disk/Felt & $26 \mathrm{~S} 1$ \\
\hline $\mathrm{L}$ & 10 & Red Disk/Felt & $32 \mathrm{~S} 1$ \\
\hline $\mathrm{M}$ & 40 & Red Disk/Felt & $16 \mathrm{~S} 1$ \\
\hline $\mathrm{N}$ & 40 & Red Disk/Felt & $20 \mathrm{S1}$ \\
\hline $\mathrm{O}$ & 40 & Red Disk/Felt & $26 \mathrm{~S} 1$ \\
\hline $\mathrm{P}$ & 40 & Red Disk/Felt & $32 \mathrm{~S} 1$ \\
\hline
\end{tabular}



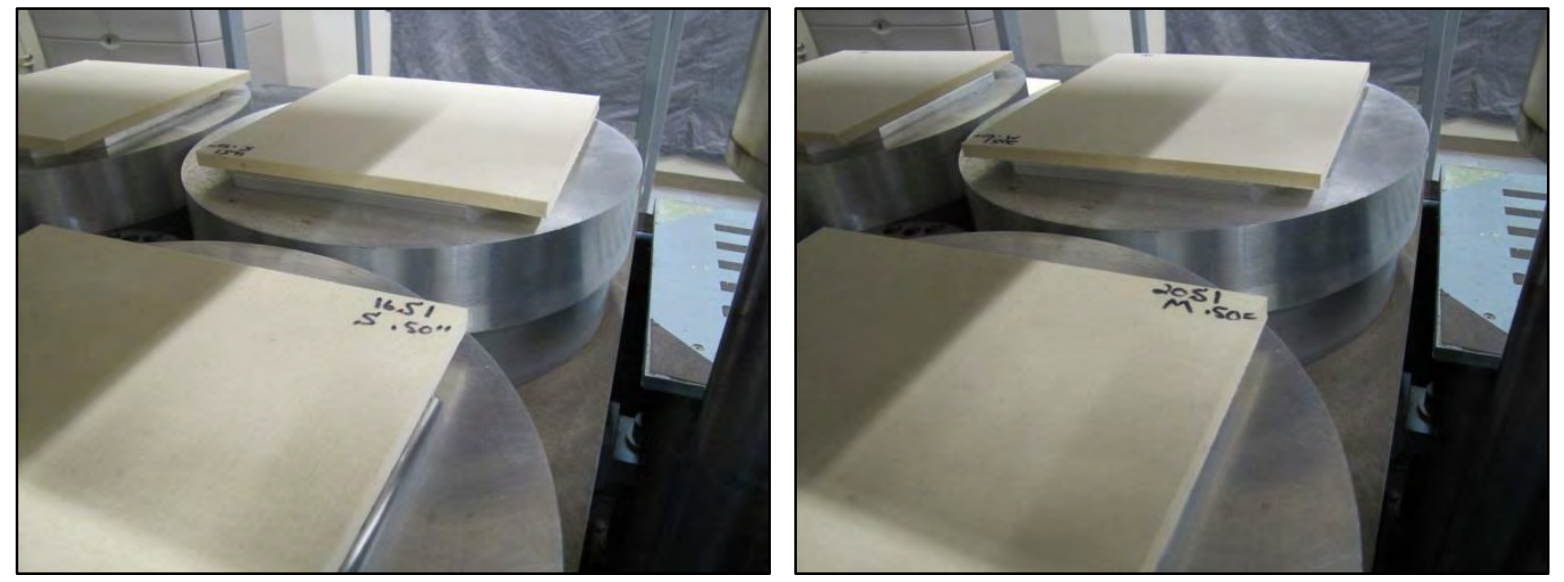

Figure 6. Felt 16S1, 0.5 inch sample (Left) and Felt 20S1, 0.5 inch sample (Right)
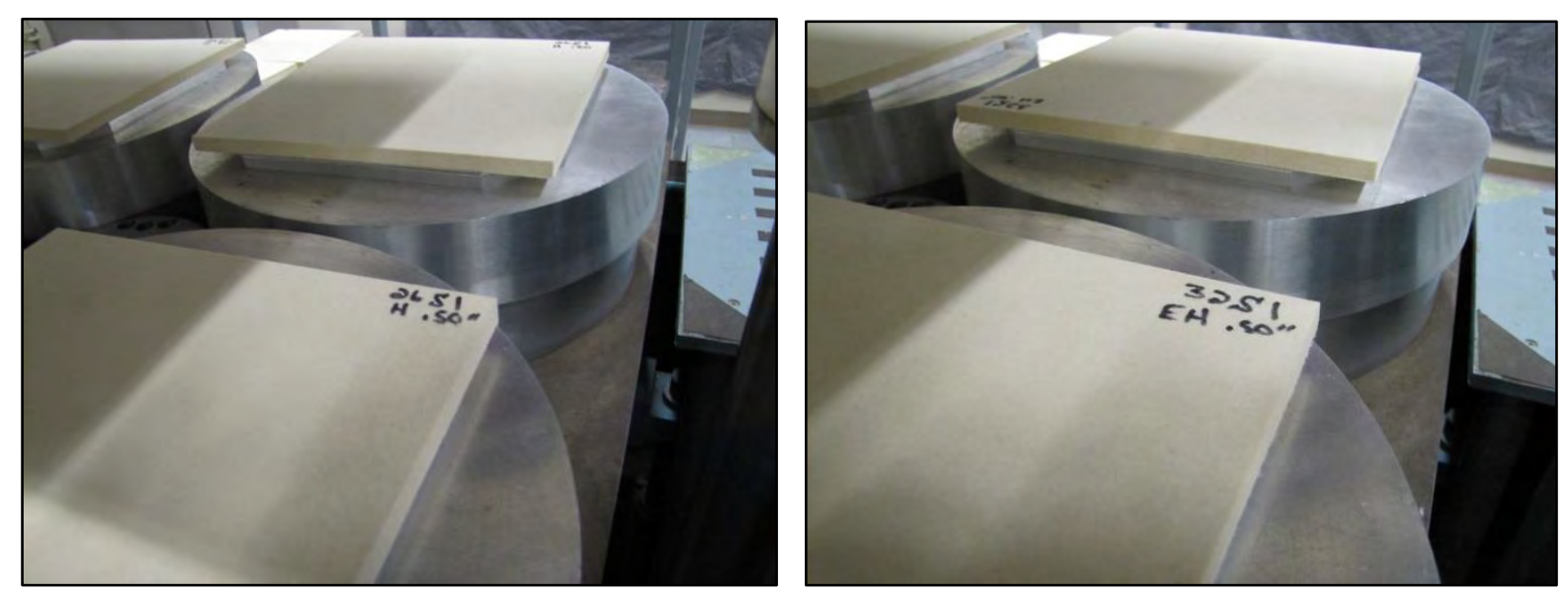

Figure 7. Felt 26S1, 0.5 inch sample (Left) and Felt 32S1, 0.5 inch sample (Right) 
Table 3. Test Matrix for Felt Programmer Characterization as a Function of Thickness

\begin{tabular}{|c|c|c|c|}
\hline Test Cell & $\begin{array}{c}\text { Drop Height } \\
\text { (in.) }\end{array}$ & Programmer & $\begin{array}{c}\text { Felt Thickness } \\
\text { (in.) } \\
\text { (Felt ID \#20S1) }\end{array}$ \\
\hline \hline $\mathrm{Q}$ & 10 & Red Disk/Felt & 0.25 \\
\hline $\mathrm{R}$ & 10 & Red Disk/Felt & 0.50 \\
\hline $\mathrm{S}$ & 10 & Red Disk/Felt & 1.00 \\
\hline $\mathrm{T}$ & 10 & Red Disk/Felt & 2.00 \\
\hline $\mathrm{U}$ & 40 & Red Disk/Felt & 0.25 \\
\hline $\mathrm{V}$ & 40 & Red Disk/Felt & 0.50 \\
\hline $\mathrm{W}$ & 40 & Red Disk/Felt & 1.00 \\
\hline $\mathrm{X}$ & 40 & Red Disk/Felt & 2.00 \\
\hline
\end{tabular}
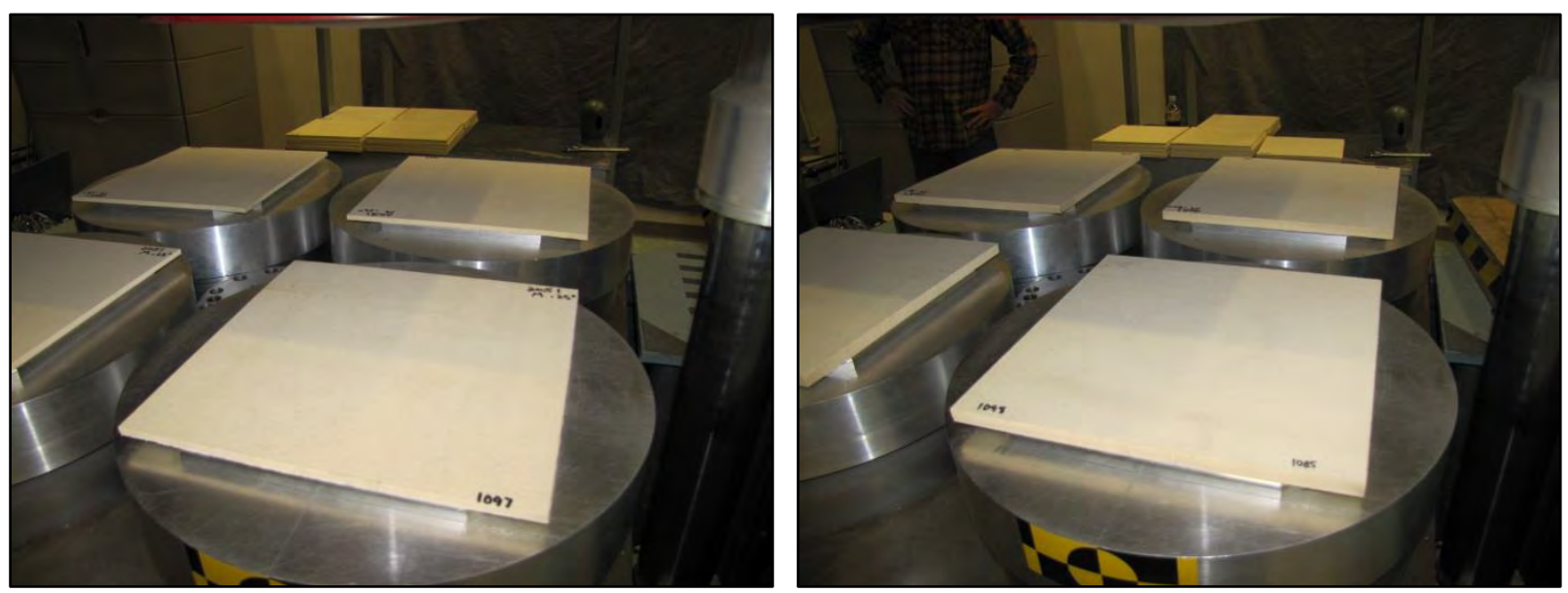

Figure 8. Felt 20S1, 0.25 inch sample (Left), and Felt 20S1, 0.5 inch sample (Right) 

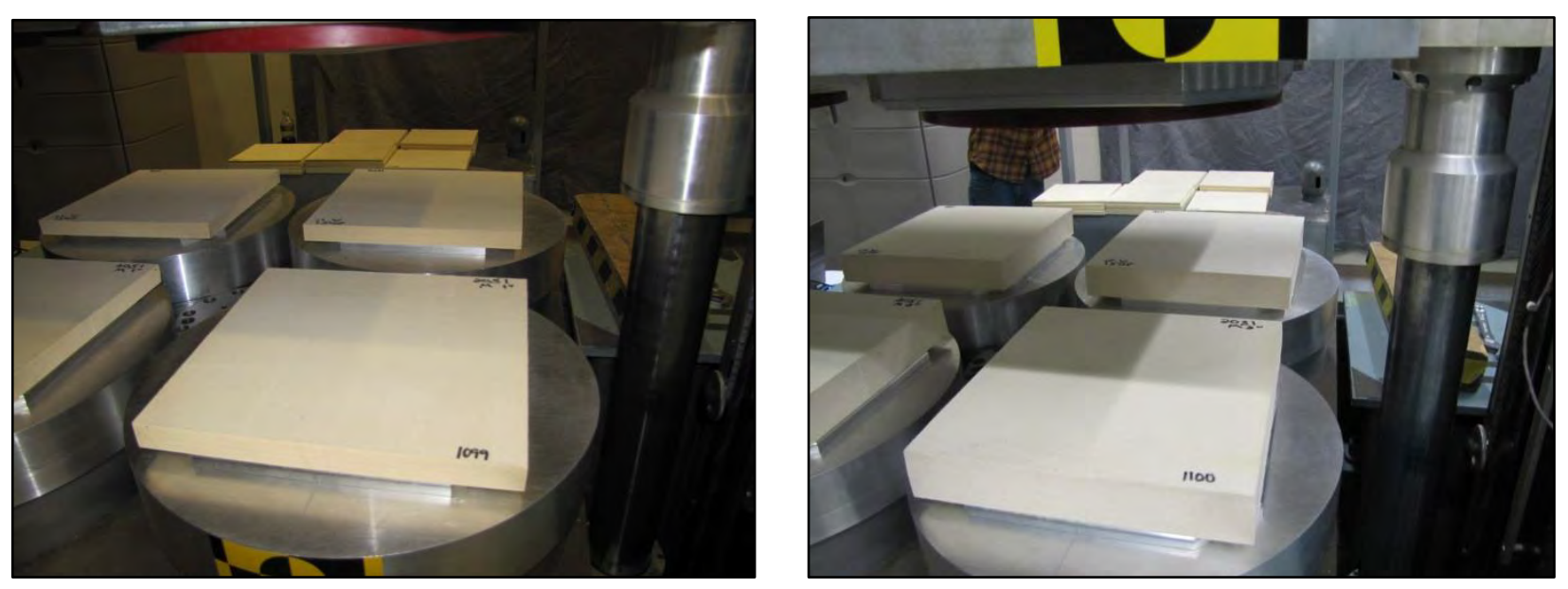

Figure 9. Felt 20S1, 1.0 inch sample (Left), and Felt 20S1, 2.0 inch sample (Right) 


\subsection{RESULTS}

A total of 97 impact tests were completed on the VID in support of this effort to characterize the acceleration pulses generated by the VID carriage as a function of the impact programmer. This phase of testing consisted of altering the drop height to observe the effects on peak acceleration, velocity change and other variables with the Red IMPAC Programmers in Test 1015-1079 and also with the addition of different felt densities and thicknesses in Test 1080-1112.

\subsection{Red IMPAC Programmer: Test-by-Test Summary}

A review of the specific test configuration for each of the red urethane impact tests conducted on the VID is shown with a test-by-test summary documenting test conditions and a brief summary of the key data. This is shown in Appendix B.

\subsection{Red IMPAC Programmer: Test Data Review}

The data collected from testing the red IMPAC programmers is presented in Table 4, and corresponds with Table 1 in the methods section. Table 4 used only subsets of the data at given drop heights for the statistical calculations. Both the resulting peak acceleration and integrated velocity change were able to be plotted as a function of progressively increasing drop heights, shown in Figures 10 and 11. Examples of the red programmer data plots generated after each test, via the post-test "quick-looks", is shown in Appendix C.

Table 4. Red IMPAC Programmer Assessment: Data Summary Showing Means and Standard Deviations

\begin{tabular}{|c|c|c|c|}
\hline Test Cell & $\begin{array}{c}\text { Drop Ht. } \\
\text { (in) }\end{array}$ & $\begin{array}{c}\text { Mean Peak Acceleration } \\
\text { (G) }\end{array}$ & $\begin{array}{c}\text { Mean Velocity } \\
\text { (ft/s) }\end{array}$ \\
\hline \hline A & 5 & $75.01 \pm 3.70$ & $6.16 \pm 0.17$ \\
\hline B & 10 & $120.07 \pm 0.41$ & $8.40 \pm 0.03$ \\
\hline C & 15 & $173.53 \pm 4.38$ & $10.34 \pm 0.16$ \\
\hline D & 20 & $216.55 \pm 3.72$ & $11.76 \pm 0.14$ \\
\hline E & 25 & $273.83 \pm 4.55$ & $13.24 \pm 0.14$ \\
\hline F & 30 & $295.21 \pm 10.02$ & $14.17 \pm 0.24$ \\
\hline G & 40 & $380.84 \pm 3.19$ & $16.42 \pm 0.40$ \\
\hline H & 50 & $441.94 \pm 11.89$ & $18.47 \pm 0.26$ \\
\hline
\end{tabular}




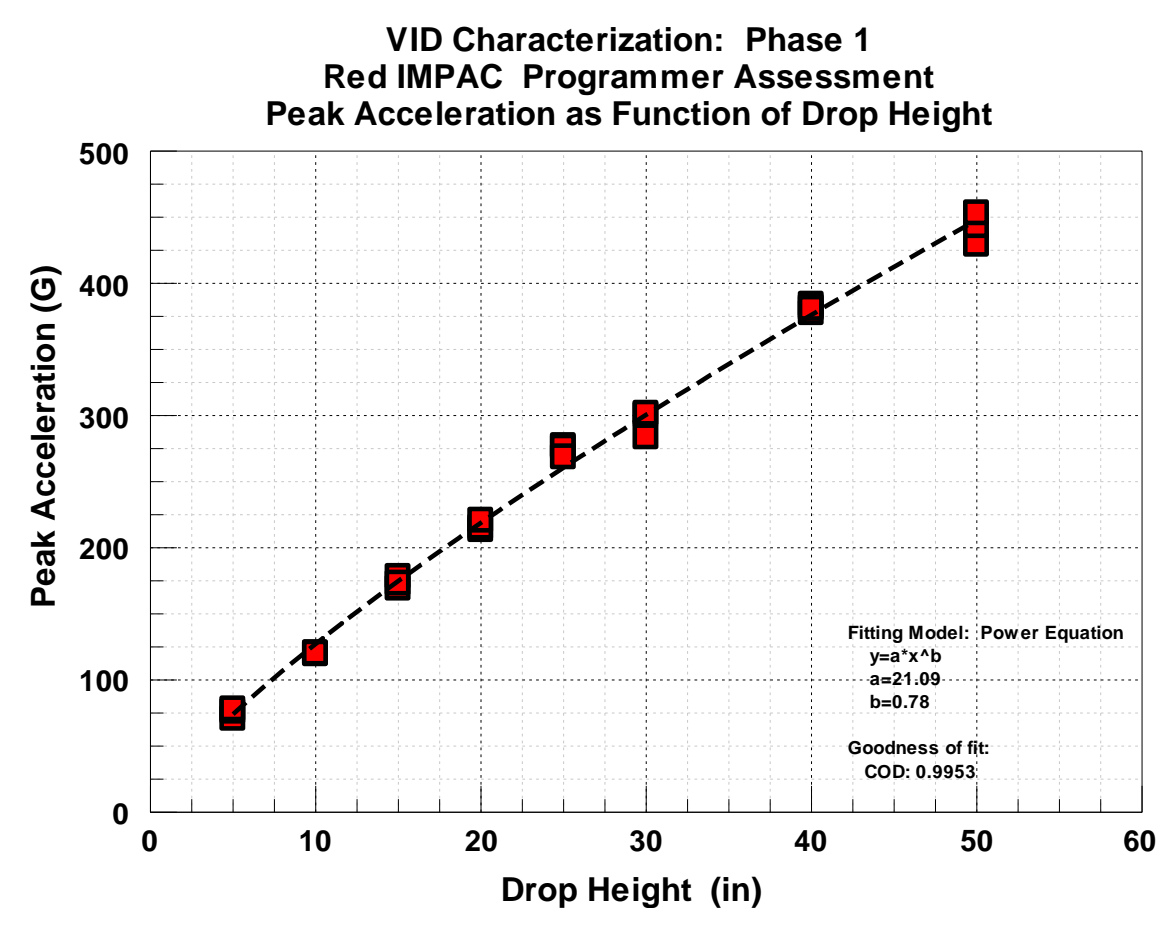

Figure 10. Peak Acceleration as a Function of Drop Height - Red IMPAC Programmers

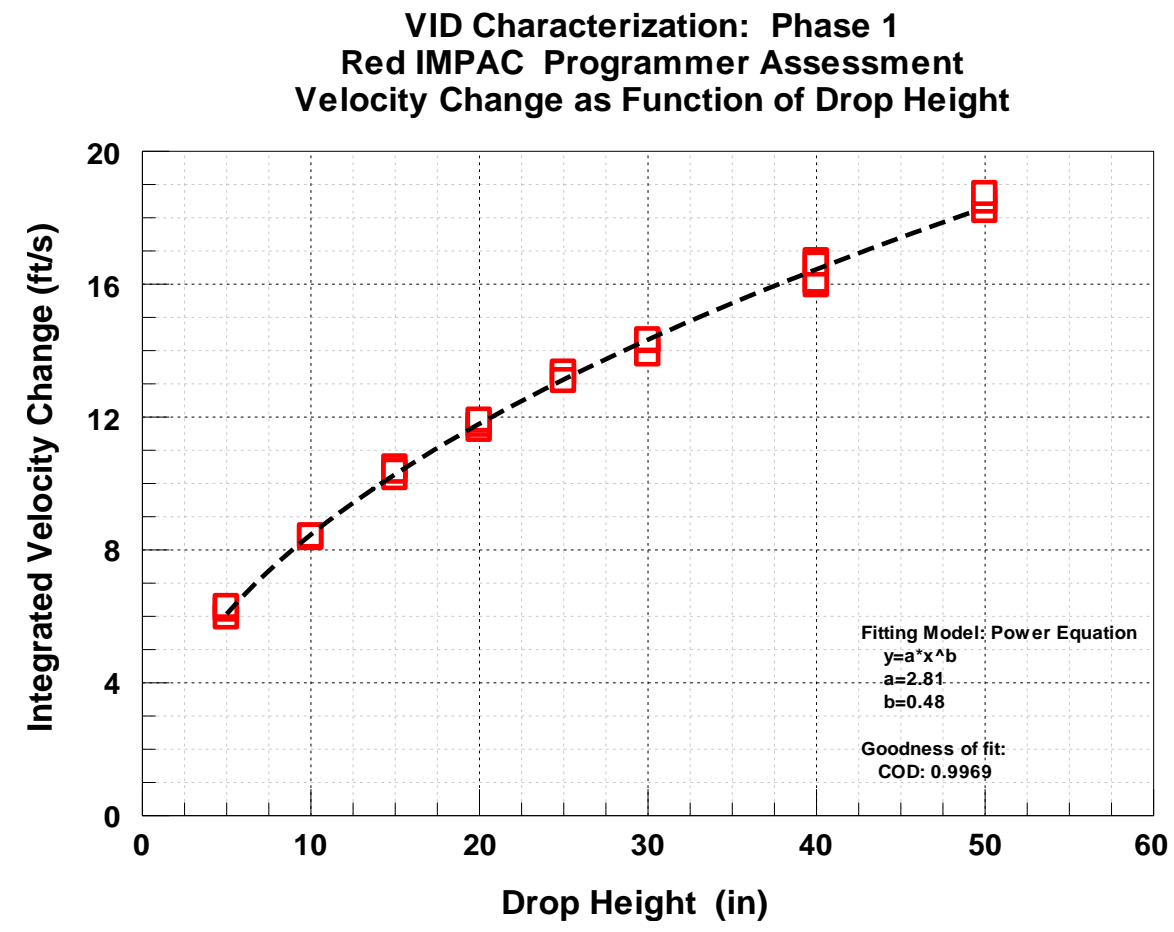

Figure 11. Velocity Change as a Function of Drop Height - Red IMPAC Programmers 
The data used to calculate the statistical means and standard deviations, for both the acceleration and calculated velocity change data sets, was composed of data from VID tests 1046 through 1070 that used accelerometer packages composed of new accelerometers. The other test data was not used due to inconsistencies with the original accelerometer package, or due to the addition of weight $(250 \mathrm{lb})$ added to the top the carriage. The added weight increased the acceleration measurements between 5 to $10 \%$, therefore, this data was not used in the statistical calculations. The narrow standard deviation values highlight the repeatability of the VID test facility.

The plots generated from test data showed that a Power Series equation provided the best fit regression line. The peak impact acceleration as a function of drop height was fit with a Power Series equation defined as $y=21.09^{*} x^{0.78}$, which provided a Coefficient of Determination (COD) of $r^{2}=0.9953$. The calculated peak velocity change as a function of drop height was also fit with a Power Series defined as $y=2.81^{*} x^{0.48}$, which provided a COD of $r^{2}=0.9969$. The excellent COD values for the two data sets also highlight the repeatability of the VID test facility, and also provides a tool for estimation of required test parameters.

The time history data from the two different test cells at the extreme of the test conditions (Cell A: 5 inch drop height, and Cell H: 50 inch drop height) were used to plot the generated impact acceleration profile as a function of time. The two waveforms show the variation in pulse width as the drop height increases (Figure 12). The acceleration pulse width can also be used as an estimator of the time-to-peak velocity which is the area under the acceleration curve, which can be seen to decrease from approximately $5.5 \mathrm{~ms}$ to $3.0 \mathrm{~ms}$ as the drop height increased from 5 inches to 50 inches.

The regression lines identified in Figures 10 and 11 for the acceleration and velocity response as a function of drop height were individually plotted to provide prediction curves. This was done to determine the values for peak acceleration and maximum velocity change at the current maximum drop height of the VID facility which is approximately 80 inches. The prediction curves are shown in Figures 13 and 14, and show a peak acceleration of approximately $650 \mathrm{G}$, and a maximum velocity change of approximately $23 \mathrm{ft} / \mathrm{s}$, at a drop height of 80 inches. 


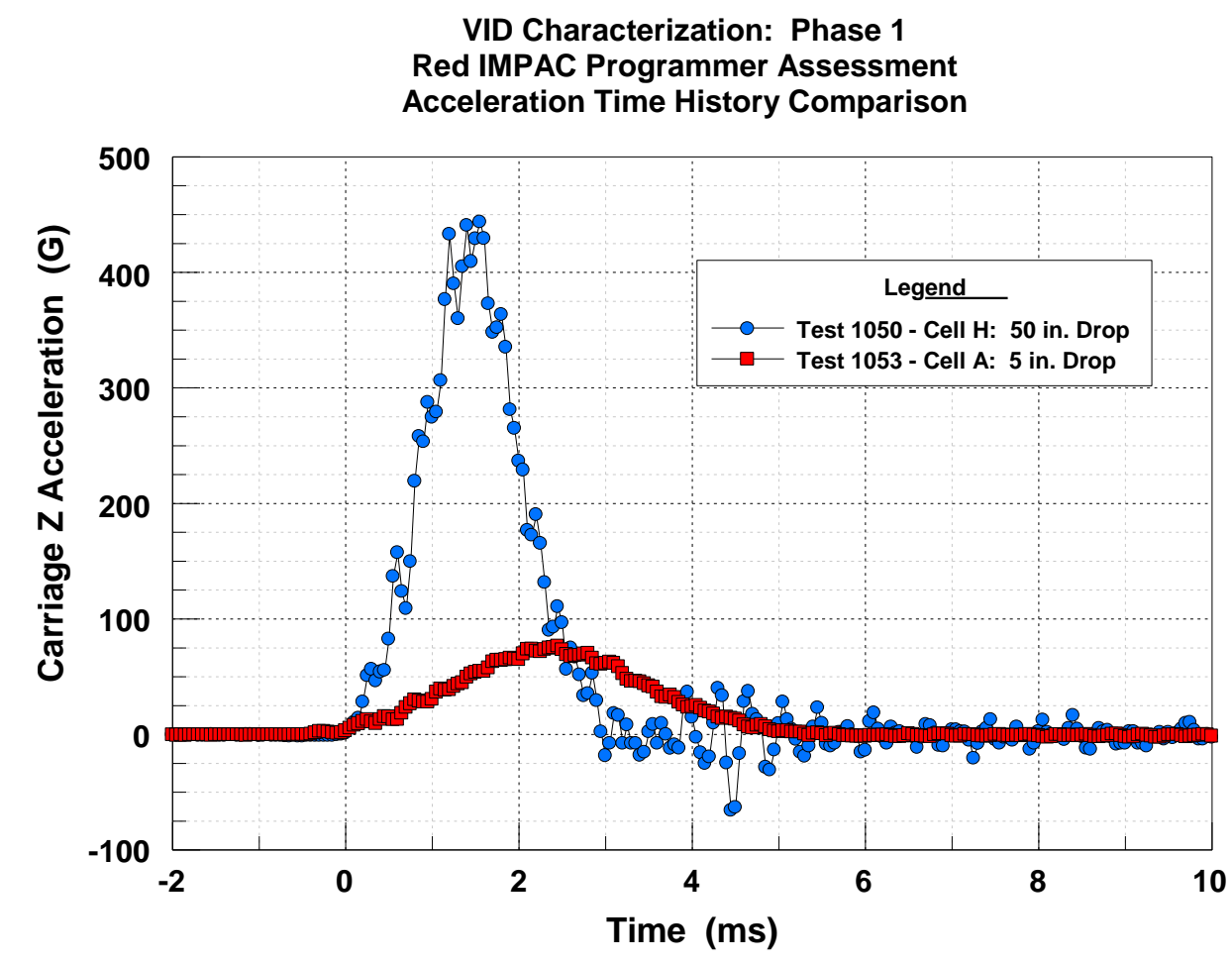

Figure 12. Acceleration Profiles at Two Drop Heights - Red IMPAC Programmers

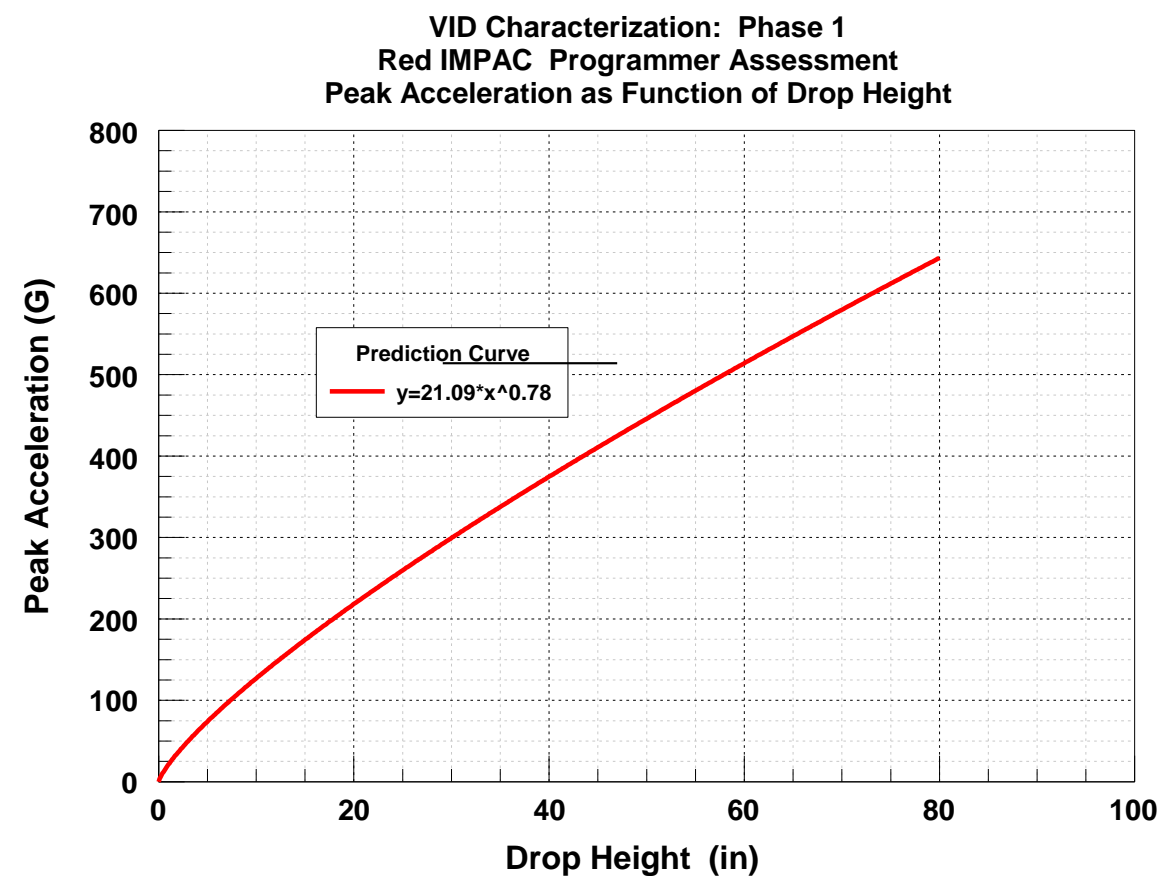

Figure 13. Prediction Curve for Peak Acceleration - Red IMPAC Programmers 


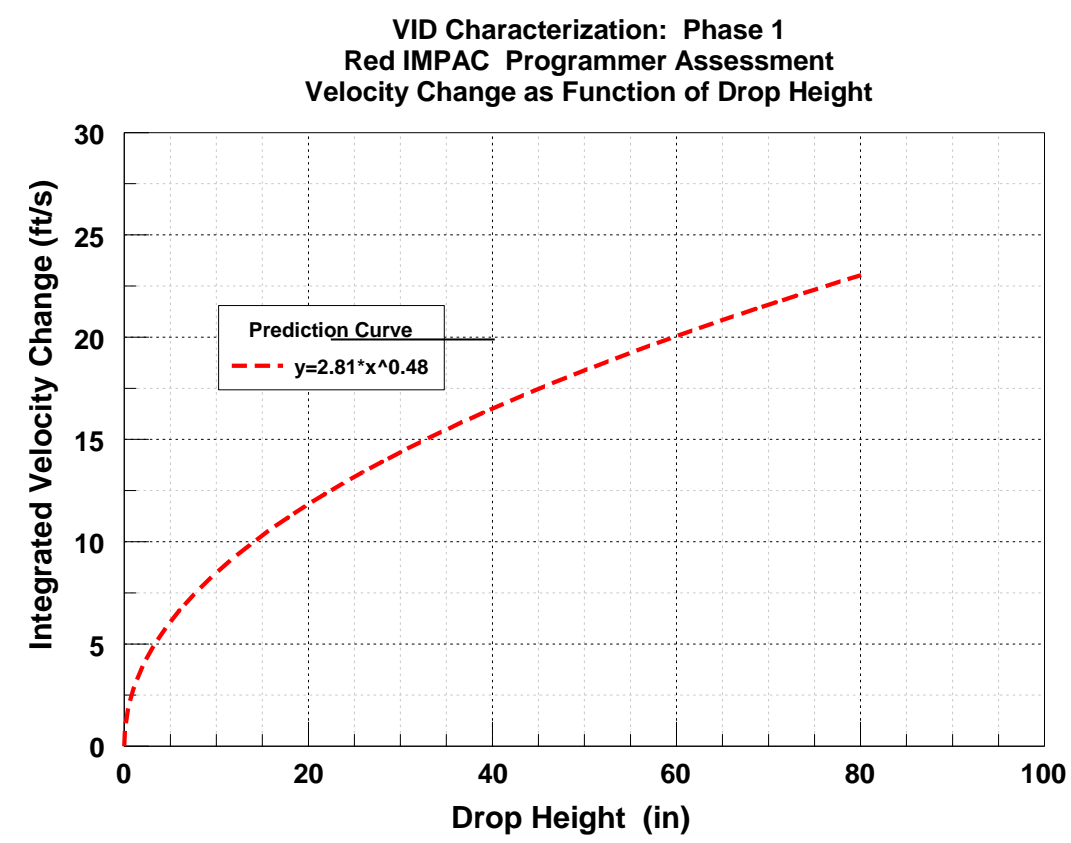

Figure 14. Prediction Curve for Velocity Change - Red IMPAC Programmers

\subsection{Felt Programmer (Density Variation): Test-by-Test Summary}

A review of the specific test configuration for each of the tests conducted on the VID with different felt programmer configurations, that varied by felt density, is shown with a test-by-test summary documenting the test conditions and a brief summary of the key data. This is shown in Appendix D.

\subsection{Felt Programmer (Density Variation): Test Data Review}

The data collected from testing the different felt samples that varied in density is presented in Table 5, and corresponds with the test parameters proposed in Table 2 in the methods section. Table 5 used all of the data at given drop heights for the statistical calculations. Both the resulting peak acceleration and integrated velocity change were able to be plotted as a function of progressively increasing drop heights, shown in Figures 15 and 16. Examples of the felt programmer data plots generated after each test, via the post-test "quick-looks", is shown in Appendix E. 
Table 5. Felt Programmer Assessment (Density Variation): Data Summary Showing Means and Standard Deviations

\begin{tabular}{|c|c|c|c|c|}
\hline Test Cell & $\begin{array}{c}\text { Drop } \\
\text { Height } \\
\text { (in) }\end{array}$ & $\begin{array}{c}\text { Felt } \\
\text { Density } \\
\text { (lb/yd } \mathbf{~}^{\text {(in }}\end{array}$ & $\begin{array}{c}\text { Mean Peak } \\
\text { Acceleration } \\
\text { (G) }\end{array}$ & $\begin{array}{c}\text { Mean } \\
\text { Velocity } \\
\text { (ft/s) }\end{array}$ \\
\hline \hline I & $\mathbf{1 0}$ & $\mathbf{1 6}$ & $68.33 \pm 3.34$ & $7.96 \pm 0.10$ \\
\hline $\mathbf{J}$ & $\mathbf{1 0}$ & $\mathbf{2 0}$ & $74.71 \pm 3.47$ & $8.10 \pm 0.12$ \\
\hline K & $\mathbf{1 0}$ & $\mathbf{2 5}$ & $75.72 \pm 2.78$ & $8.19 \pm 0.11$ \\
\hline $\mathbf{L}$ & $\mathbf{1 0}$ & $\mathbf{3 2}$ & $86.56 \pm 2.23$ & $8.43 \pm 0.05$ \\
\hline $\mathbf{M}$ & $\mathbf{4 0}$ & $\mathbf{1 6}$ & $249.11 \pm 13.10$ & $16.04 \pm 0.20$ \\
\hline $\mathbf{N}$ & $\mathbf{4 0}$ & $\mathbf{2 0}$ & $261.25 \pm 10.92$ & $16.17 \pm 0.13$ \\
\hline $\mathbf{O}$ & $\mathbf{4 0}$ & $\mathbf{2 5}$ & $259.54 \pm 16.43$ & $16.22 \pm 0.13$ \\
\hline $\mathbf{P}$ & $\mathbf{4 0}$ & $\mathbf{3 2}$ & $279.64 \pm 7.25$ & $16.65 \pm 0.03$ \\
\hline
\end{tabular}




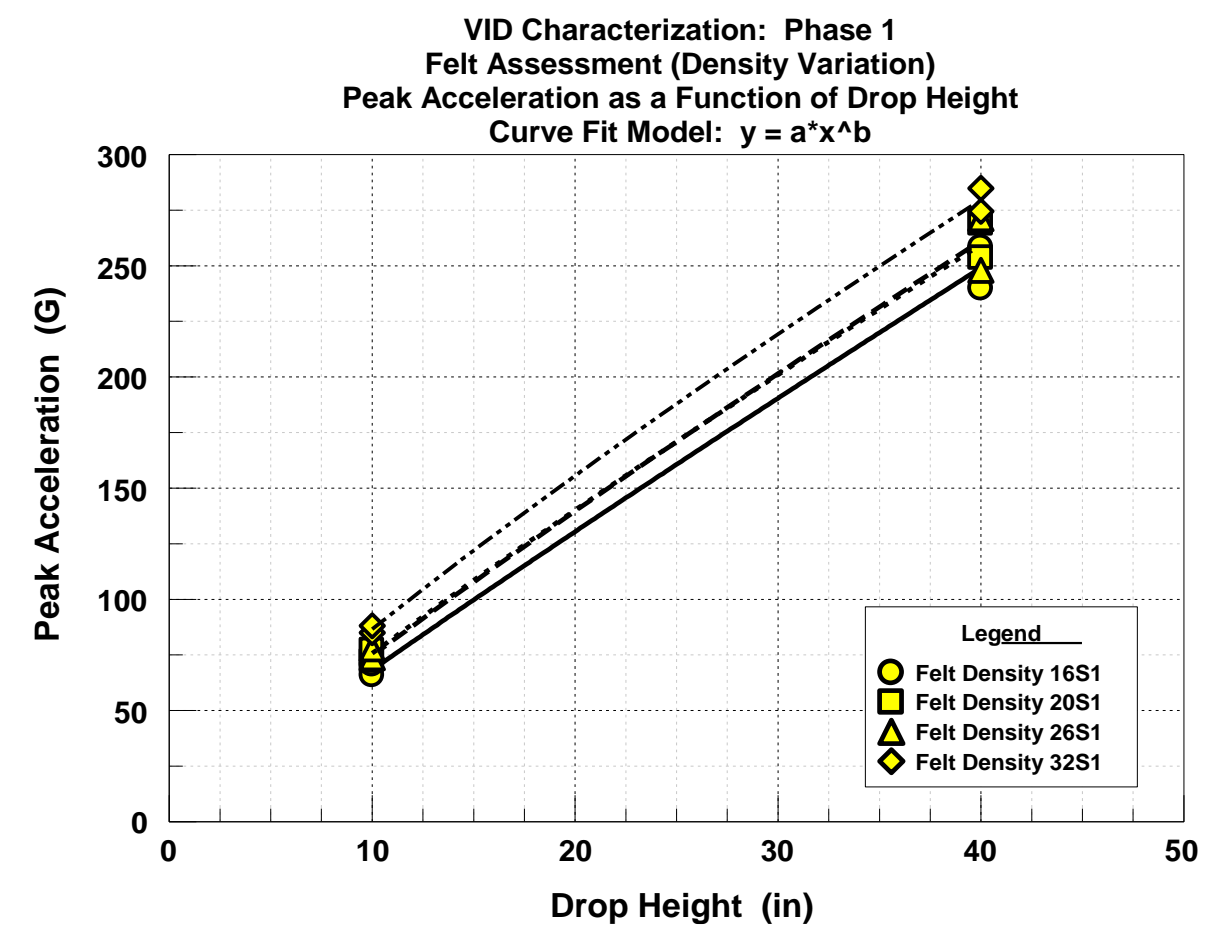

Figure 15. Peak Acceleration as a Function of Drop Height - Felt Density Variation

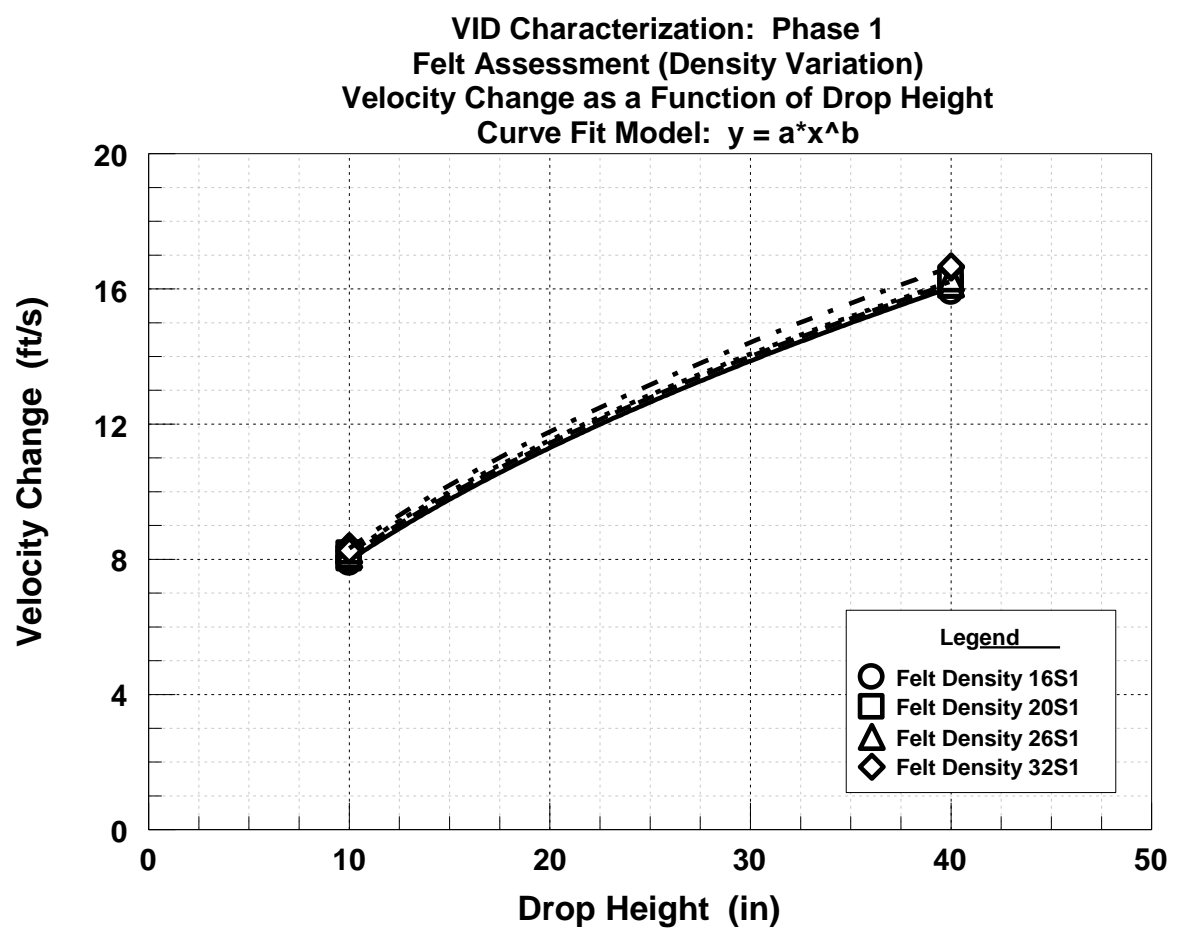

Figure 16. Velocity Change as a Function of Drop Height - Felt Density Variation

The data used to calculate the statistical means and standard deviations, for both the acceleration and calculated velocity change data sets, was composed of data from successful VID tests 1080 
through 1096. The accelerometer packages that were used for this test series were consistent through-out the testing. The narrow standard deviation values shown in Table 5 highlight the repeatability of the VID test facility.

A Power Series equation was assumed to be the best fit based on the excellent correlation with the red IMPAC programmer, and the plots generated from test data showed again that a Power Series equation $\left(y=a^{*} x^{b}\right)$ provided an excellent fit regression line for the different felt density samples. The peak impact acceleration as a function of drop height for all the felt density configurations was fit with a Power Series function forced to go through the origin. The velocity change as a function of drop height for all the felt density configurations was also fit with a Power Series function forced to go through the origin. The summary of the $a$ and $b$ coefficients for the function are shown in Table 6 as well as the Coefficient of Determination (COD) or $\mathrm{r}^{2}$ value for each regression. The excellent COD values for all the regression lines (minimum COD of 0.992) highlights the repeatability of the VID test facility and test set-up, and also provides a tool for estimation and prediction of required test parameters. 
Table 6. Felt Programmer Assessment (Density Variation): Curve Fit Model

(Curve Fit Model: $y=a^{*} x^{b}$ )

\begin{tabular}{|c|c|c|c|c|c|}
\hline $\begin{array}{c}\text { Dependent } \\
\text { Variable: } \\
\mathbf{y}\end{array}$ & $\begin{array}{c}\text { Independent } \\
\text { Variable: } \\
\mathbf{x}\end{array}$ & $\begin{array}{c}\text { Felt } \\
\text { Density } \\
\left.\mathbf{I l b}_{\mathbf{y d}} \mathbf{2}\right)\end{array}$ & $\begin{array}{c}\text { Model } \\
\text { Parameter: } \\
\mathbf{a}\end{array}$ & $\begin{array}{c}\text { Model } \\
\text { Parameter: } \\
\mathbf{b}\end{array}$ & $\begin{array}{c}\text { Coefficient of } \\
\text { Determination } \\
\mathbf{r}^{\mathbf{2}}\end{array}$ \\
\hline \hline $\begin{array}{c}\text { Peak } \\
\text { Acceleration }\end{array}$ & Drop Height & 16 & 7.97 & 0.933 & 0.994 \\
\hline $\begin{array}{c}\text { Peak } \\
\text { Acceleration }\end{array}$ & Drop Height & 20 & 9.34 & 0.903 & 0.996 \\
\hline $\begin{array}{c}\text { Peak } \\
\text { Acceleration }\end{array}$ & Drop Height & 25 & 9.78 & 0.889 & 0.992 \\
\hline $\begin{array}{c}\text { Peak } \\
\text { Acceleration }\end{array}$ & Drop Height & 32 & 12.34 & 0.846 & 0.998 \\
\hline \hline $\begin{array}{c}\text { Velocity } \\
\text { Change }\end{array}$ & Drop Height & 16 & 2.49 & 0.505 & 0.999 \\
\hline $\begin{array}{c}\text { Velocity } \\
\text { Change }\end{array}$ & Drop Height & 20 & 2.57 & 0.499 & 0.999 \\
\hline $\begin{array}{c}\text { Velocity } \\
\text { Change }\end{array}$ & Drop Height & 25 & 2.63 & 0.493 & 0.999 \\
\hline $\begin{array}{l}\text { Velocity } \\
\text { Change }\end{array}$ & Drop Height & 32 & 2.63 & 0.500 & 0.999 \\
\hline
\end{tabular}

The time history data from two different felts at each drop height were used to plot the generated impact acceleration profiles as a function of time (Figure 17). Two waveforms were plotted for Felt $16 \mathrm{~S} 1$ at both the 10 and 40 inch drops showing the variation in pulse width as the drop height increases. An additional waveform was plotted for Felt 32S1 at the 40 inch drop height which allows for an assessment of pulse width variation as a function of the felt density (Felt $16 \mathrm{~S} 1$ versus Felt $32 \mathrm{~S} 1$ at 40 inch drop). The acceleration pulse width can be used as an estimator of the time-to-peak velocity which is the area under the acceleration curve as previously noted. Figure 17 shows the pulse width decreases from approximately $7.5 \mathrm{~ms}$ to 5.5 $\mathrm{ms}$ as the drop height increased from 10 inches to 40 inches. Figure 17 also compares the acceleration pulse width for the 16S1 and 32S1 felt samples and indicates that the higher density felt decreases the pulse width from around $5.5 \mathrm{~ms}$ to $4.5 \mathrm{~ms}$. 


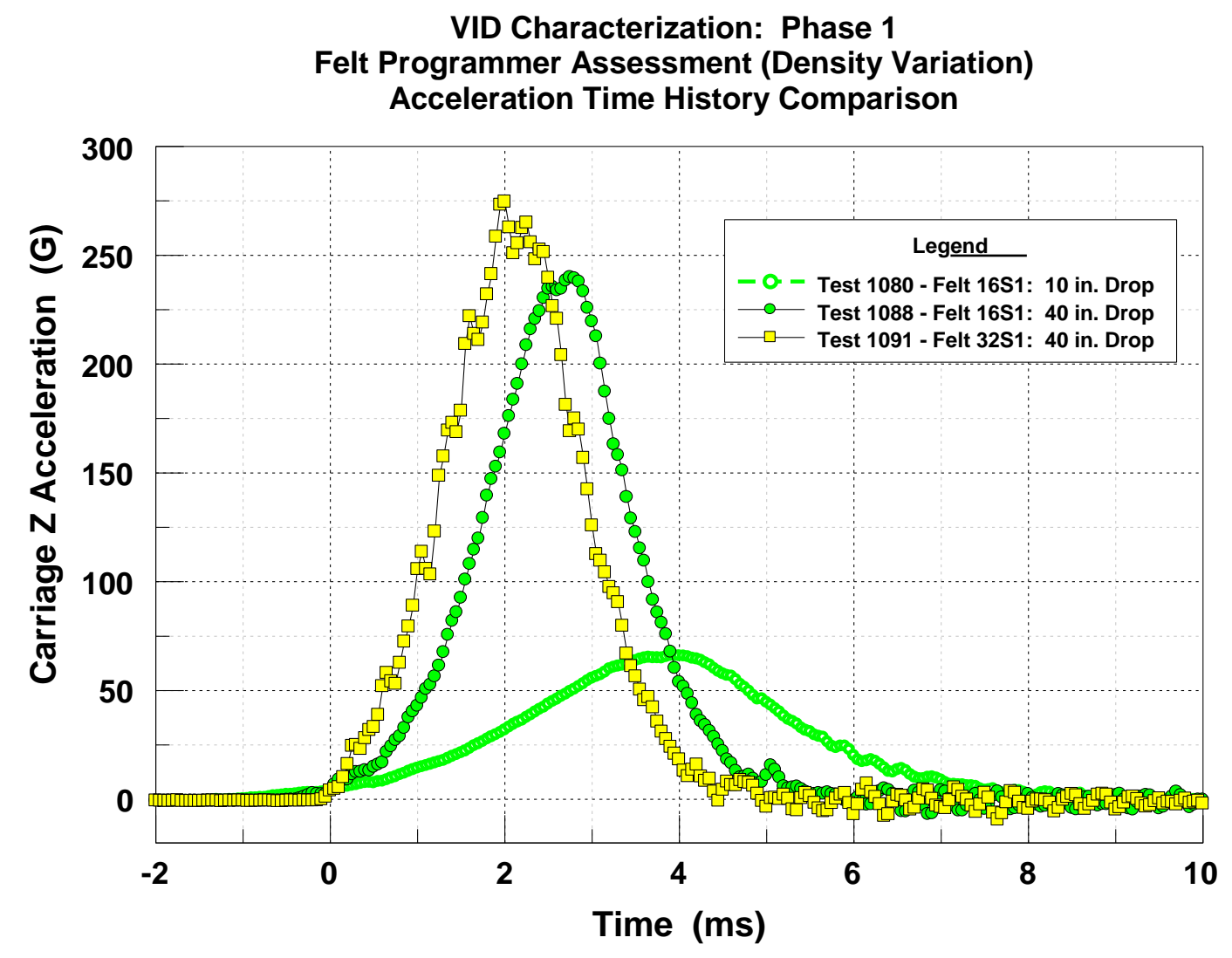

Figure 17. Acceleration Profiles at Two Drop Heights for Two Felt Density Samples

The regression lines identified in Table 6 for the acceleration and velocity response as a function of drop height were plotted for the $32 \mathrm{~S} 1$ felt only to provide prediction curves. This was done to determine the values for peak acceleration and maximum velocity change at the current maximum drop height of the VID facility which is approximately 80 inches. The prediction curves are shown in Figures 18 and 19, and show a peak acceleration of approximately $500 \mathrm{G}$, and a maximum velocity change of approximately $23 \mathrm{ft} / \mathrm{s}$, at a drop height of 80 inches. 


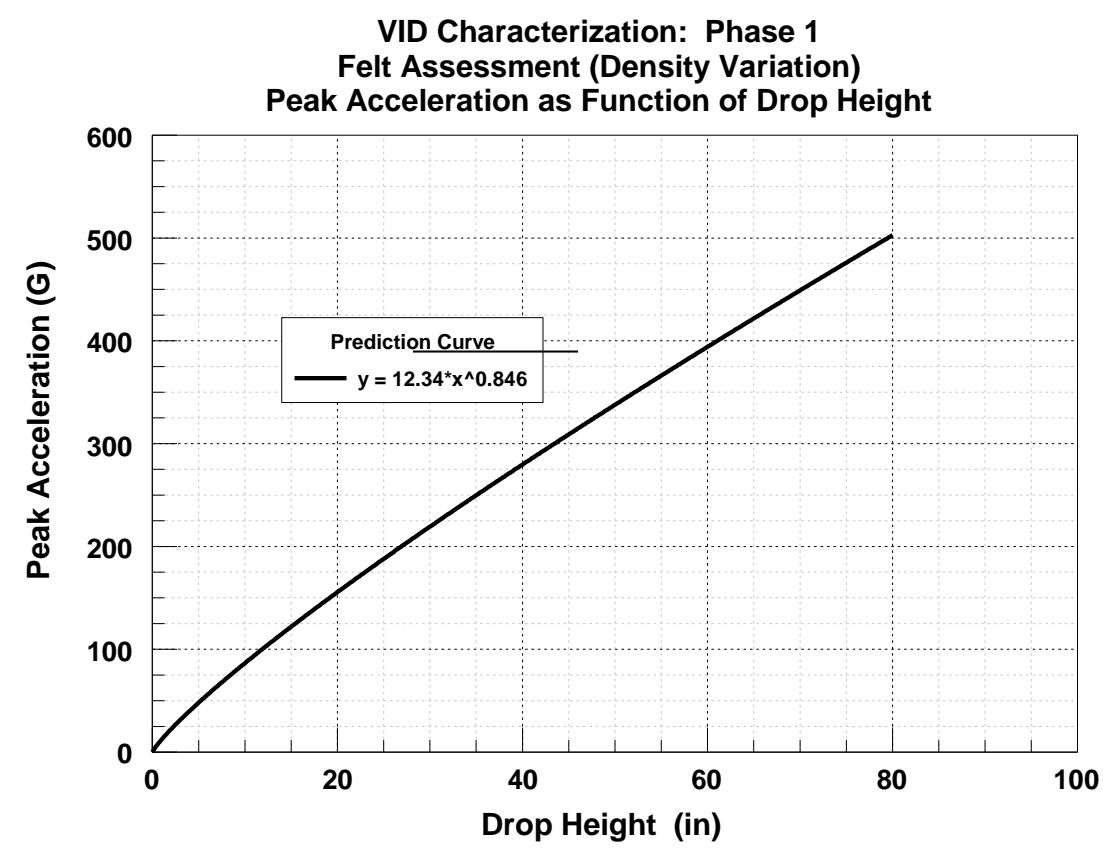

Figure 18. Prediction Curve for Peak Acceleration - Felt Density 32S1

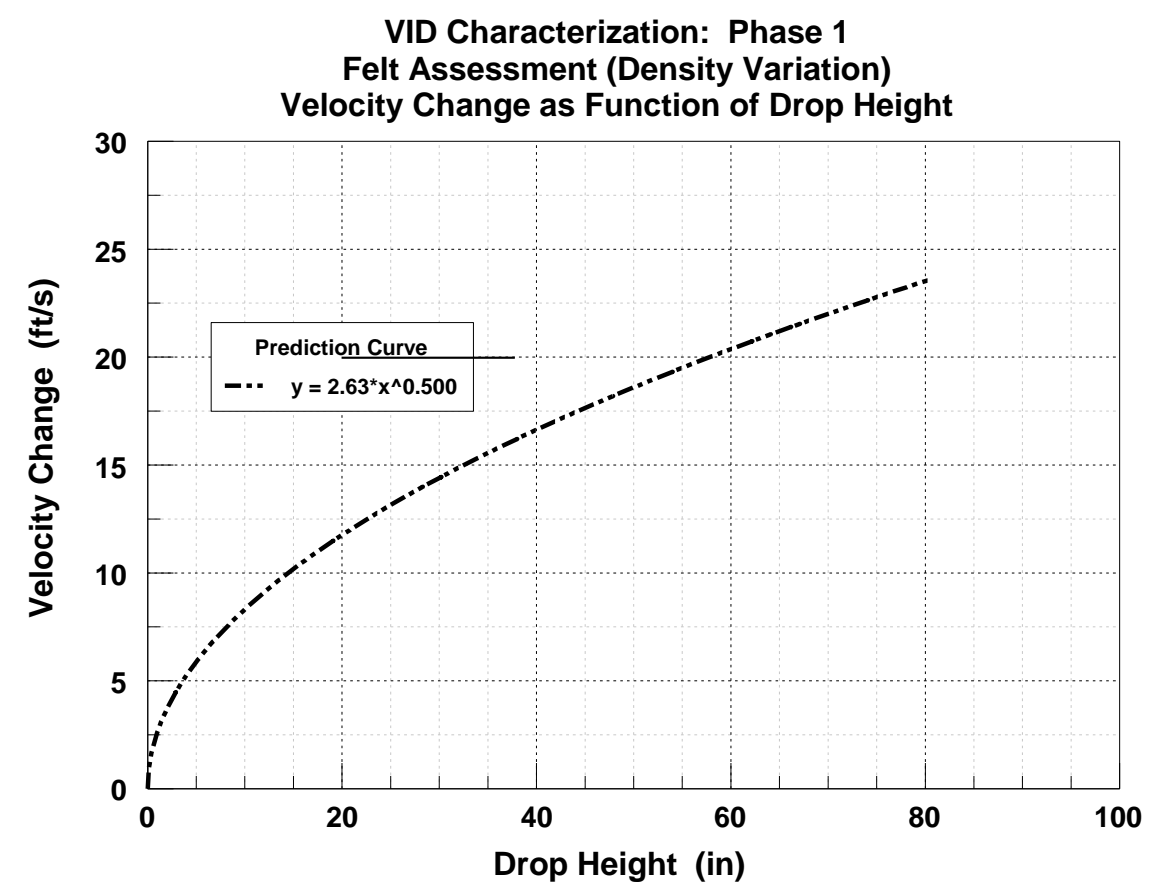

Figure 19. Prediction Curve for Velocity Change - Felt Density 32S1 
One aspect of the test data that Table 6 highlights is the minimal variation in response due to the variation of felt density. The values for regression parameters $a$ and $b$ are very close for both the peak acceleration and velocity change Power Series equations. This can be shown by calculation of the percent difference of the response due to the varying felt densities at each drop height. This allows a further understanding of the effects of varying felt density on both peak acceleration and integrated velocity change.

In order to calculate percent difference between data points collected at the two different drop height configurations, the percent difference was always referenced to a baseline value, and for this study, our baseline value or valueb was equal to that of Felt 16S1. The following equation was used to calculate the percent difference or Pd generated by varying the density:

$$
\mathrm{Pd}=\frac{\text { value }- \text { value }}{\text { valueb }} \times 100
$$

where value is the comparative data point from either the peak acceleration or velocity change data sets based on the felt density, and value is the baseline reference value which is either the peak acceleration or velocity change data value when the felt density was 16S1. An increasing $\mathrm{Pd}$ indicates that the acceleration or velocity increased with the increasing felt density. The percent difference data relative to Felt 16S1 is shown in Tables 7 and 8 for the peak acceleration and the velocity change data sets.

Table 7. Percent Difference in Peak Acceleration Relative to Felt 16S1

\begin{tabular}{|c|c|c|}
\hline \multirow{2}{*}{ Felt Density } & \multicolumn{2}{|c|}{ Drop Height } \\
\cline { 2 - 3 } & $\mathbf{1 0}$ in. & $\mathbf{4 0}$ in. \\
\hline \hline Felt 20S1 & $9.34 \%$ & $4.87 \%$ \\
\hline Felt 26S1 & $10.81 \%$ & $4.19 \%$ \\
\hline Felt 32S1 & $26.68 \%$ & $12.26 \%$ \\
\hline
\end{tabular}


Table 8. Percent Difference in Velocity Change Relative to Felt 16S1

\begin{tabular}{|c|c|c|}
\hline \multirow{2}{*}{ Felt Density } & \multicolumn{2}{|c|}{ Drop Height } \\
\cline { 2 - 3 } & $\mathbf{1 0}$ in. & $\mathbf{4 0}$ in. \\
\hline \hline Felt 20S1 & $1.76 \%$ & $0.80 \%$ \\
\hline Felt 26S1 & $2.89 \%$ & $1.12 \%$ \\
\hline Felt 32S1 & $5.90 \%$ & $3.80 \%$ \\
\hline
\end{tabular}

The percent difference values for the acceleration data indicate that the felt does not show much variation until the highest density felt (32S1) is used, and it appears that this variation decreases slightly as the drop height increases. The percent differences for the velocity change data demonstrate the same trend as the acceleration data but to a much smaller degree: generally, the felt density had very little effect on the velocity change at a given drop height. Overall, the felt density did show an increase in the peak acceleration change as a function of drop height, but the relative velocity change across the felt densities tested was very minimal until the highest density felt was used.

\subsection{Felt Programmer (Thickness Variation): Test-by-Test Summary}

A review of the specific test configuration for each of the tests conducted on the VID with different felt programmer configurations, that varied by felt thickness, is shown with a test-bytest summary documenting the test conditions and a brief summary of the key data. This is shown in Appendix F.

\subsection{Felt Programmer (Thickness Variation): Test Data Review}

The data collected from testing the different felt samples that varied in thickness is presented in Table 9, and corresponds with the test parameters proposed in Table 3 in the methods section. The felt density was constant for all tests by using 20S1 samples. Table 9 used all of the data at given drop heights for the statistical calculations. Both the resulting peak acceleration and integrated velocity change were able to be plotted as a function of progressively increasing drop heights, shown in Figures 20 and 21. Examples of the felt programmer data plots generated after each test, via the post-test "quick-looks", is shown in Appendix G. 
Table 9. Felt Programmer Assessment (Thickness Variation): Data Summary Showing Means and Standard Deviations

\begin{tabular}{|c|c|c|c|c|}
\hline Test Cell & $\begin{array}{c}\text { Drop } \\
\text { Height } \\
\text { (in) }\end{array}$ & $\begin{array}{c}\text { Felt } \\
\text { Thickness } \\
\text { (in) }\end{array}$ & $\begin{array}{c}\text { Mean Peak } \\
\text { Acceleration } \\
\text { (G) }\end{array}$ & $\begin{array}{c}\text { Mean } \\
\text { Velocity } \\
\text { (ft/s) }\end{array}$ \\
\hline \hline $\mathbf{Q}$ & 10 & 0.25 & $95.11 \pm 4.16$ & $8.22 \pm 0.10$ \\
\hline $\mathbf{R}$ & 10 & 0.50 & $81.16 \pm 0.85$ & $8.34 \pm 0.03$ \\
\hline $\mathbf{S}$ & 10 & 1.00 & $57.35 \pm 2.18$ & $8.49 \pm 0.11$ \\
\hline $\mathbf{T}$ & 10 & 2.00 & $41.66 \pm 0.37$ & $8.56 \pm 0.01$ \\
\hline $\mathbf{U}$ & 40 & 0.25 & $333.25 \pm 3.18$ & $16.42 \pm 0.06$ \\
\hline $\mathbf{V}$ & 40 & 0.50 & $280.12 \pm 5.27$ & $16.41 \pm 0.18$ \\
\hline $\mathbf{W}$ & 40 & 1.00 & $189.32 \pm 0.69$ & $16.41 \pm 0.18$ \\
\hline $\mathbf{X}$ & 40 & 2.00 & $115.64 \pm 3.95$ & $16.46 \pm 0.16$ \\
\hline
\end{tabular}


VID Characterization: Phase 1

Felt Assessment (Thickness Variation)

Peak Acceleration as a Function of Drop Height Curve Fit Model: $y=a^{\star} x^{\wedge} b$

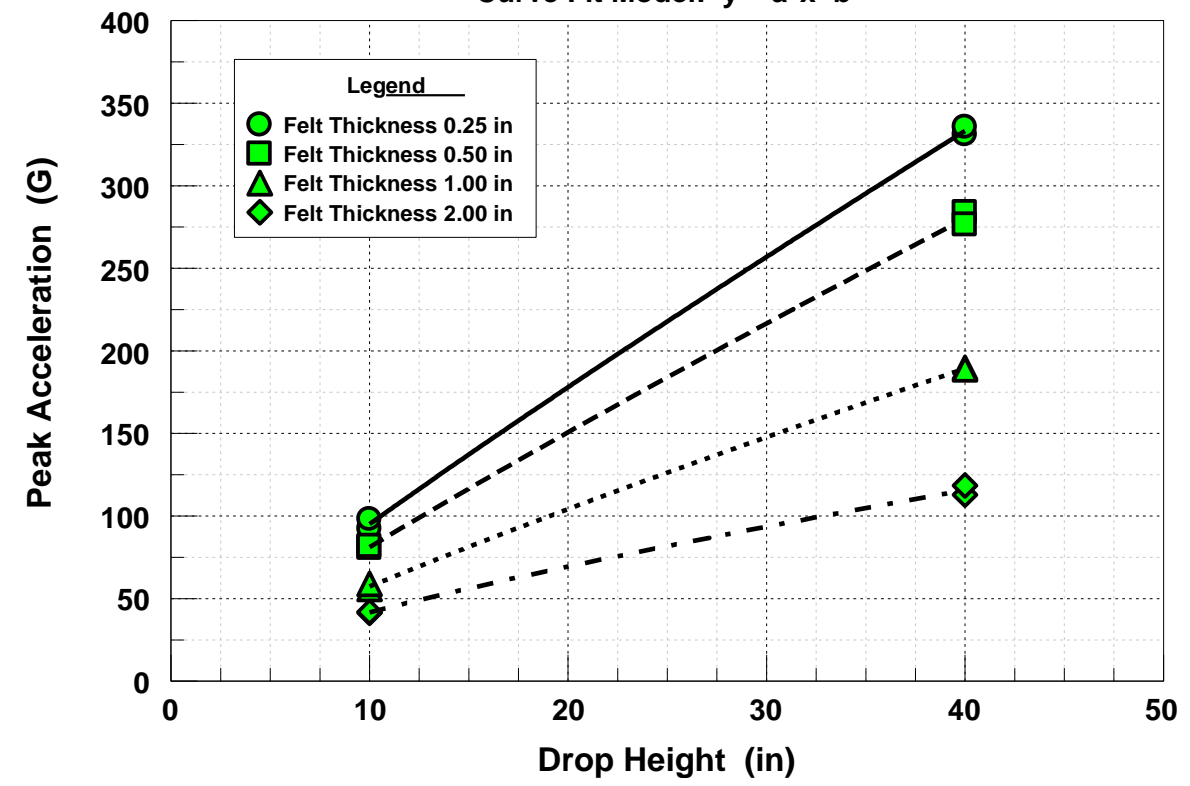

Figure 20. Peak Acceleration as a Function of Drop Height - Felt Thickness Variation

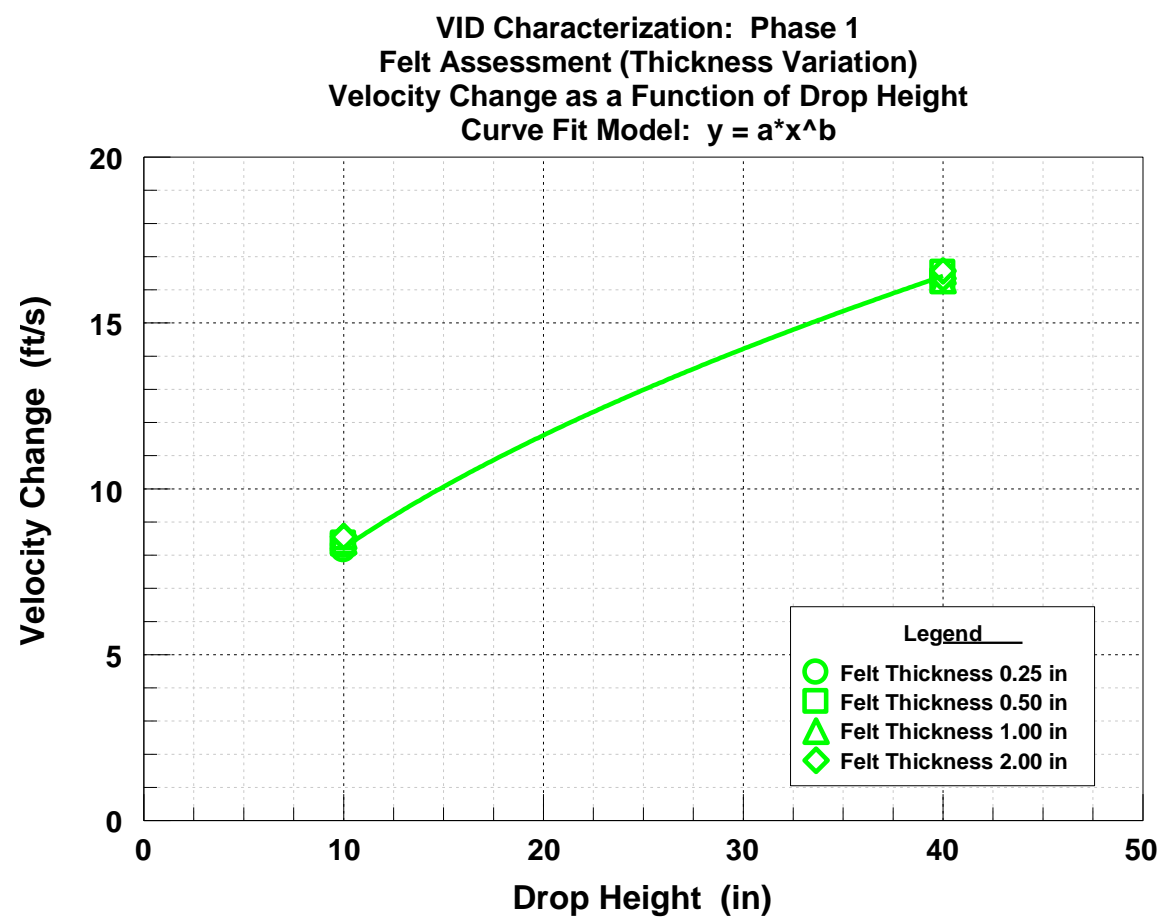

Figure 21. Velocity Change as a Function of Drop Height - Felt Thickness Variation 
The data used to calculate the statistical means and standard deviations, for both the acceleration and calculated velocity change data sets, was composed of data from successful VID tests 1097 through 1112. The accelerometer packages that were used for this test series were consistent throughout the testing. The narrow standard deviation values shown in Table 9 highlight the repeatability of the VID test facility.

A Power Series equation was assumed to be the best fit based on the excellent correlation with the red IMPAC programmer and the felt density tests, and the plots generated from test data showed again that a Power Series equation $\left(y=a^{*} x^{b}\right)$ provided an excellent fit regression line for the different felt thickness samples. The peak impact acceleration as a function of drop height for all the felt thickness configurations was fit with a Power Series function forced to go through the originch The velocity change as a function of drop height for all the felt density configurations was also fit with a Power Series function forced to go through the originch The summary of the $a$ and $b$ coefficients for the function are shown in Table 10 as well as the Coefficient of Determination (COD) or $\mathrm{r}^{2}$ value for each regression; however, only the coefficients for 0.25 inch thick felt are shown for the velocity change as the thickness did not alter the curve fit model. The excellent COD values for all the regression lines (minimum COD of 0.997 ) highlights the repeatability of the VID test facility and test set-up, and also provides a tool for estimation and prediction of required test parameters.

Table 10. Felt Programmer Assessment (Thickness Variation): Curve Fit Model (Curve Fit Model: $y=a^{*} x^{b}$ )

\begin{tabular}{|c|c|c|c|c|c|}
\hline $\begin{array}{c}\text { Dependent } \\
\text { Variable: } \\
\mathbf{y}\end{array}$ & $\begin{array}{c}\text { Independent } \\
\text { Variable: } \\
\mathbf{x}\end{array}$ & $\begin{array}{c}\text { Felt } \\
\text { Thickness } \\
\text { (in) }\end{array}$ & $\begin{array}{c}\text { Model } \\
\text { Parameter: } \\
\mathbf{a}\end{array}$ & $\begin{array}{c}\text { Model } \\
\text { Parameter: } \\
\mathbf{b}\end{array}$ & $\begin{array}{c}\text { Coefficient of } \\
\text { Determination } \\
\mathbf{r}^{\mathbf{2}}\end{array}$ \\
\hline \hline $\begin{array}{c}\text { Peak } \\
\text { Acceleration }\end{array}$ & Drop Height & 0.25 & 11.85 & 0.90 & 0.999 \\
\hline $\begin{array}{c}\text { Acceleration } \\
\text { Peak }\end{array}$ & Drop Height & 0.50 & 10.37 & 0.89 & 0.999 \\
\hline $\begin{array}{c}\text { Peak } \\
\text { Acceleration }\end{array}$ & Drop Height & 2.00 & 7.64 & 0.74 & 0.999 \\
\hline \hline \hline $\begin{array}{c}\text { Velocity } \\
\text { Change }\end{array}$ & Drop Height & 0.25 & 2.61 & 0.50 & 0.997 \\
\hline
\end{tabular}


The time history data from two different felt thickness samples at each drop height were used to plot the generated impact acceleration profiles as a function of time (Figure 22). Two waveforms were plotted for Felt 20S1, 0.25 inch thick sample, at both the 10 and 40 inch drops showing the variation in pulse width as the drop height increases. An additional waveform was plotted for Felt 20S1, 2.00 inch thick sample, at the 40 inch drop height which allows for an assessment of pulse width variation as a function of the felt thickness (Felt 20S1, 0.25 inch thickness versus Felt 20S1, 2.00 inch thickness). The acceleration pulse width can be used as an estimator of the time-to-peak velocity which is the area under the acceleration curve as previously noted. Figure 22 shows the pulse width decreases from approximately $6.5 \mathrm{~ms}$ to 4 $\mathrm{ms}$ as the drop height increased from 10 inches to 40 inches. Figure 22 also compares the acceleration pulse width for the 0.25 inch thick and the 2.0 inch thick felt samples, and indicates that the higher thickness felt increases the pulse width from around $4 \mathrm{~ms}$ to around $11 \mathrm{~ms}$. This change in felt thickness also dropped the peak $\mathrm{G}$ level from $336 \mathrm{G}$ to $118 \mathrm{G}$.

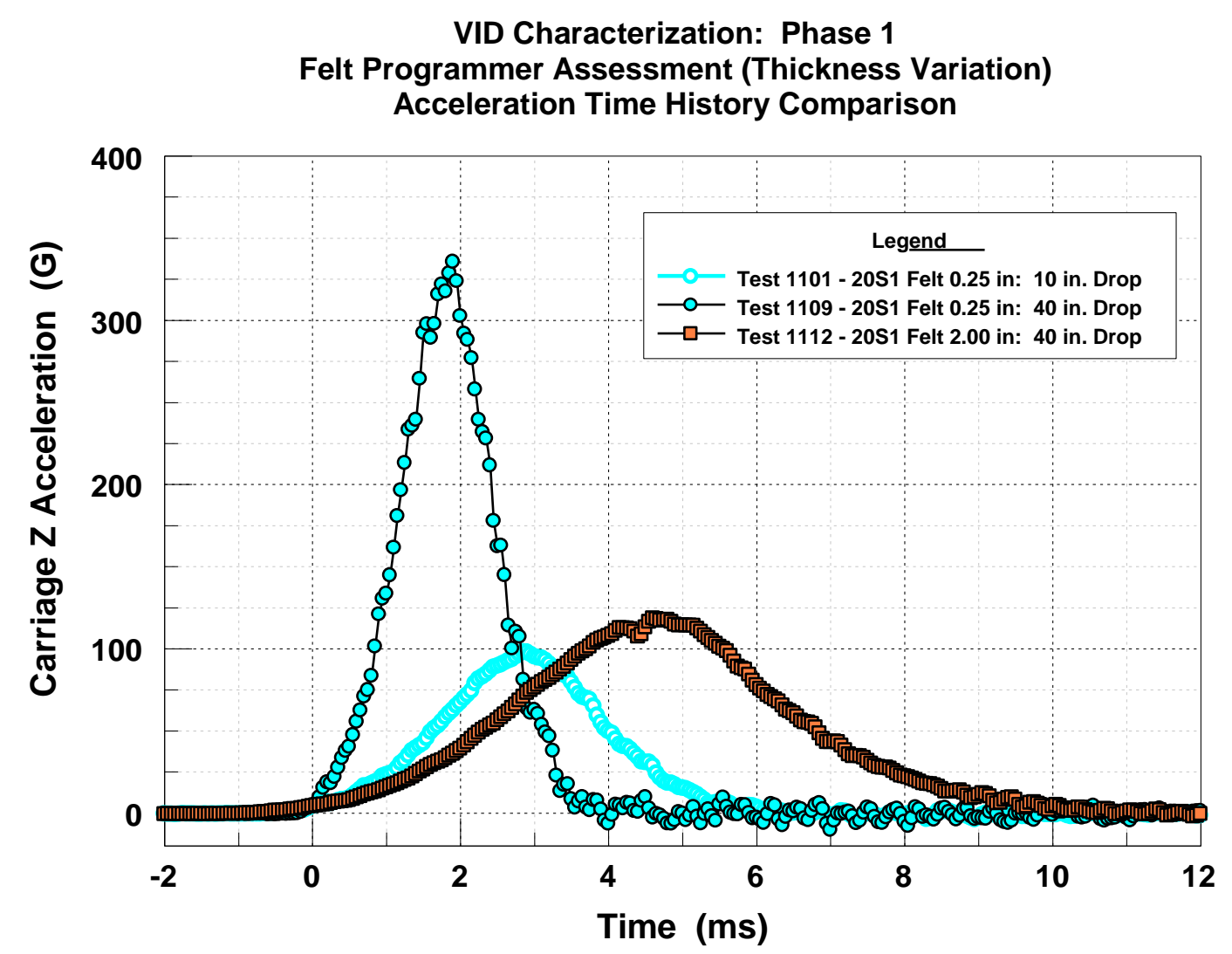

Figure 22. Acceleration Profiles at Two Drop Heights for Two Felt Thickness Samples 
The regression lines identified above for the acceleration and velocity response as a function of drop height were plotted for the 0.25 and 2.00 inch thick felt for acceleration response, and for the 0.25 inch thick felt for the velocity response, to provide prediction curves. This was done to determine the values for peak acceleration and maximum velocity change at the current maximum drop height of the VID facility which is approximately 80 inches. Only a single thickness was selected to provide a velocity change prediction curve due to the felt thickness parameter did not alter the curve fit model. The prediction curves are shown in Figures 23 and 24 , and show a peak acceleration of approximately $610 \mathrm{G}$ and $200 \mathrm{G}$ for the 0.25 and 2.00 inch thick felt samples respectively, and a maximum velocity change of approximately $23.5 \mathrm{ft} / \mathrm{s}$, at a drop height of 80 inches.

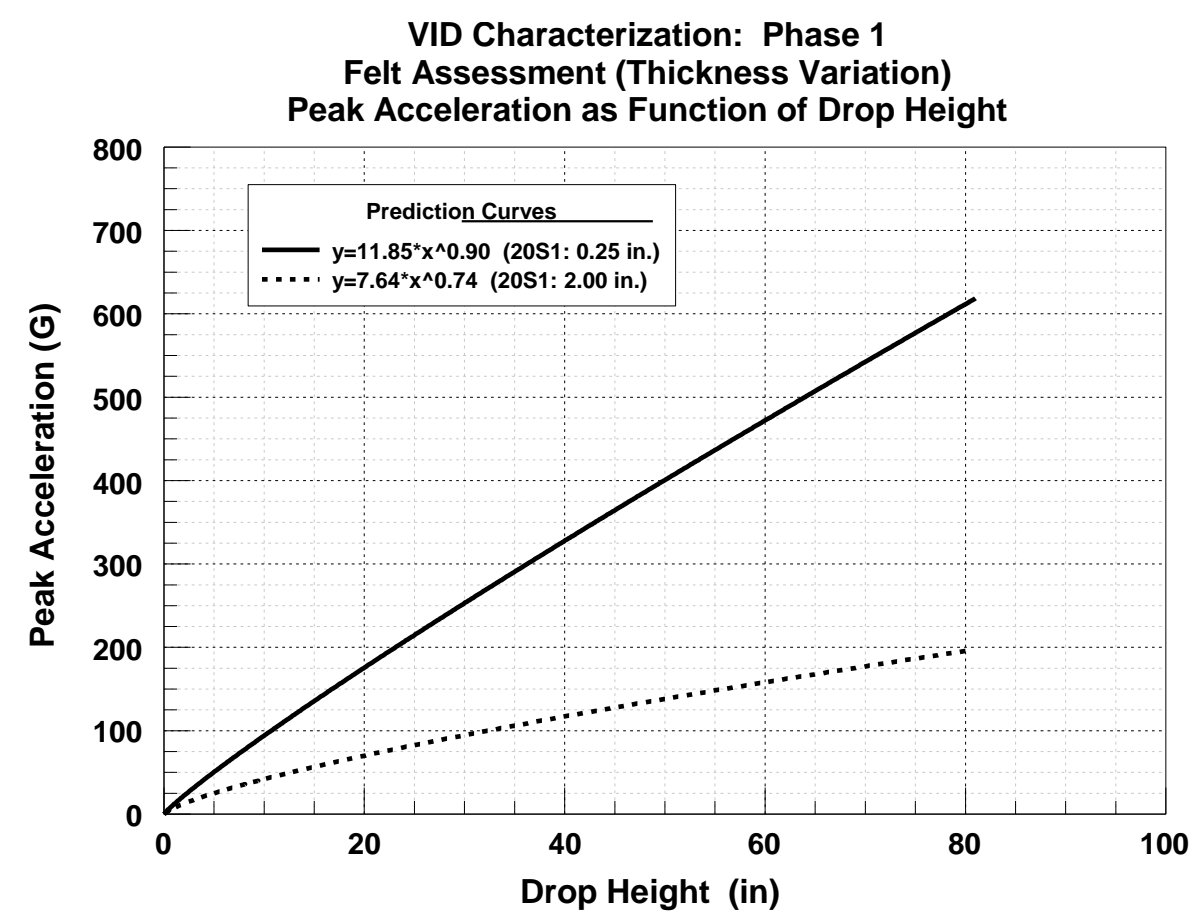

Figure 23. Prediction Curve for Peak Acceleration - Felt Thickness Variation 


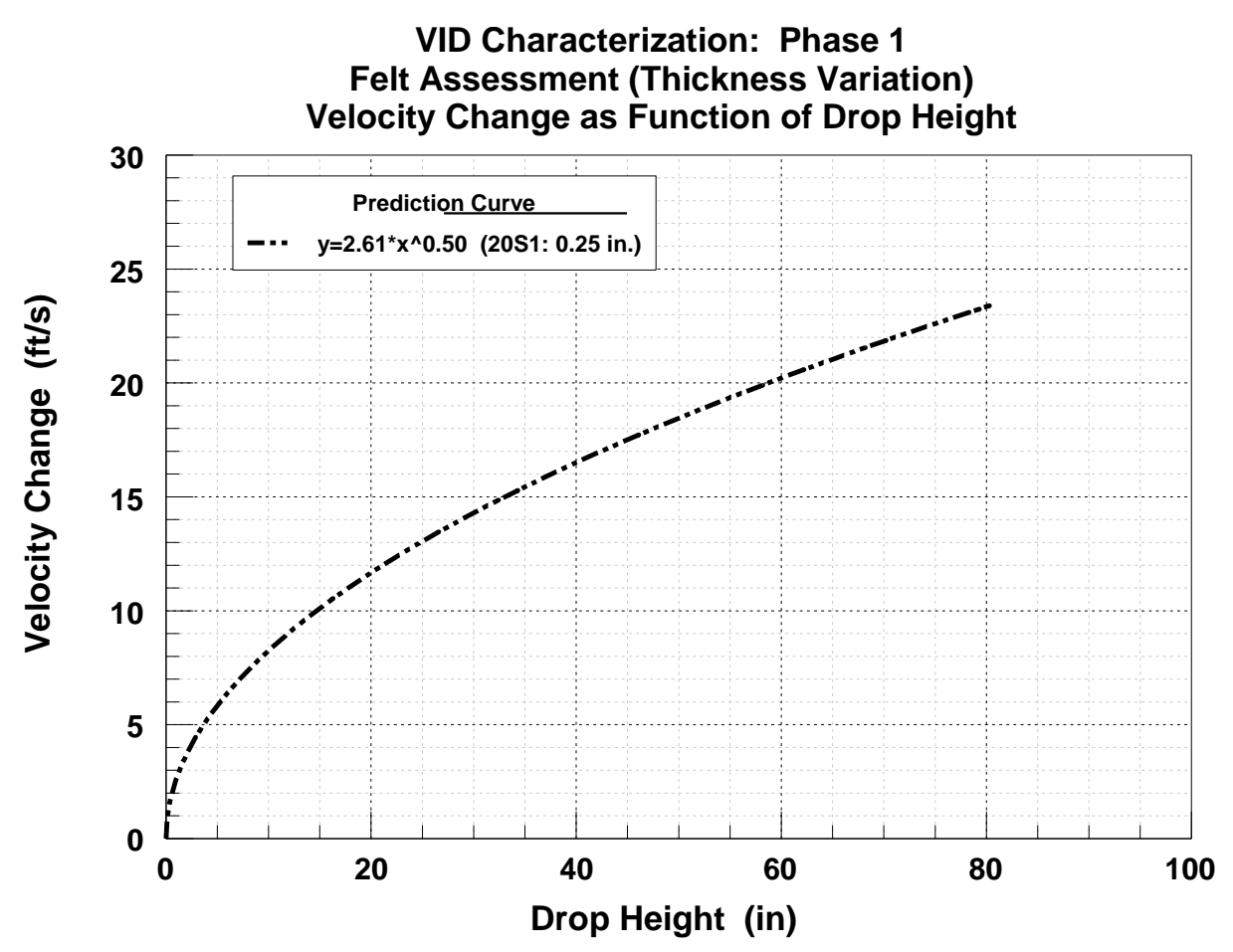

Figure 24. Prediction Curve for Velocity Change - Felt Thickness Variation

One aspect of the test data that Table 10 highlights is the variation in response due to the variation of felt thickness. The values for regression parameters $a$ and $b$ show a definite variation for the peak acceleration Power Series model fit, but are very close for the velocity change Power Series model fit. The degree of the variation in response can be illustrated by calculating the percent difference of the response due to the varying felt thicknesses at each drop height. This allows a further understanding of the effects of varying felt thickness on both peak acceleration and integrated velocity change.

In order to calculate percent difference between data points collected at the two different drop height configurations, the percent difference was always referenced to a baseline value, and for this study, our baseline value or valueb was equal to that of felt density 20S1 with a thickness of $0.25 \mathrm{inch}$. The following equation was used to calculate the percent difference or Pd generated by varying the thickness:

$$
\mathrm{Pd}=\frac{\text { value }- \text { value }}{\text { value }} \times 100
$$

where value is the comparative data point from either the peak acceleration or velocity change data sets based on the felt thickness, and valueb is the baseline reference value which is either the peak acceleration or velocity change data value when the felt sample was 0.25 inch thick $20 \mathrm{~S} 1$ felt. An increasing Pd indicates that the acceleration or velocity increased with the increasing felt thickness. The percent difference data relative to a felt thickness of $0.25 \mathrm{inch}$ is shown in Tables 11 and 12 for the peak acceleration and the velocity change data sets. 
Table 11. Percent Difference in Peak Acceleration Relative to Felt Thickness

\begin{tabular}{|c|c|c|}
\hline \multirow{2}{*}{ Felt Thickness } & \multicolumn{2}{|c|}{ Drop Height } \\
\cline { 2 - 3 } & $10 \mathrm{in.}$ & $\mathbf{4 0}$ in. \\
\hline \hline $0.50 \mathrm{in.}$ & $-14.7 \%$ & $-15.9 \%$ \\
\hline $1.00 \mathrm{in.}$ & $-39.7 \%$ & $-43.2 \%$ \\
\hline $2.00 \mathrm{in}$. & $-56.2 \%$ & $-65.3 \%$ \\
\hline
\end{tabular}

Table 12. Percent Difference in Velocity Change Relative to Felt Thickness

\begin{tabular}{|c|c|c|}
\hline \multirow{2}{*}{ Felt Thickness } & \multicolumn{2}{|c|}{ Drop Height } \\
\cline { 2 - 3 } & $\mathbf{1 0} \mathrm{in.}$ & $\mathbf{4 0} \mathrm{in.}$ \\
\hline \hline $0.50 \mathrm{in.}$ & $1.45 \%$ & $-0.06 \%$ \\
\hline $1.00 \mathrm{in}$. & $3.28 \%$ & $-0.06 \%$ \\
\hline $2.00 \mathrm{in}$. & $4.14 \%$ & $0.24 \%$ \\
\hline
\end{tabular}

The percent difference values for the acceleration data indicate that the felt thickness dramatically decreases the peak acceleration as the thickness increases from 0.25 to 2.0 inch thick. The percent differences for the velocity change data with varying thickness demonstrate the same trend as the velocity change data with varying density: the felt thickness has virtually no effect on the resultant velocity change at a given drop height. Overall, the felt thickness did show a significant effect in the peak acceleration as a function of drop height, but the relative velocity change across the felt densities tested was minimal. 


\subsection{SUMMARY AND CONCLUSIONS}

The ABP Team conducted a research effort to identify the performance capabilities of the Vertical Impact Device (VID) test located in Bldg 824, Wright Patterson AFB OH. The VID is a high-G impact test machine with seismic suspension, and is used to generate short duration, very high amplitude impact acceleration profiles to evaluate the effects on human and manikin subjects, and to define the effectiveness of operational and prototype protection concepts for the purpose of improving warfighter performance. The performance requirements for the VID were required to support the WIAMan program which had initial impact acceleration pulse requirements of over $300 \mathrm{G}$ with pulse TTP values in the 5 to $10 \mathrm{~ms}$ range. The test program approach used a parametric analysis with the objective to define and evaluate the performance effect of various impact attenuators on VID impact acceleration. Over 100 impact tests were completed during Phase I, and consisted of varying the energy attenuators, defined as the highdensity (red) urethane programmers and industrial felt of varying density and thickness, while progressively increasing the drop height of the VID's drop table. One red urethane programmer, 4 felt densities, and 4 felt thicknesses were evaluated, and were used as the basis to separate the data analysis into three sub-phases. The measured response was the acceleration recorded on the VID drop carriage, and the calculated velocity change and TTP velocity change.

The first phase of the VID performance assessment focused on the effect of the VID's red urethane programmers on the drop carriage impact acceleration as a function of drop height. Four programmers where used for each of the 24 impact tests used for the evaluation which consisted of three impacts at each of 8 different drop heights that ranged from 5 to 50 inches. Power Series equations were found to provide the best fit regression line for both increasing peak acceleration and velocity change as a function of drop height with each regression line having a COD of $\mathrm{r}^{2}=0.995$ or better. The acceleration pulse width was used as an estimator of the timeto-peak velocity, which is the area under the acceleration curve, and was found to decrease from approximately $5.5 \mathrm{~ms}$ to $3.0 \mathrm{~ms}$ as the drop height increased from 5 inches to 50 inches. Overall, the red programmers would provide a maximum impact acceleration of approximately $650 \mathrm{G}$, and a maximum velocity change of $23 \mathrm{ft} / \mathrm{s}$ at a drop height of 80 inches based on the Power Series regression equations.

The second phase of the VID performance assessment focused on the effect of variable felt density programmers on the drop carriage impact acceleration as a function of drop height. Four different felt densities at a constant thickness of 0.50 inches were used for the 16 impact tests conducted at two drop heights of 10 and 40 inches (two tests per density per drop height). Power Series equations through the origin were chosen for the regression fit based on the excellent correlation with the extensive red urethane programmer data, and were found to provide fit regression lines for both increasing peak acceleration and velocity change as a function of drop height with each regression line having a COD of $\mathrm{r}^{2}=0.992$ or better. The highest density felt (32S1) provided the largest impact acceleration of approximately $280 \mathrm{G}$ at the greatest drop height. The acceleration pulse width was used as an estimator of the time-to-peak velocity, which is the area under the acceleration curve, and was found to decrease from approximately $7.5 \mathrm{~ms}$ to $5.5 \mathrm{~ms}$ as the drop height increased from 10 inches to 40 inches using the least dense felt. The pulse width was also found to decrease from 5.5 to $4.5 \mathrm{~ms}$ as the felt density varied from the least dense felt to the highest density felt at the same drop height (40 inches). Overall, 
the felt density variation had a minimal effect on the peak acceleration or velocity change at the two drop heights. This was shown by calculating a percent difference in the response relative to a baseline which was the least dense felt. The peak acceleration for the highest density felt had a percent increase of $26 \%$ which dropped to $12 \%$ when the drop height increased from 10 to 40 inches. This can be explained by understanding that as the drop height increased, the acceleration pulse decreased in width, and as the felt density increased, the acceleration pulse also decreased in width; however, the drop height variation had a greater affect.

The third phase of the VID performance assessment focused on the effect of variable felt thickness programmers on the drop carriage impact acceleration as a function of drop height. Four different felt thicknesses at a constant density (20S1 samples) were used for the 16 impact tests conducted at two drop heights of 10 and 40 inches (two tests per thickness per drop height). Power Series equations through the origin were chosen for the regression fit based on the excellent correlation shown with the extensive red urethane programmer data, and were found to provide fit regression lines for both increasing peak acceleration and velocity change as a function of drop height with each regression line having a COD of $\mathrm{r}^{2}=0.997$ or better. The 0.25 inch thick felt provided the largest impact acceleration of approximately $333 \mathrm{G}$ at the greatest drop height. The acceleration pulse width was used as an estimator of the time-to-peak velocity, which is the area under the acceleration curve, and was found to decrease from approximately $6.5 \mathrm{~ms}$ to $4.0 \mathrm{~ms}$ as the drop height increased from 10 inches to 40 inches using the 0.25 inch thick felt. However, the pulse width was found to increase from $4 \mathrm{~ms}$ to $11 \mathrm{~ms}$ as the felt thickness increased from 0.25 to 2.0 inch thick at the same drop height ( 40 inches). Overall, the felt thickness variation had a very little effect on the velocity change at the two drop heights, but had a large effect on the peak acceleration and the acceleration pulse width at the two drop heights. This was shown by calculating a percent difference in the response relative to a baseline which was the least thick felt. The peak acceleration for the thinnest felt was $56 \%$ greater than the thickest felt at 10 inch drop height, and $65 \%$ greater than the thickest felt at a 40 inch drop height. As with the felt density assessment, this can be explained by understanding that as the drop height increased, the acceleration pulse increased in magnitude and decreased slightly in width, but as the felt density increased, the acceleration pulse had a significant decrease in magnitude, and had a significant increase in pulse width. It can be theorized that the increasing felt thickness affected the distribution of energy by stretching the acceleration pulse out (increased pulse width) without altering the magnitude of the energy as evidenced by the very minor variations in velocity change for the compared acceleration pulses. 


\section{BIBLIOGRAPHY/REFERENCES}

Knox, T., Pellettiere, J., Perry, C., Plaga, J., Bonfeld, J. (2008). New Sensors to Track Head Acceleration During Possible Injurious Events. SAE International: Journal of Passenger Cars Electronic Electrical Systems, Vol. 1(1): 652-663

Childers, M.A. (2002). Evaluation of the IMPAC66 Shock Test machine, Serial Number 118 (Technical Report ARL-TR-2840). Aberdeen Proving Ground: Weapons and Materials Research Directorate, Army Research Laboratory.

Veridian Contract Report (2002). Test Configuration and Data Acquisition System for Evaluation for Ejection Data Acquisition and Recorder Module (Veridian Engineering Division, CDRL A005 under Contract F41624-97-D-6004). Wright Patterson AFB: Human Effectiveness Directorate, Human Performance Wing, Air Force Research Laboratory.

Salerno, Capt. M.D., Brinkley, J.W., Orzech, Capt. M.A. (1985). Dynamic Response of the Human Head to +Gx Impact. SAFE Journal, Vol. 17 (4): 36-42. 


\section{GLOSSARY}

$\begin{array}{ll}\text { ABP } & \text { Aircrew Biodynamics and Protection } \\ \text { AFRL } & \text { Air Force Research Laboratory } \\ \text { COD } & \text { Coefficient of Determination } \\ \text { DAS } & \text { Data Acquisition System } \\ \text { DC } & \text { Direct Current } \\ \text { DoD } & \text { Department of Defense } \\ \text { DTS } & \text { Diversified Technical Systems } \\ \text { IED } & \text { Improvised Explosive Device } \\ \text { HPW } & \text { Human Performance Wing } \\ \text { NASA } & \text { National Aeronautics and Space Administration } \\ \text { USAF } & \text { United States Air Force } \\ \text { VID } & \text { Vertical Impact Device } \\ \text { WIAMan } & \text { Warrior Injury Assessment Manikin } \\ \text { WPAFB } & \text { Wright Patterson Air Force Base } \\ \text { WWI } & \text { World War I }\end{array}$




\section{APPENDIX A: ELECTRONIC DATA CHANNELS}




\begin{tabular}{|c|c|c|c|c|c|c|c|c|c|c|c|c|}
\hline \multicolumn{6}{|c|}{$\begin{array}{l}\text { PROGRAM: CHARACTERIZATION OF VERTICAL IMPACT DEVICE } \\
\text { ACCELERATION PULSES USING PARAMETRIC ASSMENT (PHASE I) }\end{array}$} & \multicolumn{7}{|c|}{$\begin{array}{l}\text { TEST DATES: } 4 \text { - } 5 \text { APR } 2013 \text {; } 8 \text { - } 9 \text { APR 2013; } 30 \text { APR 2013; } 2 \text { MAY 2013; } 7 \text { MAY 2013; } \\
13 \text { - } 15 \text { MAY } 2013\end{array}$} \\
\hline \multicolumn{6}{|c|}{ STUDY NUMBER: 201304} & \multicolumn{7}{|c|}{$\begin{array}{l}\text { TEST NUMBERS: } 1015 \text { - 1021; } 1022 \text { - 1027; } 1029 \text { - 1045; } 1046 \text { - 1051; } 1052 \text { - 1059; } 1060 \text { - } \\
\text { 1079; } 1080 \text { - } 1112\end{array}$} \\
\hline \multicolumn{6}{|c|}{ FACILITY: VID } & \multicolumn{7}{|c|}{ SAMPLE RATE: $20 \mathrm{Khz}$} \\
\hline \multicolumn{6}{|c|}{ DATA COLLECTION SYSTEM: TDAS G5 } & \multicolumn{7}{|c|}{ FILTER FREQUENCY: $2 \mathrm{Khz}$} \\
\hline & & & & & & \multicolumn{7}{|c|}{ TRANSDUCER RANGE (VOLTS): $+/-5 \mathrm{~V}$} \\
\hline \multirow{2}{*}{$\begin{array}{l}\text { DATA } \\
\text { CHANNEL }\end{array}$} & \multirow{2}{*}{$\begin{array}{l}\text { DATA } \\
\text { POINT }\end{array}$} & \multirow{2}{*}{$\begin{array}{l}\text { TRANSDUCER } \\
\text { MFG. \& MODEL }\end{array}$} & \multirow{2}{*}{$\begin{array}{l}\text { SERIAL } \\
\text { NUMBER }\end{array}$} & \multicolumn{2}{|l|}{ PRE-CAL } & \multicolumn{2}{|l|}{ POST-CAL } & \multirow[t]{2}{*}{$\% \mathrm{D}$} & \multirow{2}{*}{$\begin{array}{l}\text { DAS } \\
\text { SENSITIVITY }\end{array}$} & \multirow[t]{2}{*}{ BRIDGE } & \multirow{2}{*}{$\begin{array}{l}\text { FULL } \\
\text { SCALE }\end{array}$} & \multirow[t]{2}{*}{ NOTES } \\
\hline & & & & DATE & SENS & DATE & SENS & & & & & \\
\hline 1 & $\begin{array}{l}\text { CARRIAGE X } \\
\text { ACCCEL (G) }\end{array}$ & $\begin{array}{l}\text { ENTRAN } \\
7264 C-500\end{array}$ & P11264 & 12-Mar-13 & $\begin{array}{l}.7494 \mathrm{mv} / \mathrm{g} \\
\text { at } 10 \mathrm{~V} \mathrm{exc}\end{array}$ & 22-May-13 & $\begin{array}{l}.7449 \mathrm{mv} / \mathrm{g} \\
\text { at } 10 \mathrm{~V} \mathrm{exc}\end{array}$ & -0.6 & $\begin{array}{l}.07494 \\
\mathrm{mv} / \mathrm{v} / \mathrm{g}\end{array}$ & FULL & $200 \mathrm{G}$ & \\
\hline 2 & $\begin{array}{l}\text { CARRIAGE Y } \\
\text { ACCCEL (G) }\end{array}$ & $\begin{array}{l}\text { ENTRAN } \\
7264 C-500\end{array}$ & P11265 & 12-Mar-13 & $\begin{array}{l}.7036 \mathrm{mv} / \mathrm{g} \\
\text { at } 10 \mathrm{~V} \mathrm{exc}\end{array}$ & 22-May-13 & $\begin{array}{l}.6996 \mathrm{mv} / \mathrm{g} \\
\text { at } 10 \mathrm{~V} \mathrm{exc}\end{array}$ & -0.6 & $\begin{array}{l}.07036 \\
\mathrm{mv} / \mathrm{v} / \mathrm{g}\end{array}$ & FULL & $200 \mathrm{G}$ & \\
\hline 4 & $\begin{array}{l}\text { CARRIAGE X1 } \\
\text { ACCCEL (G) }\end{array}$ & $\begin{array}{l}\text { ENTRAN } \\
7264 C-500\end{array}$ & P11263 & 12-Mar-13 & $\begin{array}{l}.7127 \mathrm{mv} / \mathrm{g} \\
\text { at } 10 \mathrm{~V} \mathrm{exc}\end{array}$ & 22-May-13 & $\begin{array}{l}.7098 \mathrm{mv} / \mathrm{g} \\
\text { at } 10 \mathrm{~V} \mathrm{exc}\end{array}$ & -0.4 & $\begin{array}{l}.07127 \\
\mathrm{mv} / \mathrm{v} / \mathrm{g}\end{array}$ & FULL & $200 \mathrm{G}$ & \\
\hline 5 & $\begin{array}{l}\text { CARRIAGE Y1 } \\
\text { ACCCEL (G) }\end{array}$ & $\begin{array}{l}\text { ENTRAN } \\
7264 C-500\end{array}$ & P11262 & 13-Mar-13 & $\begin{array}{l}.6957 \mathrm{mv} / \mathrm{g} \\
\text { at } 10 \mathrm{~V} \mathrm{exc}\end{array}$ & 22-May-13 & $\begin{array}{l}.6926 \mathrm{mv} / \mathrm{g} \\
\text { at } 10 \mathrm{~V} \mathrm{exc}\end{array}$ & -0.4 & $\begin{array}{l}.06957 \\
\mathrm{mv} / \mathrm{v} / \mathrm{g}\end{array}$ & FULL & $200 \mathrm{G}$ & \\
\hline 6 & $\begin{array}{l}\text { CARRIAGE Z1 } \\
\text { ACCCEL (G) }\end{array}$ & $\begin{array}{l}\text { MEAS SPEC } \\
\text { EGCS-1000-S425 }\end{array}$ & N04732 & 05-Mar-13 & $\begin{array}{l}.1140 \mathrm{mv} / \mathrm{g} \\
\text { at } 10 \mathrm{~V} \mathrm{exc}\end{array}$ & 22-May-13 & $\begin{array}{l}.1148 \mathrm{mv} / \mathrm{g} \\
\text { at } 10 \mathrm{~V} \mathrm{exc}\end{array}$ & 0.7 & $\begin{array}{l}.01140 \\
\mathrm{mv} / \mathrm{v} / \mathrm{g}\end{array}$ & FULL & $1000 \mathrm{G}$ & \\
\hline 7 & $\begin{array}{l}\text { CARRIAGE X2 } \\
\text { ACCCEL (G) }\end{array}$ & $\begin{array}{l}\text { ENTRAN } \\
\text { 7264C-500 }\end{array}$ & P11260 & 24-Apr-13 & $\begin{array}{l}.6815 \mathrm{mv} / \mathrm{g} \\
\text { at } 10 \mathrm{~V} \mathrm{exc}\end{array}$ & 22-May-13 & $\begin{array}{l}.6781 \mathrm{mv} / \mathrm{g} \\
\text { at } 10 \mathrm{~V} \mathrm{exc}\end{array}$ & 0.5 & $\begin{array}{l}.06815 \\
\mathrm{mv} / \mathrm{v} / \mathrm{g}\end{array}$ & FULL & $200 \mathrm{G}$ & \\
\hline 8 & $\begin{array}{l}\text { CARRIAGE Y2 } \\
\text { ACCCEL (G) }\end{array}$ & $\begin{array}{l}\text { ENTRAN } \\
7264 C-500\end{array}$ & P11261 & 12-Mar-13 & $\begin{array}{l}.6991 \mathrm{mv} / \mathrm{g} \\
\text { at } 10 \mathrm{~V} \mathrm{exc}\end{array}$ & 22-May-13 & $\begin{array}{l}.6971 \mathrm{mv} / \mathrm{g} \\
\text { at } 10 \mathrm{~V} \mathrm{exc}\end{array}$ & -0.3 & $\begin{array}{l}.06991 \\
\mathrm{mv} / \mathrm{v} / \mathrm{g}\end{array}$ & FULL & $200 \mathrm{G}$ & \\
\hline 9 & $\begin{array}{l}\text { CARRIAGE Z2 } \\
\text { ACCCEL (G) }\end{array}$ & $\begin{array}{l}\text { MEAS SPEC } \\
\text { EGCS-1000-S425 }\end{array}$ & N04742 & 05-Mar-13 & $\begin{array}{l}.1143 \mathrm{mv} / \mathrm{g} \\
\text { at } 10 \mathrm{~V} \mathrm{exc}\end{array}$ & 22-May-13 & $\begin{array}{l}.1148 \mathrm{mv} / \mathrm{g} \\
\text { at } 10 \mathrm{~V} \mathrm{exc}\end{array}$ & 0.5 & $\begin{array}{l}.01143 \\
\mathrm{mv} / \mathrm{v} / \mathrm{g}\end{array}$ & FULL & $1000 \mathrm{G}$ & \\
\hline 10 & $\begin{array}{l}\text { CARRIAGE Z } \\
\text { ACCCEL (G) }\end{array}$ & $\begin{array}{l}\text { MEAS SPEC } \\
\text { EGCS-1000-S425 }\end{array}$ & N04741 & 05-Mar-13 & $\begin{array}{l}.1135 \mathrm{mv} / \mathrm{g} \\
\text { at } 10 \mathrm{~V} \mathrm{exc}\end{array}$ & 22-May-13 & $\begin{array}{l}.1148 \mathrm{mv} / \mathrm{g} \\
\text { at } 10 \mathrm{~V} \text { exc }\end{array}$ & 1.2 & $\begin{array}{l}.01135 \\
\mathrm{mv} / \mathrm{v} / \mathrm{g}\end{array}$ & FULL & $1000 \mathrm{G}$ & \\
\hline & & & & & & & & & & & & \\
\hline
\end{tabular}




\section{APPENDIX B. VID CHARACTERIZATION WITH RED IMPAC PROGRAMMERS: TEST-BY-TEST SUMMARY}

- Test 1015: Cell A, Test 1; Red IMPAC Programmer; Drop Height $=5$ inch, Peak G level $=73.96$, Integrated Velocity Change $=6.18 \mathrm{ft} / \mathrm{s}$, Time-to-Peak Acceleration $=2.4 \mathrm{~ms}$, Time-to-Peak Velocity $=5.5 \mathrm{~ms}$.

Successful Test - All electronic data channels were present and continuous, data was successfully collected, desired test condition was achieved.

- Test 1016: Cell A, Test 2; Red IMPAC Programmer; Drop Height $=5$ inch, Peak G level $=73.66$, Integrated Velocity Change $=6.11 \mathrm{ft} / \mathrm{s}$, Time-to-Peak Acceleration $=2.3 \mathrm{~ms}$, Time-to-Peak Velocity $=5.5 \mathrm{~ms}$.

Successful Test - All electronic data channels were present and continuous, data was successfully collected, desired test condition was achieved.

- Test 1017: Cell A, Test 3; Red IMPAC Programmer; Drop Height $=5$ inch, Peak G level $=74.18$, Integrated Velocity Change $=6.18 \mathrm{ft} / \mathrm{s}$, Time-to-Peak Acceleration $=2.4 \mathrm{~ms}$, Time-to-Peak Velocity $=5.3 \mathrm{~ms}$.

Successful Test - All electronic data channels were present and continuous, data was successfully collected, desired test condition was achieved.

- Test 1018: Cell B, Test 1; Red IMPAC Programmer; Drop Height $=10$ inch, Peak G level $=130.3$, Integrated Velocity Change $=10.32 \mathrm{ft} / \mathrm{s}$, Time-to-Peak Acceleration $=1.8$ $\mathrm{ms}$, Time-to-Peak Velocity $=4.4 \mathrm{~ms}$.

Successful Test - All electronic data channels were present and continuous, data was successfully collected, desired test condition was achieved; $Z$ acceleration data center.

- Test 1019: Cell B, Test 2; Red IMPAC Programmer; Drop Height $=12$ inch, Peak G level $=150.8$, Integrated Velocity Change $=11.98 \mathrm{ft} / \mathrm{s}$, Time-to-Peak Acceleration $=1.8$ $\mathrm{ms}$, Time-to-Peak Velocity $=4.3 \mathrm{~ms}$.

No Test - Desired conditions and reading were not achieved due to incorrect drop height; peak acceleration reading too high.

- Test 1020: Cell B, Test 2; Red IMPAC Programmer; Drop Height $=10$ inch, Peak G level $=108.52$, Integrated Velocity Change $=7.79 \mathrm{ft} / \mathrm{s}$, Time-to-Peak Acceleration $=1.9$ $\mathrm{ms}$, Time-to-Peak Velocity $=4.5 \mathrm{~ms}$.

Successful Test - All electronic data channels were present and continuous, data was successfully collected, desired test condition was achieved. 
- $\quad$ Test 1021: Cell B, Test 3; Red IMPAC Programmer; Drop Height $=10$ inch, Peak G level $=118.21$, Integrated Velocity Change $=8.4 \mathrm{ft} / \mathrm{s}$, Time-to-Peak Acceleration $=2 \mathrm{~ms}$, Time-to-Peak Velocity $=4.4 \mathrm{~ms}$.

Successful Test - All electronic data channels were present and continuous, data was successfully collected, desired test condition was achieved.

- $\quad$ Test 1022: Cell C, Test 1; Red IMPAC Programmer; Drop Height $=15$ inch, Peak G level $=169.57$, Integrated Velocity Change $=10.46 \mathrm{ft} / \mathrm{s}$, Time-to-Peak Acceleration $=2.1$ $\mathrm{ms}$, Time-to-Peak Velocity $=4.8 \mathrm{~ms}$.

Successful Test - All electronic data channels were present and continuous, data was successfully collected, desired test condition was achieved. Z1 block moved to left rail; $\mathrm{Z2}$ block moved to right rail; acceleration $\mathrm{Z}$ replaced with $4500 \mathrm{G}$ sensor.

- Test 1023: Cell C, Test 2; Red IMPAC Programmer; Drop Height $=15$ inch, Peak G level $=164.72$, Integrated Velocity Change $=10.32 \mathrm{ft} / \mathrm{s}$, Time-to-Peak Acceleration $=2.1$ $\mathrm{ms}$, Time-to-Peak Velocity $=4.8 \mathrm{~ms}$.

Successful Test - All electronic data channels were present and continuous, data was successfully collected, desired test condition was achieved.

- $\quad$ Test 1024: Cell C, Test 3; Red IMPAC Programmer; Drop Height $=15$ inch, Peak G level $=165.82$, Integrated Velocity Change $=10.34 \mathrm{ft} / \mathrm{s}$, Time-to-Peak Acceleration $=2$ $\mathrm{ms}$, Time-to-Peak Velocity $=4.8 \mathrm{~ms}$.

Successful Test - All electronic data channels were present and continuous, data was successfully collected, desired test condition was achieved.

- Test 1025: Cell D, Test 1; Red IMPAC Programmer; Drop Height $=20$ inch, Peak G level $=226.46$, Integrated Velocity Change $=12.33 \mathrm{ft} / \mathrm{s}$, Time-to-Peak Acceleration $=2$ $\mathrm{ms}$, Time-to-Peak Velocity $=4.3 \mathrm{~ms}$.

Successful Test - All electronic data channels were present and continuous, data was successfully collected, desired test condition was achieved. Carriage block switched with carriage $\mathrm{Z}$ block (Z, Z2 accel).

- $\quad$ Test 1026: Cell D, Test 2; Red IMPAC Programmer; Drop Height $=20$ inch, Peak G level $=224.46$, Integrated Velocity Change $=12.34 \mathrm{ft} / \mathrm{s}$, Time-to-Peak Acceleration $=2$ $\mathrm{ms}$, Time-to-Peak Velocity $=4.3 \mathrm{~ms}$.

Successful Test - All electronic data channels were present and continuous, data was successfully collected, desired test condition was achieved.

- $\quad$ Test 1027: Cell D, Test 3; Red IMPAC Programmer; Drop Height $=20$ inch, Peak G level $=224.46$, Integrated Velocity Change $=12.53 \mathrm{ft} / \mathrm{s}$, Time-to-Peak Acceleration $=2$ $\mathrm{ms}$, Time-to-Peak Velocity $=4.1 \mathrm{~ms}$.

Successful Test - All electronic data channels were present and continuous, data was successfully collected, desired test condition was achieved. 
- Test 1028: Cell E, Test 1; Red IMPAC Programmer; Drop Height $=25$ inch, Peak G level $=249.36$, Integrated Velocity Change $=13.48 \mathrm{ft} / \mathrm{s}$, Time-to-Peak Acceleration $=2$ $\mathrm{ms}$, Time-to-Peak Velocity $=3.8 \mathrm{~ms}$.

Successful Test - All electronic data channels were present and continuous, data was successfully collected, desired test condition was achieved.

- Test 1029: Cell E, Test 2; Red IMPAC Programmer; Drop Height $=25$ inch, Peak G level $=262.48$, Integrated Velocity Change $=13.51 \mathrm{ft} / \mathrm{s}$, Time-to-Peak Acceleration $=2$ $\mathrm{ms}$, Time-to-Peak Velocity $=3.8 \mathrm{~ms}$.

Successful Test - All electronic data channels were present and continuous, data was successfully collected, desired test condition was achieved.

- Test 1030: Cell E, Test 3; Red IMPAC Programmer; Drop Height $=25$ inch, Peak G level $=262.03$, Integrated Velocity Change $=13.42 \mathrm{ft} / \mathrm{s}$, Time-to-Peak Acceleration $=2$ $\mathrm{ms}$, Time-to-Peak Velocity $=3.8 \mathrm{~ms}$.

Successful Test - All electronic data channels were present and continuous, data was successfully collected, desired test condition was achieved.

- Test 1031: Cell F, Test 1; Red IMPAC Programmer; Drop Height $=30$ inch, Peak G level $=300.27$, Integrated Velocity Change $=14.19 \mathrm{ft} / \mathrm{s}$, Time-to-Peak Acceleration $=1.7$ $\mathrm{ms}$, Time-to-Peak Velocity $=3.5 \mathrm{~ms}$.

Successful Test - All electronic data channels were present and continuous, data was successfully collected, desired test condition was achieved.

- Test 1032: Cell F, Test 2; Red IMPAC Programmer; Drop Height $=30$ inch, Peak G level $=306.83$, Integrated Velocity Change $=14.64 \mathrm{ft} / \mathrm{s}$, Time-to-Peak Acceleration $=2$ $\mathrm{ms}$, Time-to-Peak Velocity $=4 \mathrm{~ms}$.

Successful Test - All electronic data channels were present and continuous, data was successfully collected, desired test condition was achieved.

- Test 1033: Cell F, Test 3; Red IMPAC Programmer; Drop Height $=30$ inch, Peak G level $=311.81$, Integrated Velocity Change $=14.94 \mathrm{ft} / \mathrm{s}$, Time-to-Peak Acceleration $=1.7$ $\mathrm{ms}$, Time-to-Peak Velocity $=3.5 \mathrm{~ms}$.

Successful Test - All electronic data channels were present and continuous, data was successfully collected, desired test condition was achieved.

- Test 1034: Cell G, Test 1; Red IMPAC Programmer; Drop Height $=40$ inch, Peak G level $=359.55$, Integrated Velocity Change $=14.56 \mathrm{ft} / \mathrm{s}$, Time-to-Peak Acceleration $=1.4$ $\mathrm{ms}$, Time-to-Peak Velocity $=3.2 \mathrm{~ms}$.

Successful Test - All electronic data channels were present and continuous, data was successfully collected, desired test condition was achieved. 
- Test 1035: Cell G, Test 2; Red IMPAC Programmer; Drop Height $=40$ inch, Peak G level $=356.77$, Integrated Velocity Change $=14.16 \mathrm{ft} / \mathrm{s}$, Time-to-Peak Acceleration $=1.4$ $\mathrm{ms}$, Time-to-Peak Velocity $=2.8 \mathrm{~ms}$.

Successful Test - All electronic data channels were present and continuous, data was successfully collected, desired test condition was achieved.

- Test 1036: Cell G, Test 3; Red IMPAC Programmer; Drop Height $=40$ inch, Peak G level $=377.9$, Integrated Velocity Change $=17.01 \mathrm{ft} / \mathrm{s}$, Time-to-Peak Acceleration $=1.5$ $\mathrm{ms}$, Time-to-Peak Velocity $=3.4 \mathrm{~ms}$.

Successful Test - All electronic data channels were present and continuous, data was successfully collected, desired test condition was achieved.

- Test 1037: Cell H, Test 1; Red IMPAC Programmer; Drop Height $=50$ inch, Peak G level $=378.02$, Integrated Velocity Change $=12.49 \mathrm{ft} / \mathrm{s}$, Time-to-Peak Acceleration $=1.2$ $\mathrm{ms}$, Time-to-Peak Velocity $=3.1 \mathrm{~ms}$.

Successful Test - All electronic data channels were present and continuous, data was successfully collected, desired test condition was achieved.

- Test 1038: Cell H, Test 2; Red IMPAC Programmer; Drop Height $=50$ inch, Peak G level $=338.27$, Integrated Velocity Change $=16.21 \mathrm{ft} / \mathrm{s}$, Time-to-Peak Acceleration $=1.2$ $\mathrm{ms}$, Time-to-Peak Velocity $=1.5 \mathrm{~ms}$.

Successful Test - All electronic data channels were present and continuous, data was successfully collected, desired test condition was achieved.

- Test 1039: Cell H, Test 3; Red IMPAC Programmer; Drop Height $=50$ inch, Peak G level $=340.47$, Integrated Velocity Change $=15.39 \mathrm{ft} / \mathrm{s}$, Time-to-Peak Acceleration $=1.2$ $\mathrm{ms}$, Time-to-Peak Velocity $=3.2 \mathrm{~ms}$.

Successful Test - All electronic data channels were present and continuous, data was successfully collected, desired test condition was achieved.

- Test 1040: Cell H1, Test 1; Red IMPAC Programmer; Drop Height $=50$ inch, Peak G level $=310.95$, Integrated Velocity Change $=14.08 \mathrm{ft} / \mathrm{s}$, Time-to-Peak Acceleration $=1.8$ $\mathrm{ms}$, Time-to-Peak Velocity $=3.2 \mathrm{~ms}$.

Successful Test - All electronic data channels were present and continuous, data was successfully collected, desired test condition was achieved. Side acceleration pack (Z2) moved to center next to Z-acceleration pack.

- Test 1041: Cell H1, Test 2; Red IMPAC Programmer; Drop Height $=50$ inch, Peak G level $=339.74$, Integrated Velocity Change $=15.71 \mathrm{ft} / \mathrm{s}$, Time-to-Peak Acceleration $=1.6$ $\mathrm{ms}$, Time-to-Peak Velocity $=3.1 \mathrm{~ms}$. 
Successful Test - All electronic data channels were present and continuous, data was successfully collected, desired test condition was achieved. Side acceleration pack (Z2) still in center.

- $\quad$ Test 1042: Cell H2, Test 1; Red IMPAC Programmer; Drop Height $=50$ inch, Peak G level $=306.85$, Integrated Velocity Change $=14.57 \mathrm{ft} / \mathrm{s}$, Time-to-Peak Acceleration $=1.8$ $\mathrm{ms}$, Time-to-Peak Velocity $=3.1 \mathrm{~ms}$.

Successful Test - All electronic data channels were present and continuous, data was successfully collected, desired test condition was achieved. $250 \mathrm{lbs}$. of weight secured to top VID carriage.

- Test 1043: Cell H2, Test 2; Red IMPAC Programmer; Drop Height $=50$ inch, Peak G level $=398.73$, Integrated Velocity Change $=17.4 \mathrm{ft} / \mathrm{s}$, Time-to-Peak Acceleration $=1.7$ $\mathrm{ms}$, Time-to-Peak Velocity $=3 \mathrm{~ms}$.

Successful Test - All electronic data channels were present and continuous, data was successfully collected, desired test condition was achieved. $250 \mathrm{lbs}$. of weight secured to top VID carriage.

- $\quad$ Test 1044: Cell E2, Test 1; Red IMPAC Programmer; Drop Height $=25$ inch, Peak G level $=267.29$, Integrated Velocity Change $=13.98 \mathrm{ft} / \mathrm{s}$, Time-to-Peak Acceleration $=1.9$ $\mathrm{ms}$, Time-to-Peak Velocity $=4.8 \mathrm{~ms}$.

Successful Test - All electronic data channels were present and continuous, data was successfully collected, desired test condition was achieved. $250 \mathrm{lbs}$. of weight secured to top VID carriage.

- Test 1045: Cell E2, Test 2; Red IMPAC Programmer; Drop Height $=25$ inch, Peak G level $=272.6$, Integrated Velocity Change $=13.95 \mathrm{ft} / \mathrm{s}$, Time-to-Peak Acceleration $=2$ $\mathrm{ms}$, Time-to-Peak Velocity $=4.1 \mathrm{~ms}$.

Successful Test - All electronic data channels were present and continuous, data was successfully collected, desired test condition was achieved. $250 \mathrm{lbs}$. of weight secured to top VID carriage.

- $\quad$ Test 1046: Cell F1, Test 1; Red IMPAC Programmer; Drop Height $=30$ inch, Peak G level $=283.65$, Integrated Velocity Change $=13.89 \mathrm{ft} / \mathrm{s}$, Time-to-Peak Acceleration $=1.6$ $\mathrm{ms}$, Time-to-Peak Velocity $=3.8 \mathrm{~ms}$.

Successful Test - All electronic data channels were present and continuous, data was successfully collected, desired test condition was achieved; new damped Z-Axis accelerators on each tri-axial block.

- $\quad$ Test 1047: Cell F1, Test 2; Red IMPAC Programmer; Drop Height $=30$ inch, Peak G level $=300.48$, Integrated Velocity Change $=14.29 \mathrm{ft} / \mathrm{s}$, Time-to-Peak Acceleration $=1.5$ $\mathrm{ms}$, Time-to-Peak Velocity $=4 \mathrm{~ms}$. 
Successful Test - All electronic data channels were present and continuous, data was successfully collected, desired test condition was achieved; new damped Z-Axis accelerators on each tri-axial block.

- Test 1048: Cell F1, Test 3; Red IMPAC Programmer; Drop Height $=30$ inch, Peak G level $=301.49$, Integrated Velocity Change $=14.32 \mathrm{ft} / \mathrm{s}$, Time-to-Peak Acceleration $=1.6$ $\mathrm{ms}$, Time-to-Peak Velocity $=3.7 \mathrm{~ms}$.

Successful Test - All electronic data channels were present and continuous, data was successfully collected, desired test condition was achieved; new damped Z-Axis accelerators on each tri-axial block.

- $\quad \underline{\text { Test 1049: }}$ Cell H3, Test 1; Red IMPAC Programmer; Drop Height $=50$ inch, Peak G level $=429.41$, Integrated Velocity Change $=18.21 \mathrm{ft} / \mathrm{s}$, Time-to-Peak Acceleration $=1.6$ $\mathrm{ms}$, Time-to-Peak Velocity $=4.2 \mathrm{~ms}$.

Successful Test - All electronic data channels were present and continuous, data was successfully collected, desired test condition was achieved. Addition of "damped" accelerometers to Z-axis of each tri-axial configuration ( 3 total).

- Test 1050: Cell H3, Test 2; Red IMPAC Programmer; Drop Height $=50$ inch, Peak G level $=443.33$, Integrated Velocity Change $=18.49 \mathrm{ft} / \mathrm{s}$, Time-to-Peak Acceleration $=1.5$ $\mathrm{ms}$, Time-to-Peak Velocity $=4.4 \mathrm{~ms}$.

Successful Test - All electronic data channels were present and continuous, data was successfully collected, desired test condition was achieved. Addition of "damped" accelerometers to Z-axis of each tri-axial configuration ( 3 total).

- Test 1051: Cell H3, Test 3; Red IMPAC Programmer; Drop Height $=50$ inch, Peak G level $=453.07$, Integrated Velocity Change $=18.72 \mathrm{ft} / \mathrm{s}$, Time-to-Peak Acceleration $=1.5$ $\mathrm{ms}$, Time-to-Peak Velocity $=4.3 \mathrm{~ms}$.

Successful Test - All electronic data channels were present and continuous, data was successfully collected, desired test condition was achieved. Addition of "damped" accelerometers to Z-axis of each tri-axial configuration (3 total).

- Test 1052: Cell A1, Test 1; Red IMPAC Programmer; Drop Height $=5$ inch, Peak G level $=70.84$, Integrated Velocity Change $=5.97 \mathrm{ft} / \mathrm{s}$, Time-to-Peak Acceleration $=2.3$ $\mathrm{ms}$, Time-to-Peak Velocity $=5.8 \mathrm{~ms}$.

Successful Test - All electronic data channels were present and continuous, data was successfully collected, desired test condition was achieved.

- Test 1053: Cell A1, Test 2; Red IMPAC Programmer; Drop Height $=5$ inch, Peak G level $=76.29$, Integrated Velocity Change $=6.21 \mathrm{ft} / \mathrm{s}$, Time-to-Peak Acceleration $=2.5$ $\mathrm{ms}$, Time-to-Peak Velocity $=5.5 \mathrm{~ms}$. 
Successful Test - All electronic data channels were present and continuous, data was successfully collected, desired test condition was achieved.

- Test 1054: Cell A1, Test 3; Red IMPAC Programmer; Drop Height $=5$ inch, Peak G level $=77.9$, Integrated Velocity Change $=6.29 \mathrm{ft} / \mathrm{s}$, Time-to-Peak Acceleration $=2.5 \mathrm{~ms}$, Time-to-Peak Velocity $=5.5 \mathrm{~ms}$.

Successful Test - All electronic data channels were present and continuous, data was successfully collected, desired test condition was achieved.

- Test 1055: Cell B1, Test 1; Red IMPAC Programmer; Drop Height $=10$ inch, Peak G level $=119.63$, Integrated Velocity Change $=8.36 \mathrm{ft} / \mathrm{s}$, Time-to-Peak Acceleration $=2$ $\mathrm{ms}$, Time-to-Peak Velocity $=4.7 \mathrm{~ms}$.

Successful Test - All electronic data channels were present and continuous, data was successfully collected, desired test condition was achieved.

- Test 1056: Cell B1, Test 2; Red IMPAC Programmer; Drop Height $=10$ inch, Peak G level $=120.44$, Integrated Velocity Change $=8.42 \mathrm{ft} / \mathrm{s}$, Time-to-Peak Acceleration $=1.9$ $\mathrm{ms}$, Time-to-Peak Velocity $=4.7 \mathrm{~ms}$.

Successful Test - All electronic data channels were present and continuous, data was successfully collected, desired test condition was achieved.

- Test 1057: Cell B1, Test 3; Red IMPAC Programmer; Drop Height $=10$ inch, Peak G level $=120.14$, Integrated Velocity Change $=8.41 \mathrm{ft} / \mathrm{s}$, Time-to-Peak Acceleration $=2$ $\mathrm{ms}$, Time-to-Peak Velocity $=4.7 \mathrm{~ms}$.

Successful Test - All electronic data channels were present and continuous, data was successfully collected, desired test condition was achieved.

- Test 1058: Cell C1, Test 1; Red IMPAC Programmer; Drop Height $=15$ inch, Peak G level $=169.35$, Integrated Velocity Change $=10.17 \mathrm{ft} / \mathrm{s}$, Time-to-Peak Acceleration $=2$ $\mathrm{ms}$, Time-to-Peak Velocity $=4.4 \mathrm{~ms}$.

Successful Test - All electronic data channels were present and continuous, data was successfully collected, desired test condition was achieved.

- Test 1059: Cell C1, Test 2; Red IMPAC Programmer; Drop Height = 15 inch, Peak G level $=178.09$, Integrated Velocity Change $=10.49 \mathrm{ft} / \mathrm{s}$, Time-to-Peak Acceleration $=2$ $\mathrm{ms}$, Time-to-Peak Velocity $=4.5 \mathrm{~ms}$.

Successful Test - All electronic data channels were present and continuous, data was successfully collected, desired test condition was achieved.

- Test 1060: Cell C1, Test 3; Red IMPAC Programmer; Drop Height = 15 inch, Peak G level $=173.15$, Integrated Velocity Change $=10.36 \mathrm{ft} / \mathrm{s}$, Time-to-Peak Acceleration $=2$ $\mathrm{ms}$, Time-to-Peak Velocity $=4.5 \mathrm{~ms}$. 
Successful Test - All electronic data channels were present and continuous, data was successfully collected, desired test condition was achieved.

- $\quad$ Test 1061: Cell D1, Test 1; Red IMPAC Programmer; Drop Height $=20$ inch, Peak G level $=213.46$, Integrated Velocity Change $=11.62 \mathrm{ft} / \mathrm{s}$, Time-to-Peak Acceleration $=2.1$ $\mathrm{ms}$, Time-to-Peak Velocity $=4.3 \mathrm{~ms}$.

Successful Test - All electronic data channels were present and continuous, data was successfully collected, desired test condition was achieved.

- Test 1062: Cell D1, Test 2; Red IMPAC Programmer; Drop Height $=20$ inch, Peak G level $=215.5$, Integrated Velocity Change $=11.77 \mathrm{ft} / \mathrm{s}$, Time-to-Peak Acceleration $=1.7$ $\mathrm{ms}$, Time-to-Peak Velocity $=4.3 \mathrm{~ms}$.

Successful Test - All electronic data channels were present and continuous, data was successfully collected, desired test condition was achieved.

- $\quad$ Test 1063: Cell D1, Test 3; Red IMPAC Programmer; Drop Height = 20 inch, Peak G level $=220.68$, Integrated Velocity Change $=11.9 \mathrm{ft} / \mathrm{s}$, Time-to-Peak Acceleration $=2$ $\mathrm{ms}$, Time-to-Peak Velocity $=4.3 \mathrm{~ms}$.

Successful Test - All electronic data channels were present and continuous, data was successfully collected, desired test condition was achieved.

- $\quad$ Test 1064: Cell E1, Test 1; Red IMPAC Programmer; Drop Height $=25$ inch, Peak G level $=277.05$, Integrated Velocity Change $=13.29 \mathrm{ft} / \mathrm{s}$, Time-to-Peak Acceleration $=1.6$ $\mathrm{ms}$, Time-to-Peak Velocity $=5.7 \mathrm{~ms}$.

Successful Test - All electronic data channels were present and continuous, data was successfully collected, desired test condition was achieved.

- Test 1065: Cell E1, Test 2; Red IMPAC Programmer; Drop Height $=25$ inch, Peak G level $=275.82$, Integrated Velocity Change $=13.35 \mathrm{ft} / \mathrm{s}$, Time-to-Peak Acceleration $=1.5$ $\mathrm{ms}$, Time-to-Peak Velocity $=5.6 \mathrm{~ms}$.

Successful Test - All electronic data channels were present and continuous, data was successfully collected, desired test condition was achieved.

- $\quad$ Test 1066: Cell E1, Test 3; Red IMPAC Programmer; Drop Height $=25$ inch, Peak G level $=268.62$, Integrated Velocity Change $=13.09 \mathrm{ft} / \mathrm{s}$, Time-to-Peak Acceleration $=1.6$ $\mathrm{ms}$, Time-to-Peak Velocity $=5.7 \mathrm{~ms}$.

Successful Test - All electronic data channels were present and continuous, data was successfully collected, desired test condition was achieved. 
- Test 1067: Cell G1, Test 1; Red IMPAC Programmer; Drop Height $=40$ inch, Peak G level $=377.6$, Integrated Velocity Change $=15.97 \mathrm{ft} / \mathrm{s}$, Time-to-Peak Acceleration $=1.5$ $\mathrm{ms}$, Time-to-Peak Velocity $=3.3 \mathrm{~ms}$.

Successful Test - All electronic data channels were present and continuous, data was successfully collected, desired test condition was achieved.

- Test 1068: Cell G1, Test 2; Red IMPAC Programmer; Drop Height $=40$ inch, Peak G level $=382.09$, Integrated Velocity Change $=16.08 \mathrm{ft} / \mathrm{s}$, Time-to-Peak Acceleration $=1.4$ $\mathrm{ms}$, Time-to-Peak Velocity $=3.3 \mathrm{~ms}$.

No Test- Accelerometer came loose on impact during 1067.

- Test 1069: Cell G1, Test 3; Red IMPAC Programmer; Drop Height $=40$ inch, Peak G level $=383.97$, Integrated Velocity Change $=16.7 \mathrm{ft} / \mathrm{s}$, Time-to-Peak Acceleration $=1.4$ ms, Time-to-Peak Velocity $=4.7 \mathrm{~ms}$.

Successful Test - All electronic data channels were present and continuous, data was successfully collected, desired test condition was achieved.

- Test 1070: Cell G1, Test 4; Red IMPAC Programmer; Drop Height $=40$ inch, Peak G level $=380.94$, Integrated Velocity Change $=16.6 \mathrm{ft} / \mathrm{s}$, Time-to-Peak Acceleration $=1.5$ $\mathrm{ms}$, Time-to-Peak Velocity $=3.3 \mathrm{~ms}$.

Successful Test - All electronic data channels were present and continuous, data was successfully collected, desired test condition was achieved.

- Test 1071: Cell E2, Test 1; Red IMPAC Programmer; Drop Height $=25$ inch, Peak G level $=268.03$, Integrated Velocity Change $=13.19 \mathrm{ft} / \mathrm{s}$, Time-to-Peak Acceleration $=2$ $\mathrm{ms}$, Time-to-Peak Velocity $=4.4 \mathrm{~ms}$.

Successful Test - All electronic data channels were present and continuous, data was successfully collected, desired test condition was achieved.

- Test 1072: Cell E2, Test 2; Red IMPAC Programmer; Drop Height $=25$ inch, Peak G level $=270.68$, Integrated Velocity Change $=13.3 \mathrm{ft} / \mathrm{s}$, Time-to-Peak Acceleration $=2$ $\mathrm{ms}$, Time-to-Peak Velocity $=4.4 \mathrm{~ms}$.

Successful Test - All electronic data channels were present and continuous, data was successfully collected, desired test condition was achieved.

- Test 1073: Cell E2, Test 3; Red IMPAC Programmer; Drop Height $=25$ inch, Peak G level $=268.46$, Integrated Velocity Change $=13.35 \mathrm{ft} / \mathrm{s}$, Time-to-Peak Acceleration $=1.6$ $\mathrm{ms}$, Time-to-Peak Velocity $=4.3 \mathrm{~ms}$.

Successful Test - All electronic data channels were present and continuous, data was successfully collected, desired test condition was achieved. 
- Test 1074: Cell H3, Test 1; Red IMPAC Programmer; Drop Height $=50$ inch, Peak G level $=581.71$, Integrated Velocity Change $=21.98 \mathrm{ft} / \mathrm{s}$, Time-to-Peak Acceleration $=1.3$ $\mathrm{ms}$, Time-to-Peak Velocity $=2.8 \mathrm{~ms}$.

Successful Test - All electronic data channels were present and continuous, data was successfully collected, desired test condition was achieved.

- Test 1075: Cell H3, Test 2; Red IMPAC Programmer; Drop Height $=50$ inch, Peak G level $=515.33$, Integrated Velocity Change $=20.26 \mathrm{ft} / \mathrm{s}$, Time-to-Peak Acceleration $=1.4$ $\mathrm{ms}$, Time-to-Peak Velocity $=4.3 \mathrm{~ms}$.

Successful Test - All electronic data channels were present and continuous, data was successfully collected, desired test condition was achieved.

- Test 1076: Cell H3, Test 3; Red IMPAC Programmer; Drop Height $=50$ inch, Peak G level $=538.95$, Integrated Velocity Change $=23.71 \mathrm{ft} / \mathrm{s}$, Time-to-Peak Acceleration $=2.5$ $\mathrm{ms}$, Time-to-Peak Velocity $=2.9 \mathrm{~ms}$.

Successful Test - All electronic data channels were present and continuous, data was successfully collected, desired test condition was achieved.

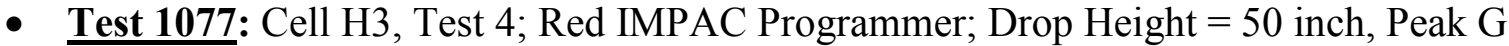
level $=455.75$, Integrated Velocity Change $=11.48 \mathrm{ft} / \mathrm{s}$, Time-to-Peak Acceleration $=1.4$ ms, Time-to-Peak Velocity $=1.7 \mathrm{~ms}$.

No Test- Loose connection occurred.

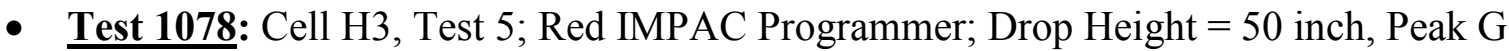
level $=489.72$, Integrated Velocity Change $=18.62 \mathrm{ft} / \mathrm{s}$, Time-to-Peak Acceleration $=1.5$ $\mathrm{ms}$, Time-to-Peak Velocity $=4.4 \mathrm{~ms}$.

Successful Test - All electronic data channels were present and continuous, data was successfully collected, desired test condition was achieved.

- Test 1079: Cell H3, Test 6; Red IMPAC Programmer; Drop Height $=50$ inch, Peak G level $=486.27$, Integrated Velocity Change $=18.74 \mathrm{ft} / \mathrm{s}$, Time-to-Peak Acceleration $=1.5$ $\mathrm{ms}$, Time-to-Peak Velocity $=5.1 \mathrm{~ms}$.

Successful Test - All electronic data channels were present and continuous, data was successfully collected, desired test condition was achieved. 


\section{APPENDIX C: SAMPLE DATA SHEETS - RED URETHANE PROGRAMMERS}

\section{Test 1061:}

Cell D1, Drop Height $=20$ inch, Peak G level $=213.46$, Integrated Velocity Change $=$ $11.62 \mathrm{ft} / \mathrm{s}$, Time-to-Peak Acceleration $=2.1 \mathrm{~ms}$, Time-to-Peak Velocity $=4.3 \mathrm{~ms}$.

Test 1075:

Cell H3, Drop Height $=50$ inch, Peak G level $=515.33$, Integrated Velocity Change $=$ $20.26 \mathrm{ft} / \mathrm{s}$, Time-to-Peak Acceleration $=1.4 \mathrm{~ms}$, Time-to-Peak Velocity $=4.3 \mathrm{~ms}$. 
201304 Test: 1061 Test Date: 130507 Subj: RED BUMPER Wt 0 Nom G: 2000 Cell: D1

\begin{tabular}{|c|c|c|c|c|c|}
\hline Data ID & $\begin{array}{l}\text { Immediate } \\
\text { Preimpact }\end{array}$ & $\begin{array}{l}\text { Maximum } \\
\text { Value }\end{array}$ & $\begin{array}{c}\text { Minimum } \\
\text { Value }\end{array}$ & $\begin{array}{c}\text { Time of } \\
\text { Maximum }\end{array}$ & $\begin{array}{l}\text { Time of } \\
\text { Minimum }\end{array}$ \\
\hline $\begin{array}{l}\text { Reference Mark Time (Ms) } \\
\text { Drop Height (In) } \\
\text { Impact Rise Time (Ms) } \\
\text { Impact Duration (Ms) } \\
\text { Velocity Change (Ft/Sec) }\end{array}$ & & 20.00 & & $\begin{array}{l}2.1 \\
4.4\end{array}$ & \\
\hline CARRIAGE XACCEL (G) & -0.01 & 23.09 & -15.53 & 3.0 & 1.1 \\
\hline CARRIAGE Y ACCEL (G) & 0.00 & 19.46 & -5.79 & 2.0 & 0.8 \\
\hline CARRIAGE Z ACCEL (G) & $-0,66$ & 21346 & -14.29 & 2.0 & 5.8 \\
\hline CARRIAGE RES ACCEL (G) & 0.66 & 213.66 & 0.33 & 2.0 & 14.4 \\
\hline INTEGRATED ACCEL (FTISEC) & 7.09 & 7.45 & -4.17 & 0.0 & 4.3 \\
\hline CARRIAGE X1 ACCEL (G) & -0.01 & 38.46 & -23.57 & 2.5 & 2.0 \\
\hline CARRIAGE Y1 ACCEL (G) & 0.01 & 17.82 & -18.23 & 2.0 & 2.5 \\
\hline CARRIAGE Z1 ACCEL (G) & -0.68 & 254.09 & -423.11 & 2.6 & 2.5 \\
\hline CARRIAGE RES1 ACCEL (G) & 0.68 & 423.24 & 021 & 2.5 & 39.5 \\
\hline CARRIAGE X2 ACCEL (G) & 0.00 & 108.58 & -5733 & 2.5 & 0.9 \\
\hline CARRIAGE Y2 ACCEL (G) & 000 & 22.03 & -26.30 & 27 & 2.5 \\
\hline CARRIAGE Z2 ACCEL (G) & -0.71 & 233.30 & -6.43 & 1.9 & 4.8 \\
\hline CARRIAGE RES2 ACCEL (G) & 0.71 & 235.08 & 0.02 & 2.0 & 49.3 \\
\hline & & & & & \\
\hline & & & & & \\
\hline & & & & & \\
\hline & & & & & \\
\hline & & & & & \\
\hline & & & & & \\
\hline & & & & & \\
\hline & & & & & \\
\hline & & & & & \\
\hline & & & & & \\
\hline
\end{tabular}

Page 1 of 1

54 
201304 Test 1061 Test Date: 130507 Subj: RED BUMPER Cell: D1

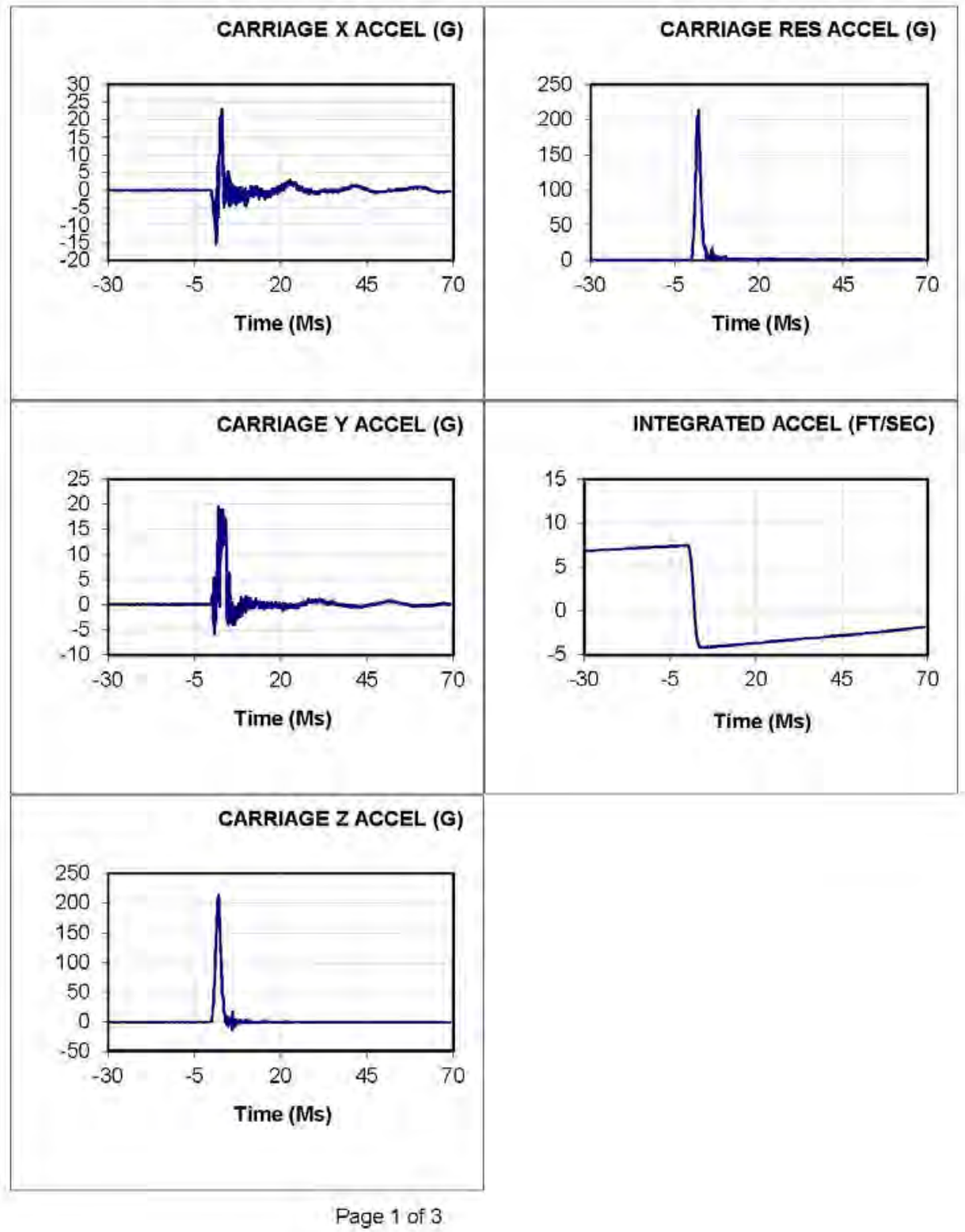

55 
201304 Test 1061 Test Date 130507 Subj: RED BUMPER Cell: D1

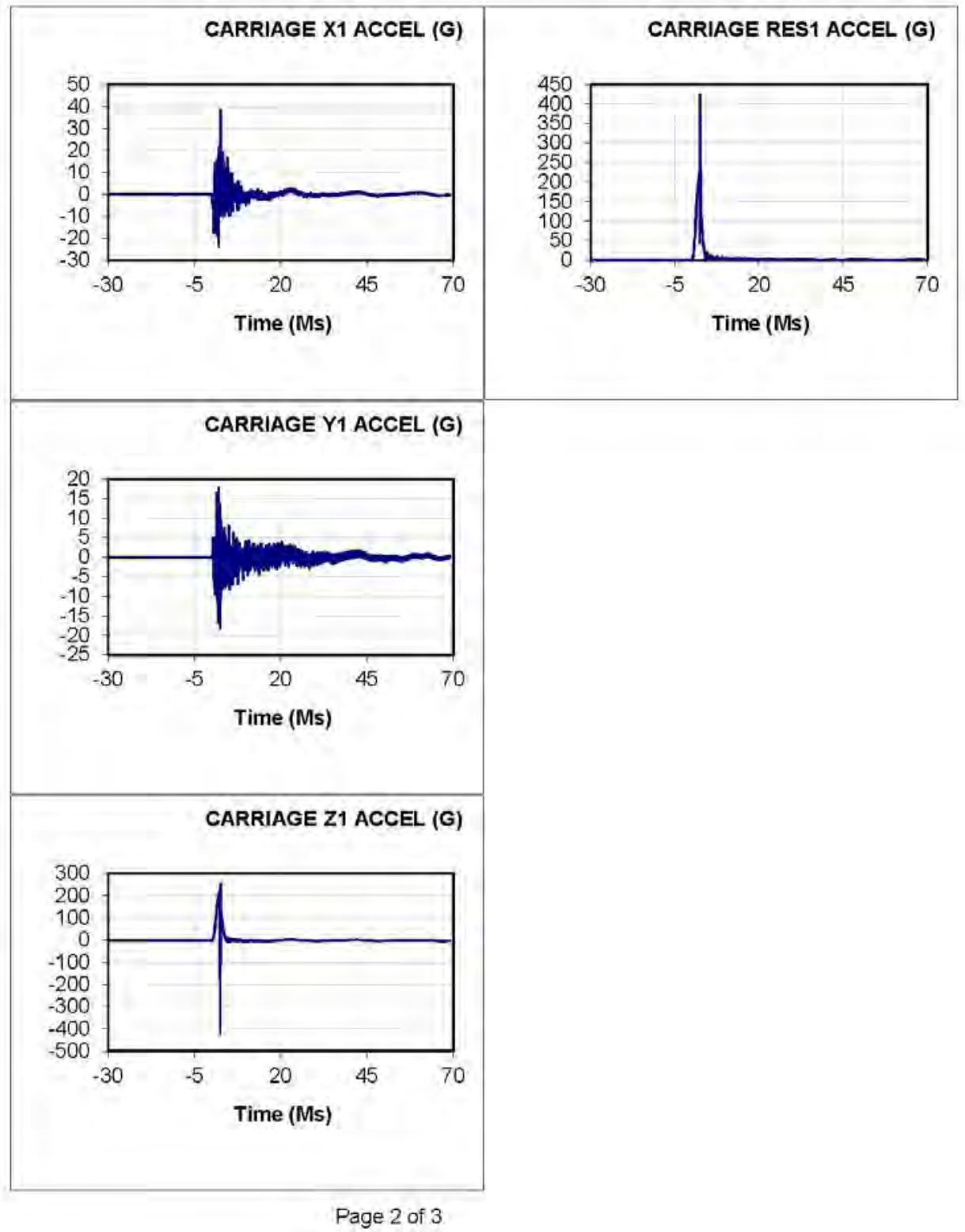


201304 Test 1061 Test Date 130507 Subj: RED BUMPER Cell: D1

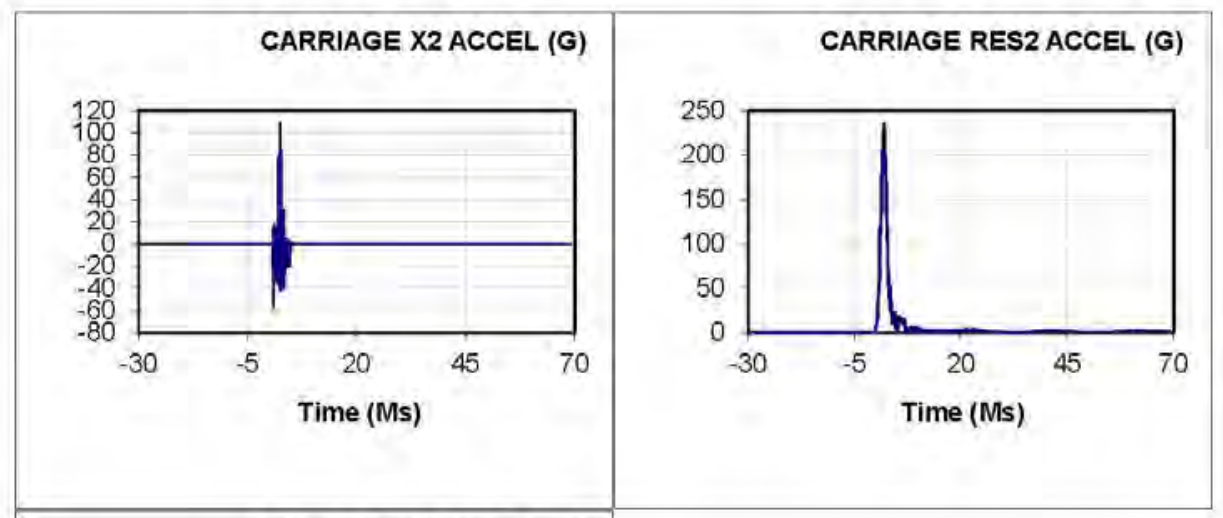

CARRIAGE Y2 ACCEL (G)

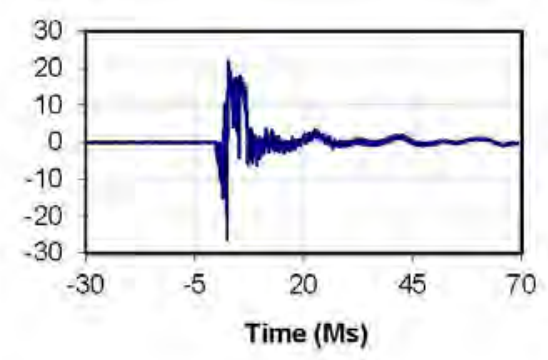

CARRIAGE Z2 ACCEL (G)

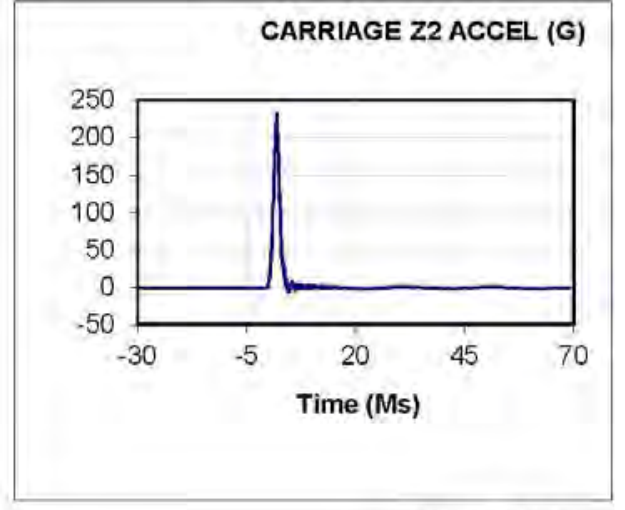

Page 3 of 3 
201304 Test: 1075 Test Date: 130507 Subj: RED BUMPER Wt: 250.0

Nom G 575.0 Cell: $\mathrm{H} 3$

\begin{tabular}{|c|c|c|c|c|c|}
\hline Data ID & $\begin{array}{l}\text { Immediate } \\
\text { Preimpact }\end{array}$ & $\begin{array}{c}\text { Maximum } \\
\text { Value }\end{array}$ & $\begin{array}{c}\text { Minimum } \\
\text { Value }\end{array}$ & $\begin{array}{c}\text { Time of } \\
\text { Maximum }\end{array}$ & $\begin{array}{l}\text { Time of } \\
\text { Minimum }\end{array}$ \\
\hline $\begin{array}{l}\text { Reference Mark Time (Ms) } \\
\text { Drop Height (In) } \\
\text { Impact Rise Time (Ms) } \\
\text { Impact Duration (Ms) } \\
\text { Velocity Change (Ft/Sec) }\end{array}$ & & 8000 & & $\begin{array}{l}1.4 \\
3.0\end{array}$ & \\
\hline CARRIAGE X ACCEL (G) & -0.02 & 63.07 & -51.86 & 1.8 & 2,6 \\
\hline CARRIAGE Y ACCEL (G) & 0.02 & 3789 & $-39,77$ & 0.4 & 1.8 \\
\hline CARRIAGE Z ACCEL (G) & -0.73 & 515,33 & $-40,60$ & 1.4 & 44 \\
\hline CARRIAGE RES ACCEL (G) & 0.73 & 515.80 & 0.17 & 1.4 & 35.6 \\
\hline INTEGRATED ACCEL (FT/SEC) & 11.90 & 12.29 & -7.97 & 0.0 & 4.3 \\
\hline CARRIAGE X1 ACCEL (G) & -0.01 & 34.85 & -37.97 & 3.8 & 2.1 \\
\hline CARRIAGE Y1 ACCEL (G) & 0.01 & 114.68 & -9477 & 1.9 & 2.2 \\
\hline CARRIAGE Z1 ACCEL (G) & -0.74 & 566,75 & -3836 & 1.6 & 2.7 \\
\hline CARRIAGE RES1 ACCEL (G) & 0.74 & 566.80 & 0.15 & 1.6 & 41.5 \\
\hline CARRIAGE X2 ACCEL (G) & 0,03 & 72.78 & -114.03 & 2.0 & 4.3 \\
\hline CARRIAGE Y2 ACCEL (G) & 0,00 & 59.61 & $-69,88$ & 1.6 & 4.6 \\
\hline CARRIAGE Z2 ACCEL (G) & -0.83 & 631.01 & -34.31 & 1.3 & 3,3 \\
\hline CARRIAGE RES2 ACCEL (G) & 0.84 & 633.63 & 0,17 & 1.3 & 55,0 \\
\hline & & & & & \\
\hline & & & & & \\
\hline & & & & & \\
\hline & & & & & \\
\hline & & & & & \\
\hline & & & & & \\
\hline & & & & & \\
\hline & & & & & \\
\hline & & & & & \\
\hline & & & & & \\
\hline
\end{tabular}

Page 1 of 1

58 
201304 Test 1075 Test Date 130507 Subj: RED BUMPER Cell: H3

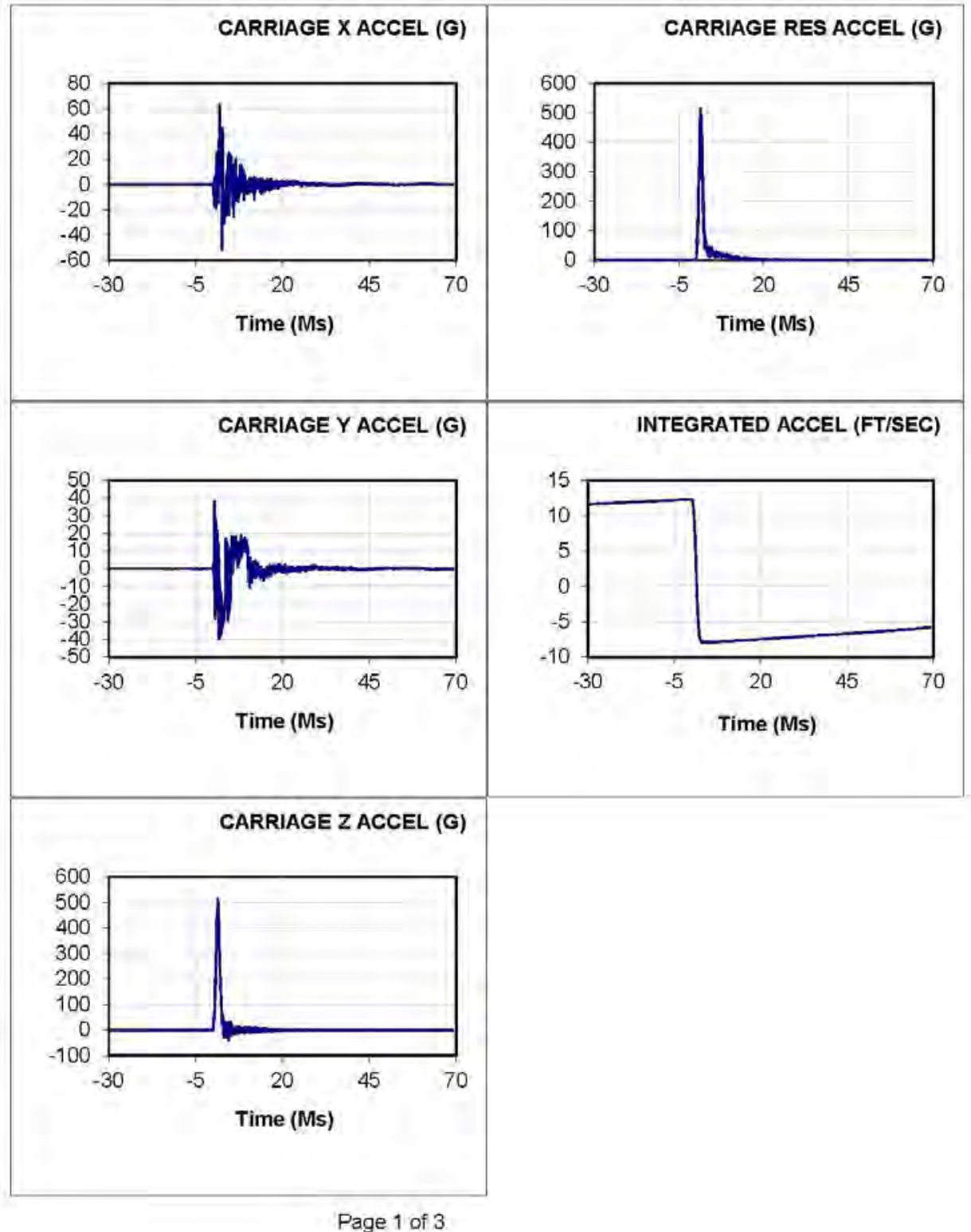

Page 1 of 3 
201304 Test 1075 Test Date 130507 Subj: RED BUMPER Cell: H3

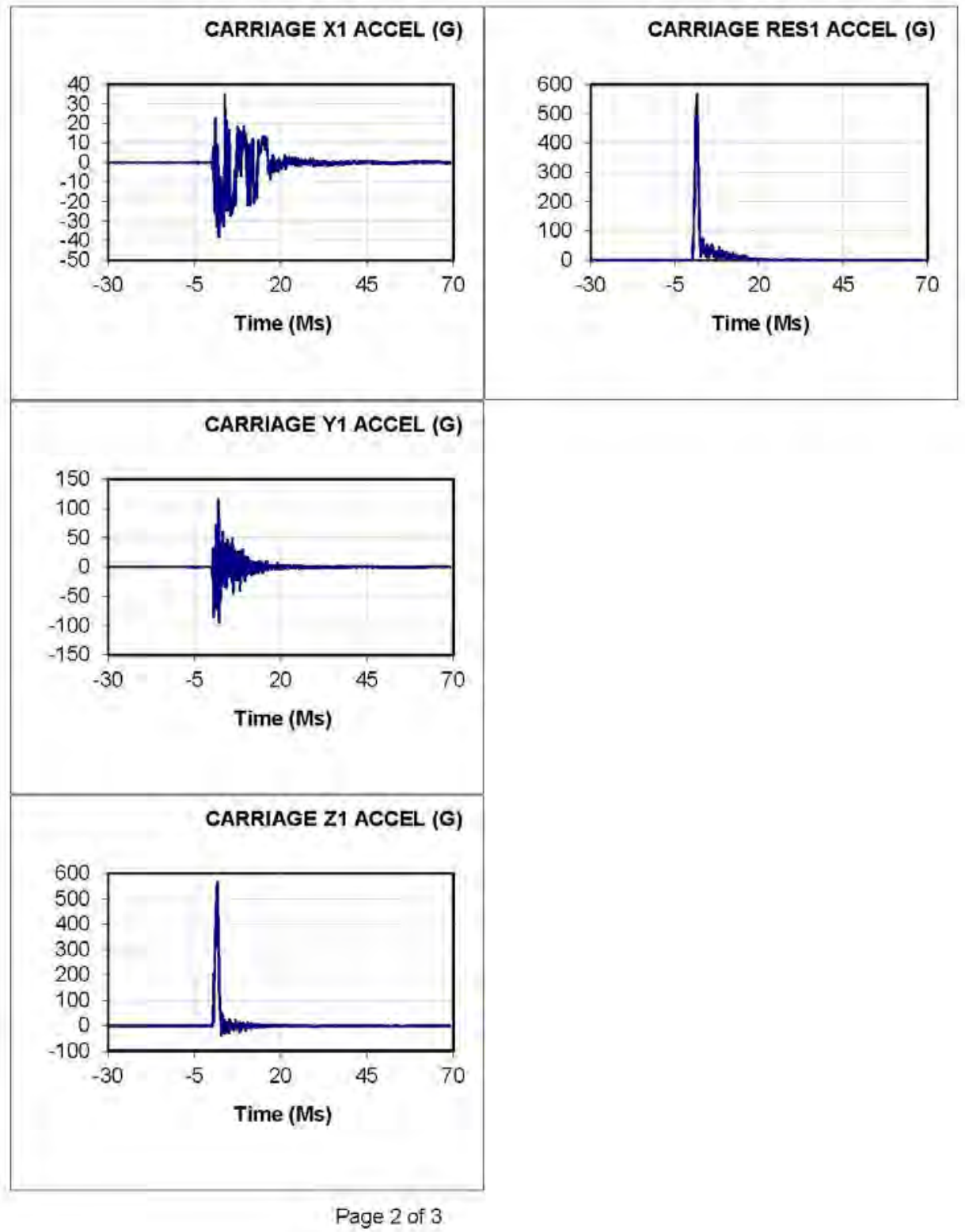


201304 Test 1075 Test Date 130507 Subj: RED BUMPER Cell: H3

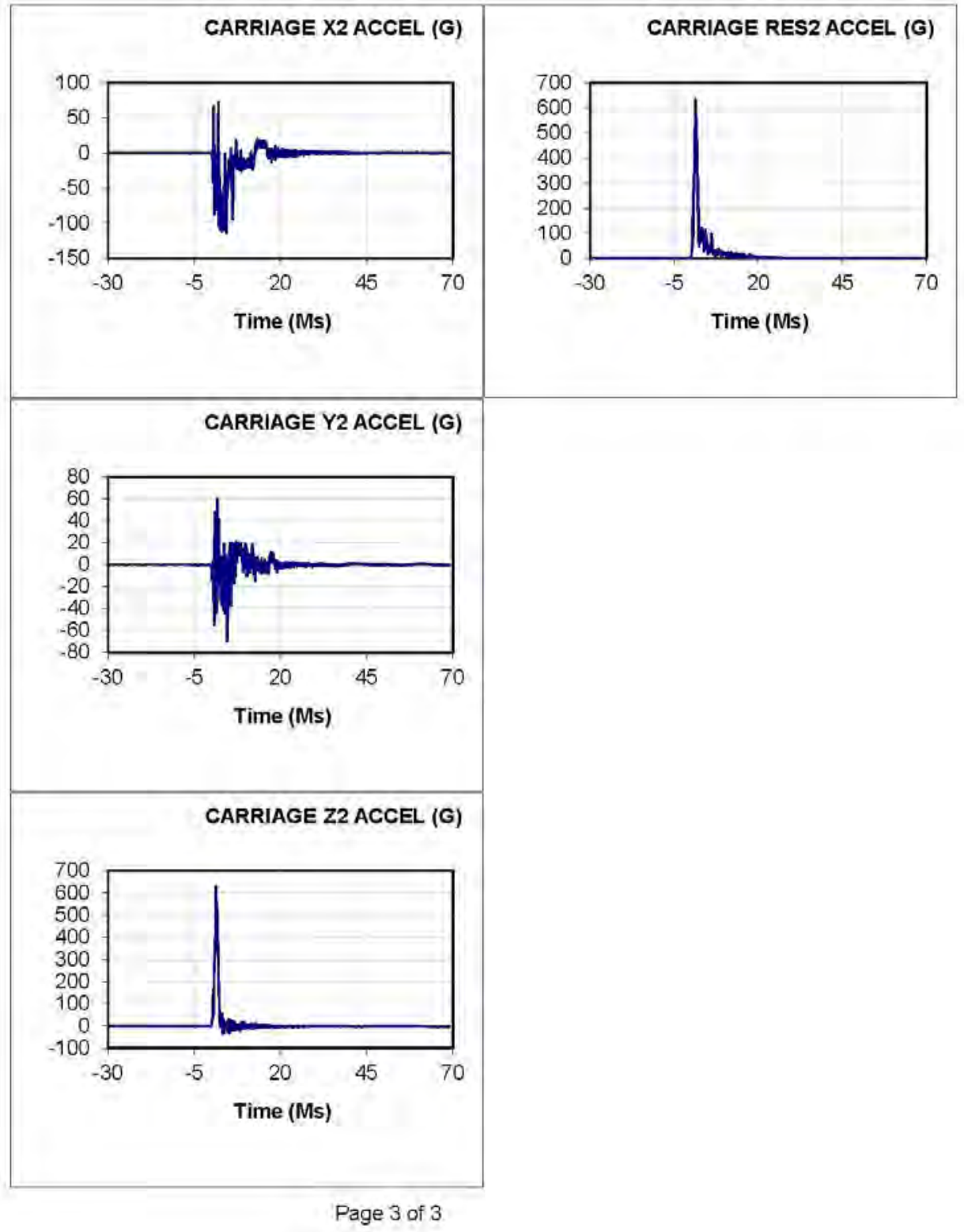

61 


\section{APPENDIX D. VID CHARACTERIZATION WITH FELT PROGRAMMERS (DENSITY VARIATION): TEST-BY-TEST SUMMARY}

- Test 1080: Cell I, Test 1; Felt Density 16S1 (0.50inch)/ Red IMPAC Programmer; Drop Height $=10$ inch, Peak $\mathrm{G}$ level $=65.97$, Integrated Velocity Change $=7.89 \mathrm{ft} / \mathrm{s}$, Time-toPeak Acceleration $=3.9 \mathrm{~ms}$, Time-to-Peak Velocity $=9.4 \mathrm{~ms}$.

Successful Test - All electronic data channels were present and continuous, data was successfully collected, desired test condition was achieved.

- $\quad$ Test 1081: Cell J, Test 1; Felt Density 20S1 (0.50inch)/ Red IMPAC Programmer; Drop Height $=10$ inch, Peak G level $=72.26$, Integrated Velocity Change $=8.01 \mathrm{ft} / \mathrm{s}$, Time-toPeak Acceleration $=3.6 \mathrm{~ms}$, Time-to-Peak Velocity $=8.3 \mathrm{~ms}$.

Successful Test - All electronic data channels were present and continuous, data was successfully collected, desired test condition was achieved.

- Test 1082: Cell K, Test 1; Felt Density 26S1 (0.50inch)/ Red IMPAC Programmer; Drop Height $=10$ inch, Peak G level $=73.75$, Integrated Velocity Change $=8.11 \mathrm{ft} / \mathrm{s}$, Time-toPeak Acceleration $=3.6 \mathrm{~ms}$, Time-to-Peak Velocity $=8.3 \mathrm{~ms}$.

Successful Test - All electronic data channels were present and continuous, data was successfully collected, desired test condition was achieved.

- Test 1083: Cell L, Test 1; Felt Density 32S1 (0.50inch)/ Red IMPAC Programmer; Drop Height $=10$ inch, Peak G level $=84.98$, Integrated Velocity Change $=8.39 \mathrm{ft} / \mathrm{s}$, Time-toPeak Acceleration $=3 \mathrm{~ms}$, Time-to-Peak Velocity $=3.9 \mathrm{~ms}$.

Successful Test - All electronic data channels were present and continuous, data was successfully collected, desired test condition was achieved.

- Test 1084: Cell I, Test 2; Felt Density 16S1 (0.50inch)/ Red IMPAC Programmer; Drop Height $=10$ inch, Peak G level $=70.69$, Integrated Velocity Change $=8.03 \mathrm{ft} / \mathrm{s}$, Time-toPeak Acceleration $=3.6 \mathrm{~ms}$, Time-to-Peak Velocity $=9.1 \mathrm{~ms}$.

Successful Test - All electronic data channels were present and continuous, data was successfully collected, desired test condition was achieved.

- Test 1085: Cell J, Test 2; Felt Density 20S1 (0.50inch)/ Red IMPAC Programmer; Drop Height $=10$ inch, Peak G level $=77.16$, Integrated Velocity Change $=8.18 \mathrm{ft} / \mathrm{s}$, Time-toPeak Acceleration $=3.3 \mathrm{~ms}$, Time-to-Peak Velocity $=8.6 \mathrm{~ms}$.

Successful Test - All electronic data channels were present and continuous, data was successfully collected, desired test condition was achieved.

- Test 1086: Cell K, Test 2; Felt Density 26S1 (0.50inch)/ Red IMPAC Programmer; Drop Height $=10$ inch, Peak G level $=77.68$, Integrated Velocity Change $=8.26 \mathrm{ft} / \mathrm{s}$, Time-toPeak Acceleration $=3.6 \mathrm{~ms}$, Time-to-Peak Velocity $=8.1 \mathrm{~ms}$. 
Successful Test - All electronic data channels were present and continuous, data was successfully collected, desired test condition was achieved.

- Test 1087: Cell L, Test 2; Felt Density 32S1 (0.50inch)/ Red IMPAC Programmer; Drop Height $=10$ inch, Peak $\mathrm{G}$ level $=88.14$, Integrated Velocity Change $=8.46 \mathrm{ft} / \mathrm{s}$, Time-toPeak Acceleration $=2.9 \mathrm{~ms}$, Time-to-Peak Velocity $=6.9 \mathrm{~ms}$.

Successful Test - All electronic data channels were present and continuous, data was successfully collected, desired test condition was achieved.

- Test 1088: Cell M, Test 1; Felt Density 16S1 (0.50inch)/ Red IMPAC Programmer; Drop Height $=40$ inch, Peak $\mathrm{G}$ level $=239.84$, Integrated Velocity Change $=15.9 \mathrm{ft} / \mathrm{s}$, Timeto-Peak Acceleration $=2.8 \mathrm{~ms}$, Time-to-Peak Velocity $=6.5 \mathrm{~ms}$.

Successful Test - All electronic data channels were present and continuous, data was successfully collected, desired test condition was achieved.

- Test 1089: Cell N, Test 1; Felt Density 20S1 (0.50inch)/ Red IMPAC Programmer; Drop Height $=40$ inch, Peak G level $=253.52$, Integrated Velocity Change $=16.07 \mathrm{ft} / \mathrm{s}$, Timeto-Peak Acceleration $=2.4 \mathrm{~ms}$, Time-to-Peak Velocity $=5.6 \mathrm{~ms}$.

Successful Test - All electronic data channels were present and continuous, data was successfully collected, desired test condition was achieved.

- $\quad$ Test 1090: Cell O, Test 1; Felt Density 26S1 (0.50inch)/ Red IMPAC Programmer; Drop Height $=40$ inch, Peak G level $=247.92$, Integrated Velocity Change $=16.13 \mathrm{ft} / \mathrm{s}$, Timeto-Peak Acceleration $=2.5 \mathrm{~ms}$, Time-to-Peak Velocity $=5.4 \mathrm{~ms}$.

Successful Test - All electronic data channels were present and continuous, data was successfully collected, desired test condition was achieved.

- Test 1091: Cell P, Test 1; Felt Density 32S1 (0.50inch)/ Red IMPAC Programmer; Drop Height $=40$ inch, Peak G level $=274.51$, Integrated Velocity Change $=16.63 \mathrm{ft} / \mathrm{s}$, Timeto-Peak Acceleration $=2 \mathrm{~ms}$, Time-to-Peak Velocity $=4.9 \mathrm{~ms}$.

Successful Test - All electronic data channels were present and continuous, data was successfully collected, desired test condition was achieved.

- Test 1092: Cell M, Test 2; Felt Density 16S1 (0.50inch)/ Red IMPAC Programmer; Drop Height $=40$ inch, Peak G level $=258.37$, Integrated Velocity Change $=16.18 \mathrm{ft} / \mathrm{s}$, Timeto-Peak Acceleration $=2.5 \mathrm{~ms}$, Time-to-Peak Velocity $=6.1 \mathrm{~ms}$.

Successful Test - All electronic data channels were present and continuous, data was successfully collected, desired test condition was achieved.

- Test 1093: Cell N, Test 2; Felt Density 20S1 (0.50inch)/ Red IMPAC Programmer; Drop Height $=40$ inch, Peak G level $=268.97$, Integrated Velocity Change $=16.26 \mathrm{ft} / \mathrm{s}$, Timeto-Peak Acceleration $=2.4 \mathrm{~ms}$, Time-to-Peak Velocity $=5.3 \mathrm{~ms}$. 
Successful Test - All electronic data channels were present and continuous, data was successfully collected, desired test condition was achieved.

- $\quad$ Test 1094: Cell O, Test 2; Felt Density 26S1 (0.50inch)/ Red IMPAC Programmer; Drop Height $=40$ inch, Peak G level $=265.84$, Integrated Velocity Change $=16.38 \mathrm{ft} / \mathrm{s}$, Timeto-Peak Acceleration $=2.3 \mathrm{~ms}$, Time-to-Peak Velocity $=7.4 \mathrm{~ms}$.

No Test - Freefall was not achieved; proper integrated velocity was unable to be recorded.

- Test 1095: Cell P, Test 2; Felt Density 32S1 (0.50inch)/ Red IMPAC Programmer; Drop Height $=40$ inch, Peak G level $=284.76$, Integrated Velocity Change $=16.67 \mathrm{ft} / \mathrm{s}$, Timeto-Peak Acceleration $=2 \mathrm{~ms}$, Time-to-Peak Velocity $=4.9 \mathrm{~ms}$.

Successful Test - All electronic data channels were present and continuous, data was successfully collected, desired test condition was achieved.

- Test 1096: Cell O, Test 3; Felt Density 26S1 (0.50inch)/ Red IMPAC Programmer; Drop Height $=40$ inch, Peak G level $=271.16$, Integrated Velocity Change $=16.31 \mathrm{ft} / \mathrm{s}$, Timeto-Peak Acceleration $=2.3 \mathrm{~ms}$, Time-to-Peak Velocity $=5.3 \mathrm{~ms}$.

Successful Test - All electronic data channels were present and continuous, data was successfully collected, desired test condition was achieved; Flip felt for retest. 


\section{APPENDIX E: SAMPLE DATA SHEETS - FELT PROGRAMMERS (DENSITY VARIATION)}

Test 1088: Cell M, Felt Density 16S1 (0.50 inch); Drop Height $=40$ inch, Peak G level = 239.84 , Integrated Velocity Change $=15.9 \mathrm{ft} / \mathrm{s}$, Time-to-Peak Acceleration $=2.8 \mathrm{~ms}$, Timeto-Peak Velocity $=6.5 \mathrm{~ms}$.

Test 1089: Cell N, Felt Density 20S1 (0.50 inch); Drop Height $=40$ inch, Peak G level $=$ 253.52, Integrated Velocity Change $=16.07 \mathrm{ft} / \mathrm{s}$, Time-to-Peak Acceleration $=2.4 \mathrm{~ms}$, Timeto-Peak Velocity $=5.6 \mathrm{~ms}$.

Test 1090: Cell O, Felt Density 26S1 (0.50 inch); Drop Height $=40$ inch, Peak G level $=$ 247.92 , Integrated Velocity Change $=16.13 \mathrm{ft} / \mathrm{s}$, Time-to-Peak Acceleration $=2.5 \mathrm{~ms}$, Timeto-Peak Velocity $=5.4 \mathrm{~ms}$.

Test 1091: Cell P, Felt Density 32S1 (0.50 inch); Drop Height $=40$ inch, Peak G level = 274.51 , Integrated Velocity Change $=16.63 \mathrm{ft} / \mathrm{s}$, Time-to-Peak Acceleration $=2 \mathrm{~ms}$, Timeto-Peak Velocity $=4.9 \mathrm{~ms}$. 
201304 Test: 1088 Test Date: 130514 Subj: 1651 Wt. 0 Nom G:250.0 Cell: $M$

\begin{tabular}{|c|c|c|c|c|c|}
\hline Data ID & $\begin{array}{l}\text { Immediate } \\
\text { Preimpact }\end{array}$ & $\begin{array}{c}\text { Maximum } \\
\text { Value }\end{array}$ & $\begin{array}{c}\text { Minimum } \\
\text { Value }\end{array}$ & $\begin{array}{l}\text { Time of } \\
\text { Maximum }\end{array}$ & $\begin{array}{l}\text { Time of } \\
\text { Minimum }\end{array}$ \\
\hline $\begin{array}{l}\text { Reference Mark Time (Ms) } \\
\text { Drop Height (In) } \\
\text { Impact Rise Time (Ms) } \\
\text { Impact Duration (Ms) } \\
\text { Velocity Change (Ft/Sec) }\end{array}$ & & 4000 & & $\begin{array}{l}2.8 \\
5.9\end{array}$ & \\
\hline CARRIAGE X ACCEL (G) & -0.01 & 15.77 & $-10,79$ & 3.2 & 1.7 \\
\hline CARRIAGE Y ACCEL (G) & 0.01 & 2.44 & -493 & 76 & 3.3 \\
\hline CARRIAGEZ ACCEL (G) & -0.67 & 239.84 & -6.74 & 28 & 68 \\
\hline CARRIAGE RES ACCEL (G) & 0.67 & 239.90 & 0.22 & 2.8 & 19.8 \\
\hline INTEGRATED ACCEL (FT/SEC) & 9.19 & 9.53 & -6.37 & 0.0 & 6.5 \\
\hline CARRIAGE X1 ACCEL (G) & -0.01 & 13.04 & -12.78 & 3.2 & 1.7 \\
\hline CARRIAGE Y1 ACCEL (G) & 0,02 & 1102 & -12.80 & 3,4 & 4.0 \\
\hline CARRIAGE Z1 ACCEL (G) & -0.72 & 246.79 & -454 & 27 & 16.4 \\
\hline CARRIAGE RES1 ACCEL (G) & 0.72 & 246.86 & 0.23 & 2.7 & 40.9 \\
\hline CARRIAGE X2 ACCEL (G) & 0,03 & 8.79 & -14.43 & 4.7 & 4.3 \\
\hline CARRIAGE Y2 ACCEL (G) & 0.01 & 11.01 & -13.76 & 1.8 & 3.4 \\
\hline CARRIAGE Z2 ACCEL (G) & -0.76 & 26154 & $-6,35$ & 27 & 94 \\
\hline CARRIAGE RES2 ACCEL (G) & 0,76 & 26161 & 0.21 & 27 & 33,8 \\
\hline & & & & & \\
\hline & & & & & \\
\hline & & & & & \\
\hline & & & & & \\
\hline & & & & & \\
\hline & & & & & \\
\hline & & & & & \\
\hline & & & & & \\
\hline & & & & & \\
\hline & & & & & \\
\hline
\end{tabular}

Page 1 of 1

66 
201304 Test: 1088 Test Date: 130514 Subj: 1651 Cell: M

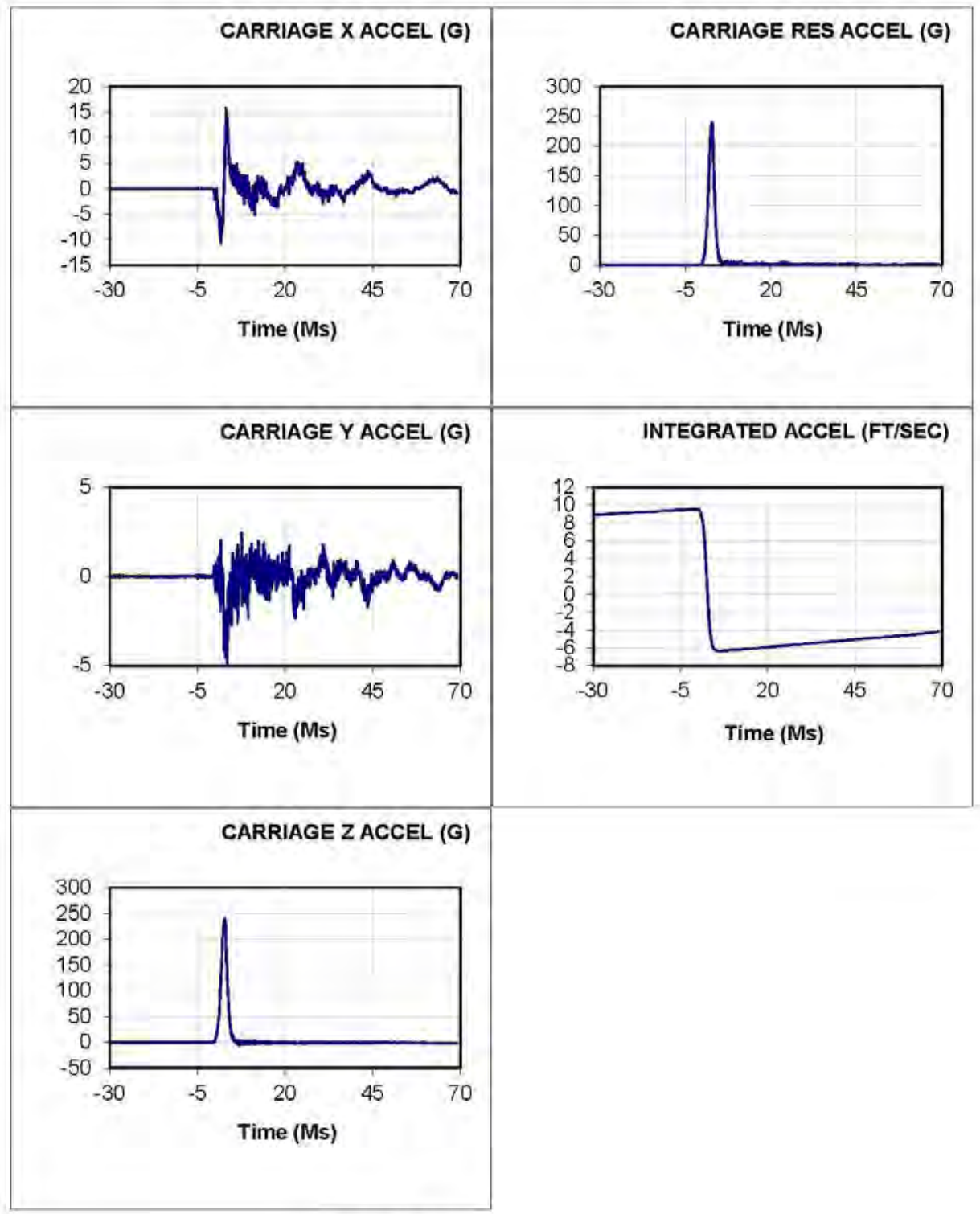

Page 1 of 3 
201304 Test: 1088 Test Date: 130514 Subj: 1651 Cell: M

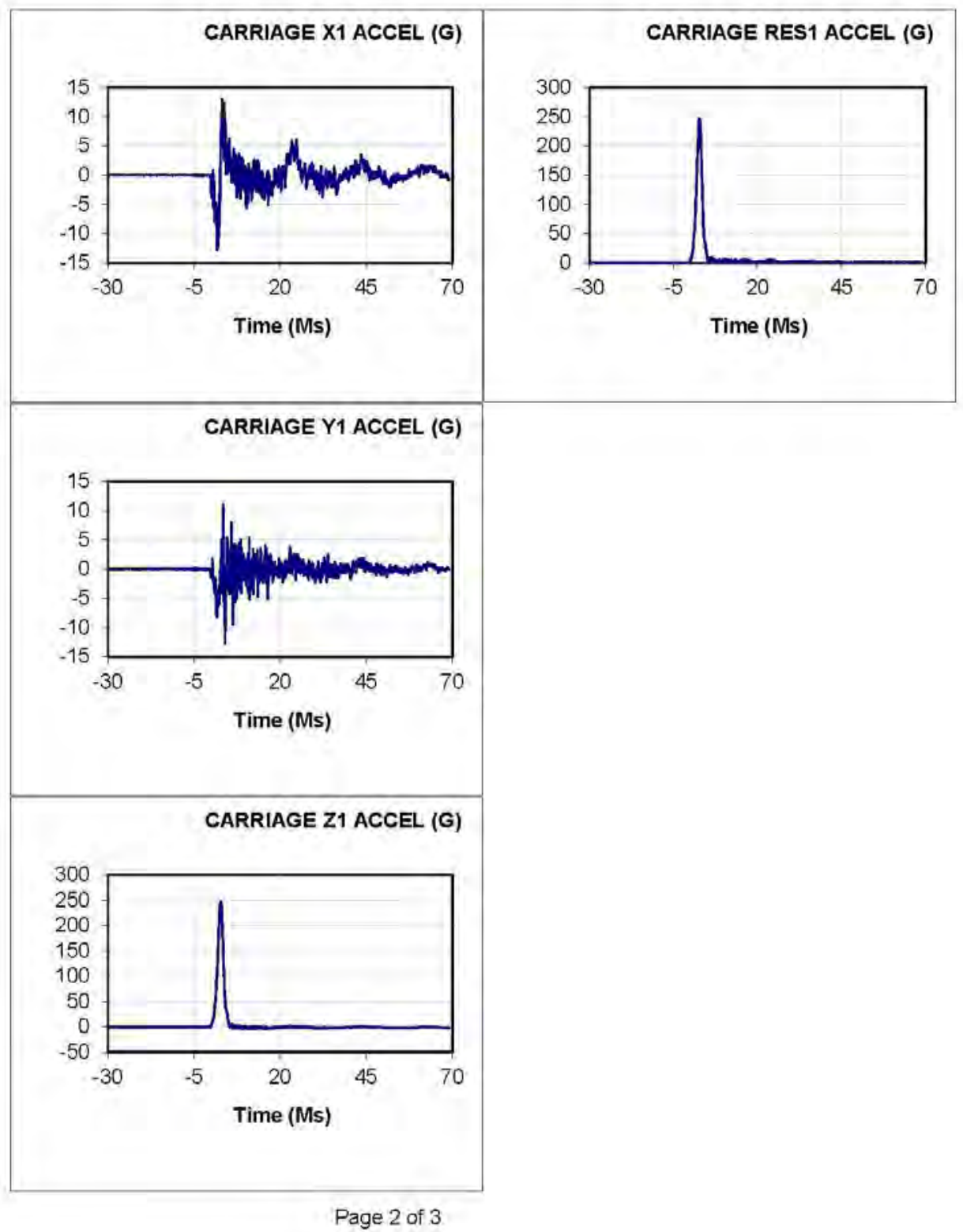


201304 Test: 1088 Test Date: 130514 Subj: 1651 Cell: M

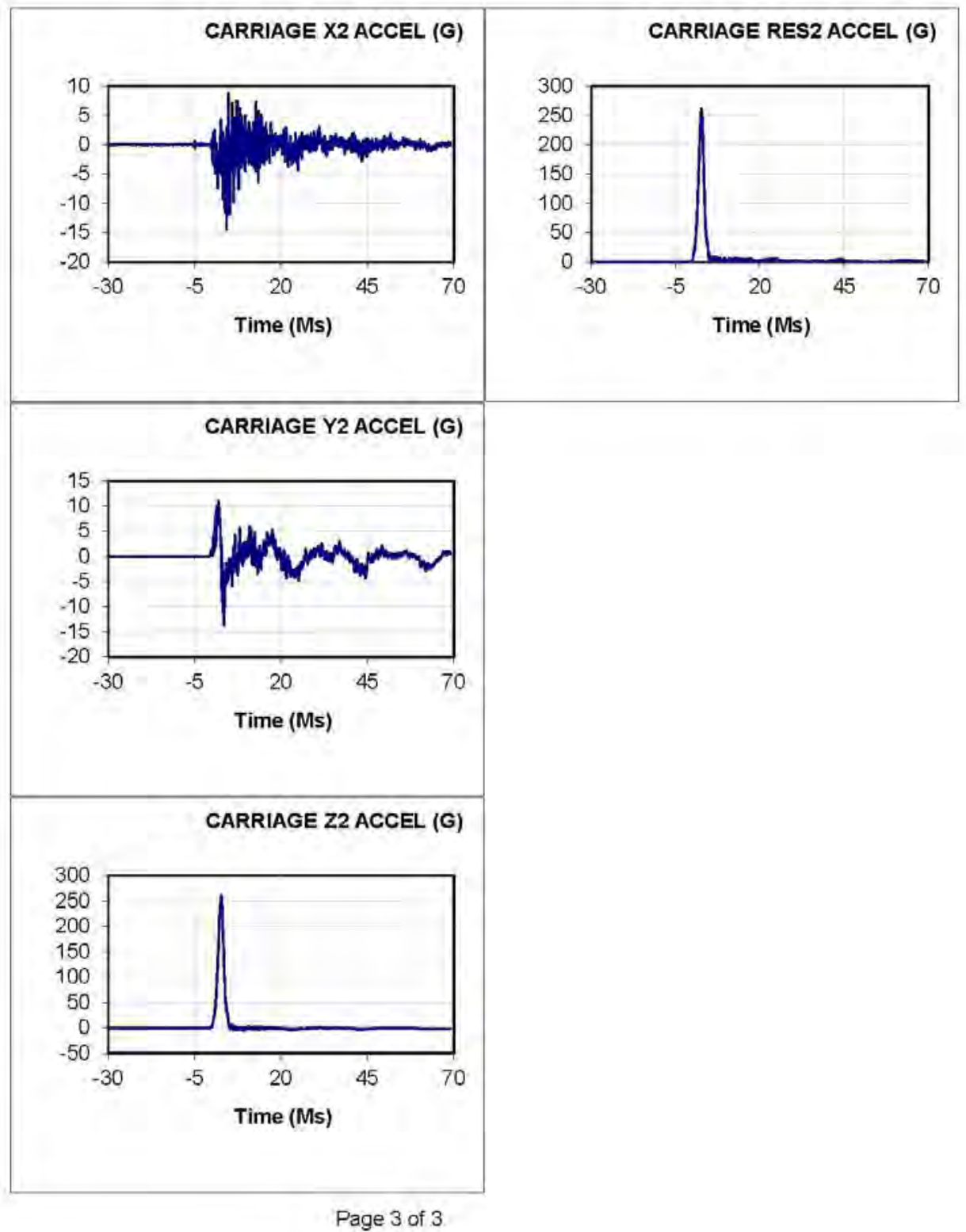


201304 Test: 1089 Test Date: 130514 Subj: 2051 Wt .0

Nom G: 250.0 Cell: $N$

\begin{tabular}{|c|c|c|c|c|c|}
\hline $\begin{array}{r}\text { Data ID } \\
\end{array}$ & \begin{tabular}{l|} 
Immediate \\
Preimpact
\end{tabular} & $\begin{array}{c}\text { Maximum } \\
\text { Value }\end{array}$ & $\begin{array}{l}\text { Minimum } \\
\text { Value }\end{array}$ & $\begin{array}{c}\text { Time Of } \\
\text { Maximum }\end{array}$ & $\begin{array}{l}\text { Time of } \\
\text { Minimum }\end{array}$ \\
\hline $\begin{array}{l}\text { Reference Mark Time (Ms) } \\
\text { Drop Height (In) } \\
\text { Impact Rise Time (Ms) } \\
\text { Impact Duration (Ms) } \\
\text { Velocity Change (Ft/Sec) }\end{array}$ & & 4000 & & $\begin{array}{l}24 \\
5.6\end{array}$ & \\
\hline CARRIAGE X ACCEL (G) & -0.02 & 9.67 & -4.80 & 3.2 & 1.5 \\
\hline CARRIAGE Y ACCEL (G) & 0.00 & 2.65 & -942 & 13 & 20 \\
\hline CARRIAGEZ ACCEL (G) & -0.72 & 25352 & -6.26 & 23 & 70 \\
\hline CARRIAGE RES ACCEL (G) & 0.72 & 253.58 & 0.37 & 2.3 & 18.0 \\
\hline INTEGRATED ACCEL (FT/SEC) & 9.89 & 10.27 & -5.80 & 0.0 & 5.6 \\
\hline CARRIAGE X1 ACCEL (G) & -0.01 & 12.26 & -7.14 & 2.8 & 2.1 \\
\hline CARRIAGE Y1 ACCEL (G) & 0.02 & 586 & -10.72 & 43 & 39 \\
\hline CARRIAGE Z1 ACCEL (G) & -0.72 & 265.27 & -521 & 25 & 6.8 \\
\hline CARRIAGE RES1 ACCEL (G) & 0.72 & 265.39 & 0.24 & 2.5 & 22.0 \\
\hline CARRIAGE X2 ACCEL (G) & 0.02 & 6.51 & -15.97 & 5.7 & 1.9 \\
\hline CARRIAGE Y 2 ACCEL (G) & 0.00 & 1030 & -9.74 & 2.0 & 3.3 \\
\hline CARRIAGE Z2 ACCEL (G) & -076 & 27308 & -4.29 & 25 & 66 \\
\hline CARRIAGE RES2 ACCEL (G) & 0,76 & 273,12 & 0.05 & 25 & 17.7 \\
\hline & & & & & \\
\hline & & & & & \\
\hline & & & & & \\
\hline & & & & & \\
\hline & & & & & \\
\hline & & & & & \\
\hline & & & & & \\
\hline & & & & & \\
\hline & & & & & \\
\hline & & & & & \\
\hline
\end{tabular}

Page 1 of 1

70 
201304 Test: 1089 Test Date: 130514 Subj. 2051 Cell: N

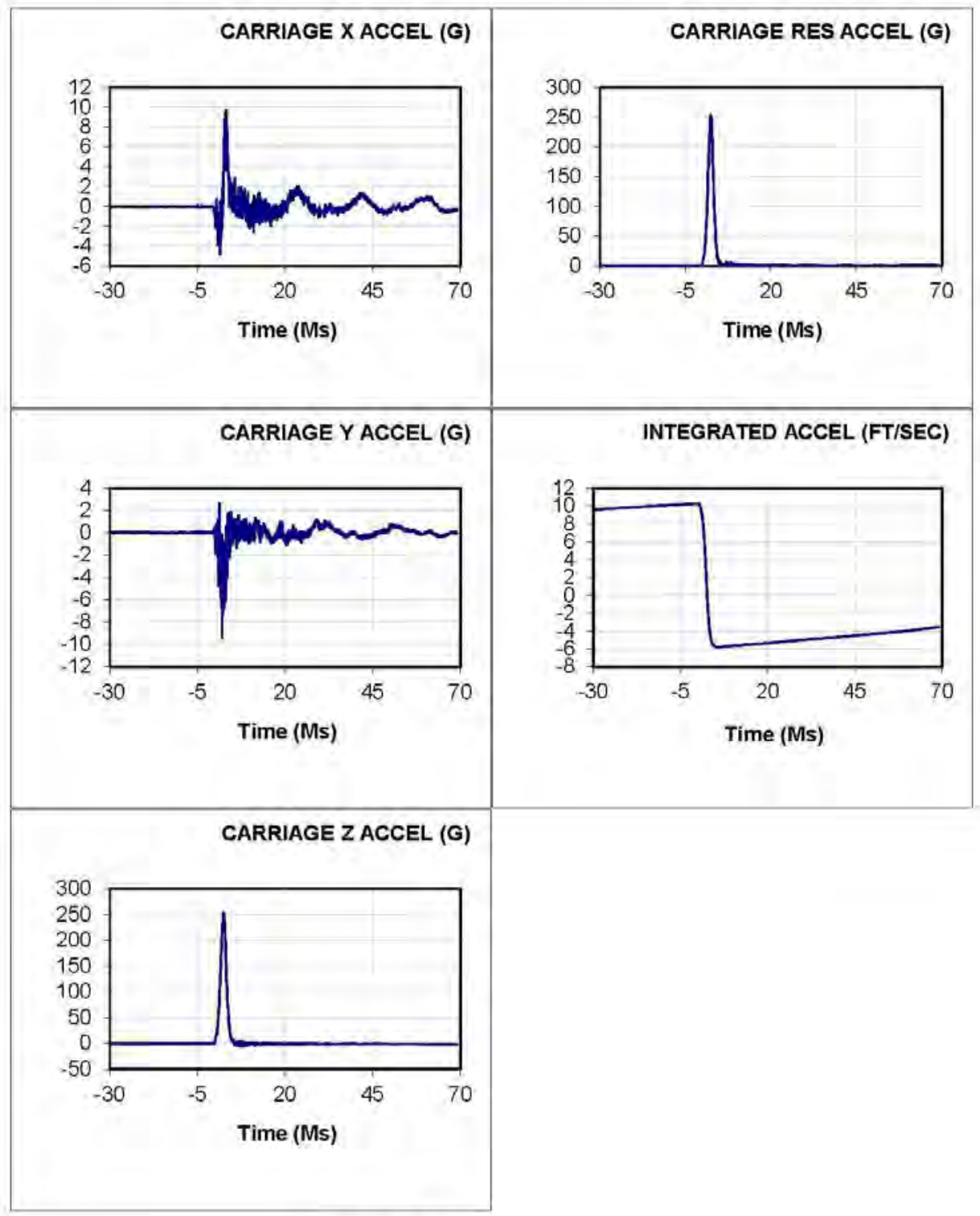

Page 1 of 3 
201304 Test: 1089 Test Date: 130514 Subj: 2051 Cell: N

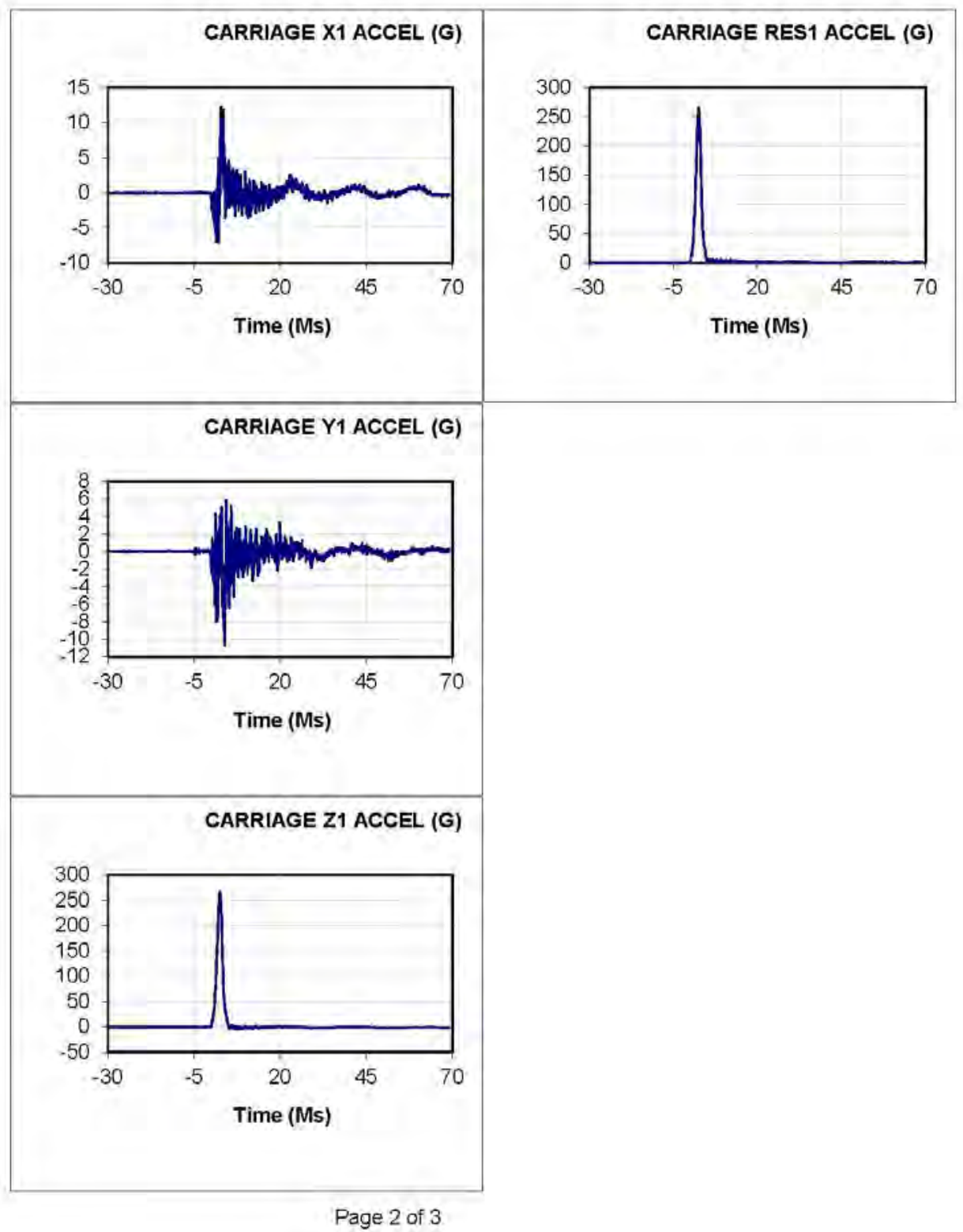

72 
201304 Test: 1089 Test Date: 130514 Subj: 2051 Cell: N

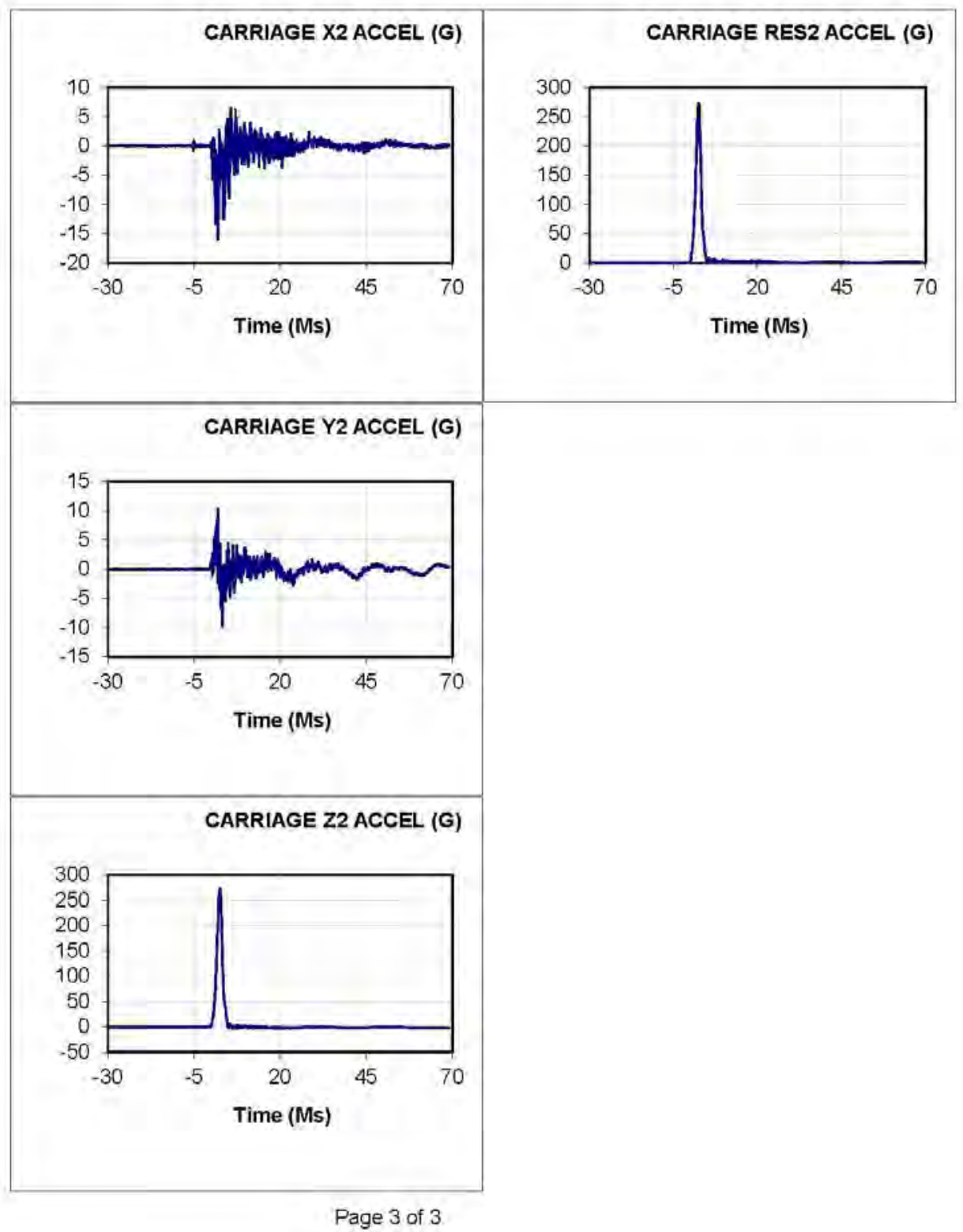

73 
201304 Test: 1090 Test Date: 130514 Subj: 2651 Wt. 0

Nom G: 250.0 Cell: 0

\begin{tabular}{|c|c|c|c|c|c|}
\hline Data ID & $\begin{array}{l}\text { Immediate } \\
\text { Preimpact }\end{array}$ & $\begin{array}{l}\text { Maximum } \\
\text { Value }\end{array}$ & $\begin{array}{l}\text { Minimum } \\
\text { Value }\end{array}$ & $\begin{array}{c}\text { Time of } \\
\text { Maximum }\end{array}$ & $\begin{array}{l}\text { Time of } \\
\text { Minimum }\end{array}$ \\
\hline $\begin{array}{l}\text { Reference Mark Time (Ms) } \\
\text { Drop Height (In) } \\
\text { Impact Rise Time (Ms) } \\
\text { Impact Duration (Ms) } \\
\text { Velocity Change (Ft/Sec) }\end{array}$ & & 4000 & & $\begin{array}{l}2.5 \\
5.4\end{array}$ & \\
\hline CARRIAGE X ACCEL (G) & -0.02 & 13.43 & $-13,31$ & 3.2 & 1.5 \\
\hline CARRIAGE Y ACCEL (G) & 0.01 & 365 & -942 & 41 & 20 \\
\hline CARRIAGE Z ACCEL (G) & -0.72 & 24792 & $-8,02$ & 25 & 77 \\
\hline CARRIAGE RES ACCEL (G) & 0.72 & 248.11 & 0.43 & 2.5 & 38.5 \\
\hline INTEGRATED ACCEL (FT/SEC) & 9.82 & 10.20 & -5.93 & 0.0 & 5.4 \\
\hline CARRIAGE X1 ACCEL (G) & -0.01 & 13.43 & -15.02 & 2.8 & 1.5 \\
\hline CARRIAGE Y1 ACCEL (G) & 0.02 & 8.91 & $-9,59$ & 28 & 1.0 \\
\hline CARRIAGE Z1 ACCEL (G) & -0.72 & 265.99 & -6.24 & 25 & 8.8 \\
\hline CARRIAGE RES1 ACCEL (G) & 0.72 & 266.03 & 0.23 & 2.5 & 5.7 \\
\hline CARRIAGE X2 ACCEL (G) & 0,02 & 8.14 & -18.19 & 5.7 & 1.9 \\
\hline CARRIAGE Y2 ACCEL (G) & 0.01 & 14.70 & $-11,33$ & 1.9 & 3.3 \\
\hline CARRIAGE Z2 ACCEL (G) & -0.80 & 26239 & $-5,11$ & 26 & 19,0 \\
\hline CARRIAGE RES2 ACCEL (G) & 0,80 & 262.40 & 0.15 & 26 & 33,8 \\
\hline & & & & & \\
\hline & & & & & \\
\hline & & & & & \\
\hline & & & & & \\
\hline & & & & & \\
\hline & & & & & \\
\hline & & & & & \\
\hline & & & & & \\
\hline & & & & & \\
\hline & & & & & \\
\hline
\end{tabular}

Page 1 of 1

74 
201304 Test: 1090 Test Date: 130514 Subj: 2651 Cell: 0

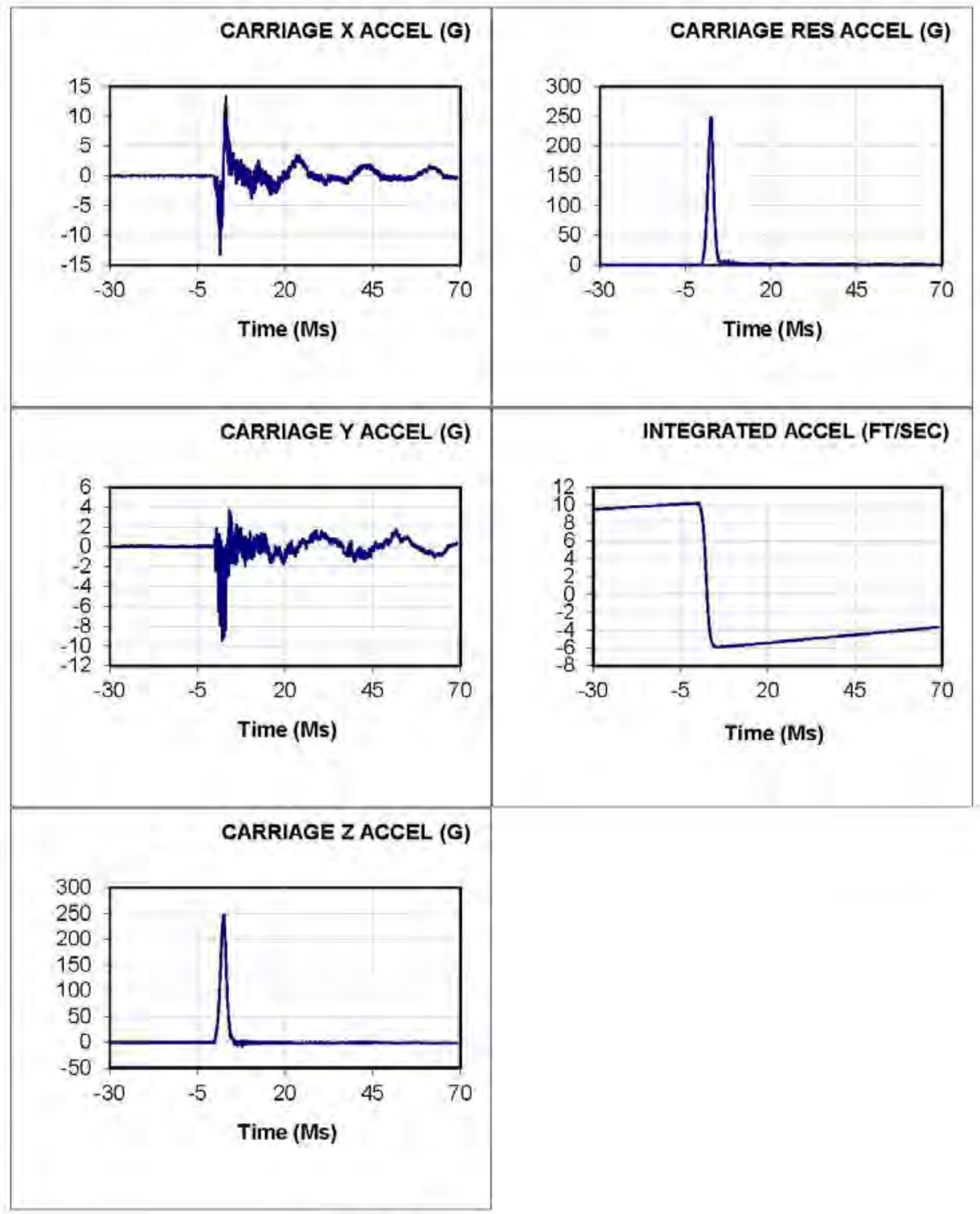

Page 1 of 3 
201304 Test: 1090 Test Date: 130514 Subj: 2651 Cell: 0

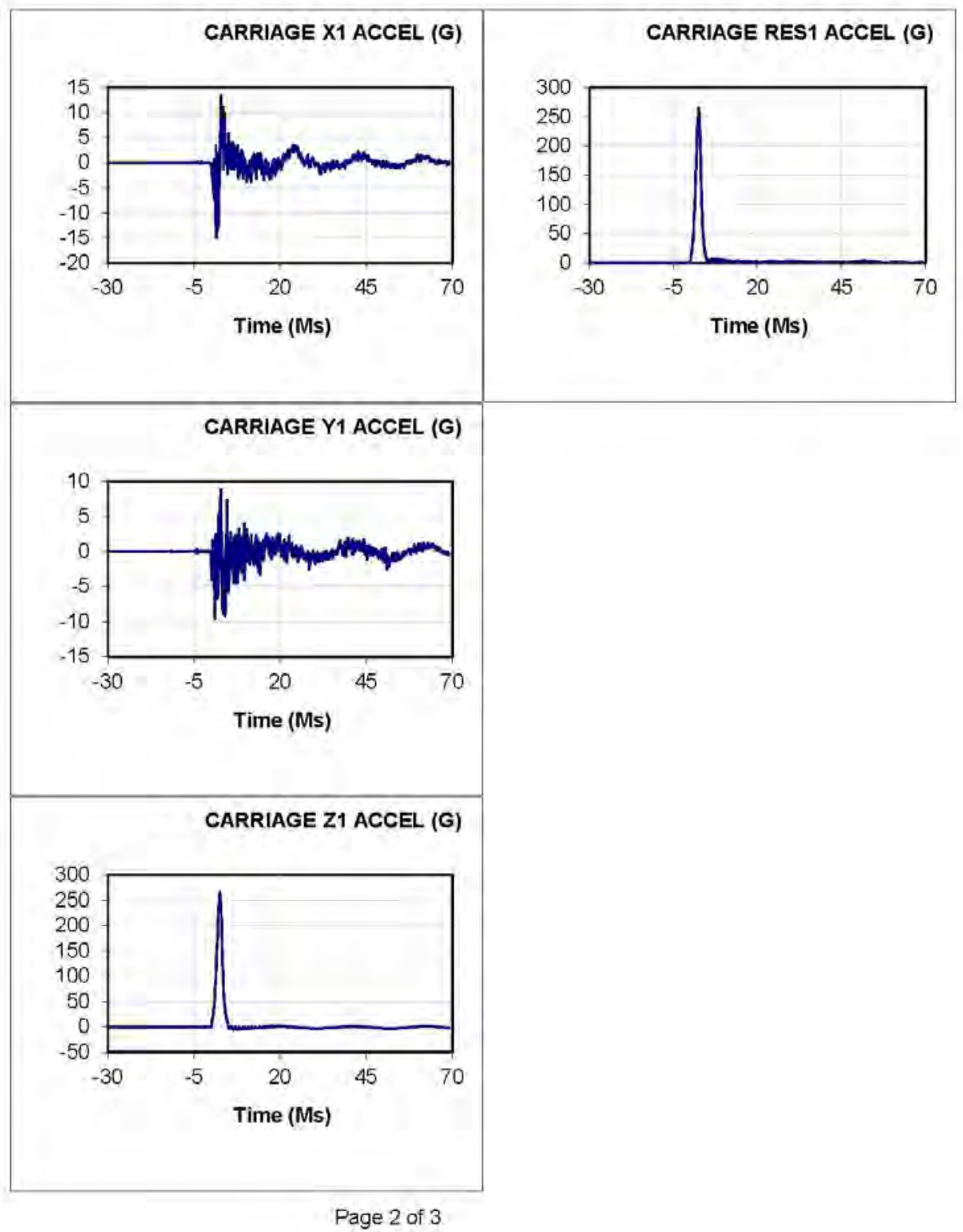


201304 Test: 1090 Test Date: 130514 Subj: 2651 Cell: 0

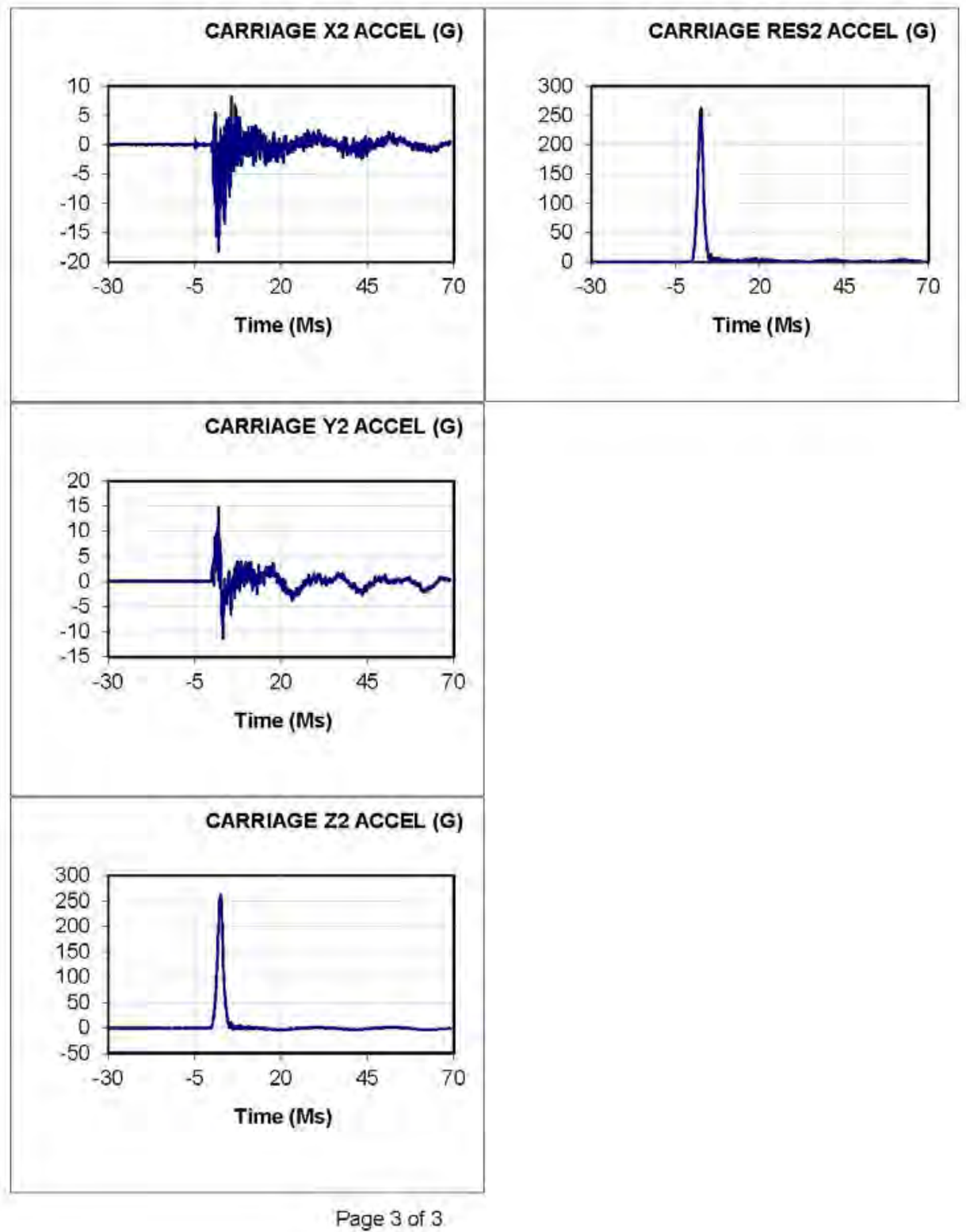


201304 Test: 1091 Test Date: 130514 Subj: 3251 Wt .0

Nom G: 250.0 Cell: P

\begin{tabular}{|c|c|c|c|c|c|}
\hline Data ID & $\begin{array}{l}\text { Immediate } \\
\text { Preimpact }\end{array}$ & $\begin{array}{l}\text { Maximum } \\
\text { Value }\end{array}$ & $\begin{array}{l}\text { Minimum } \\
\text { Value }\end{array}$ & $\begin{array}{c}\text { Time of } \\
\text { Maximum }\end{array}$ & $\begin{array}{c}\text { Time of } \\
\text { Minimum }\end{array}$ \\
\hline $\begin{array}{l}\text { Reference Mark Time (Ms) } \\
\text { Drop Height (In) } \\
\text { Impact Rise Time (Ms) } \\
\text { Impact Duration (Ms) } \\
\text { Velocity Change (Ft/Sec) }\end{array}$ & & 4000 & & $\begin{array}{l}2.0 \\
4.5\end{array}$ & \\
\hline CARRIAGE X ACCEL (G) & -0.02 & 11.28 & -9.92 & 2.8 & 1,4 \\
\hline CARRIAGE Y ACCEL (G) & 0.01 & 1525 & $-13,89$ & 2.8 & 20 \\
\hline CARRIAGE Z ACCEL (G) & -0.72 & 274.51 & $-9,31$ & 20 & 7.7 \\
\hline CARRIAGE RES ACCEL (G) & 0.72 & 274.86 & 0.25 & 2.0 & 11.2 \\
\hline INTEGRATED ACCEL (FT/SEC) & 9.89 & 10.28 & -6.35 & 0.0 & 4.9 \\
\hline CARRIAGE X1 ACCEL (G) & -0.02 & 19.46 & -22.77 & 2.3 & 1.8 \\
\hline CARRIAGE Y1 ACCEL (G) & 0.03 & 1752 & -2204 & 1.8 & 3.3 \\
\hline CARRIAGE Z1 ACCEL (G) & -0.71 & 293.26 & -7.18 & 2.0 & 5.2 \\
\hline CARRIAGE RES1 ACCEL (G) & 0.71 & 293.31 & 0.24 & 20 & 39.4 \\
\hline CARRIAGE X2 ACCEL (G) & 0,02 & 18.10 & $-23,87$ & 2.9 & 1.9 \\
\hline CARRIAGE Y2 ACCEL (G) & 0,00 & 12.44 & -19.04 & 1.1 & 3.0 \\
\hline CARRIAGE Z2 ACCEL (G) & -075 & 292.90 & $-6,74$ & 2,3 & 72 \\
\hline CARRIAGE RES2 ACCEL (G) & 0,75 & 292.91 & 0,07 & 2,3 & 33,3 \\
\hline & & & & & \\
\hline & & & & & \\
\hline & & & & & \\
\hline & & & & & \\
\hline & & & & & \\
\hline & & & & & \\
\hline & & & & & \\
\hline & & & & & \\
\hline & & & & & \\
\hline & & & & & \\
\hline
\end{tabular}

Page 1 of 1

78 
201304 Test: 1091 Test Date: 130514 Subj: 3251 Cell: P

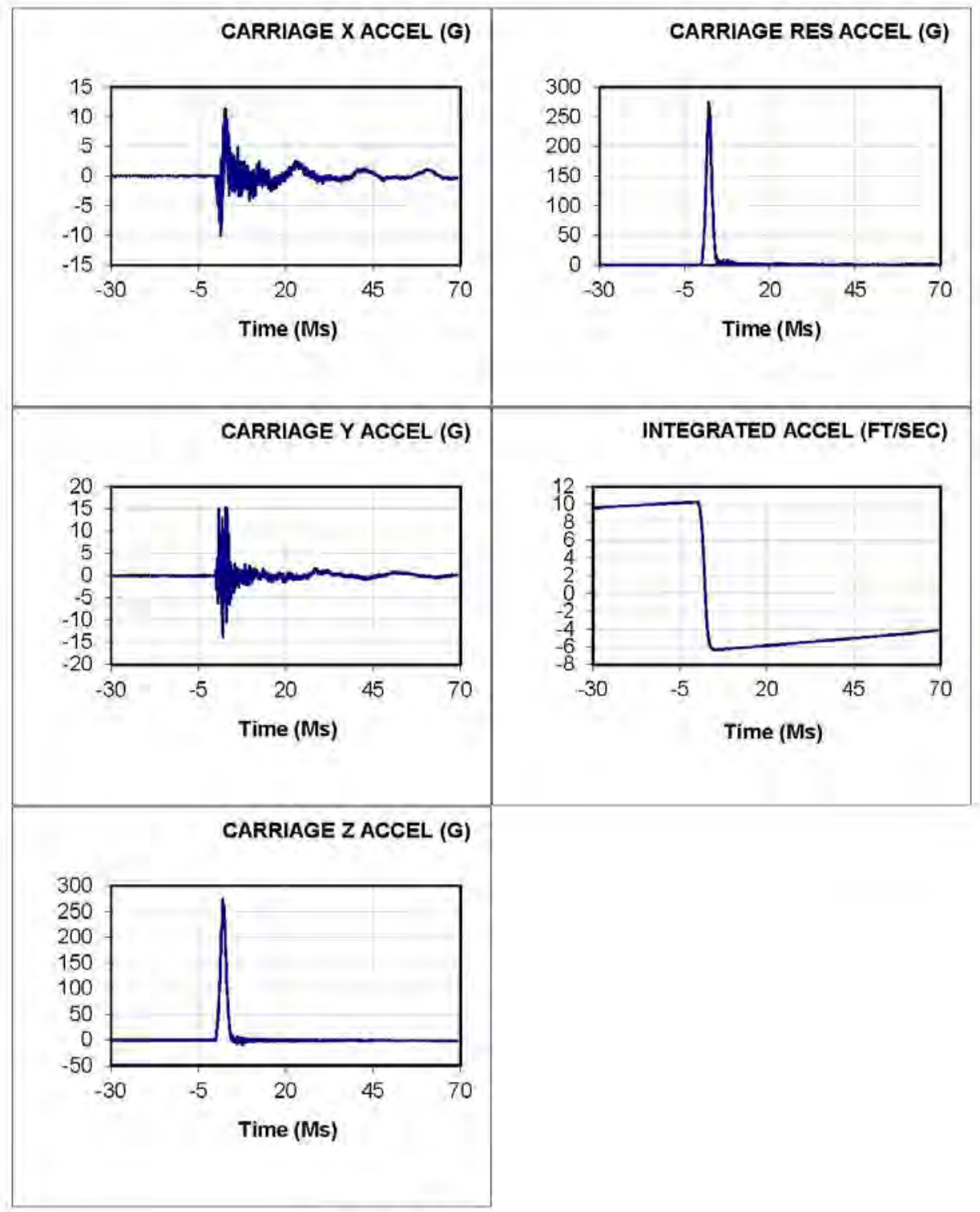

Page 1 of 3 
201304 Test: 1091 Test Date: 130514 Subj: 3251 Cell: P

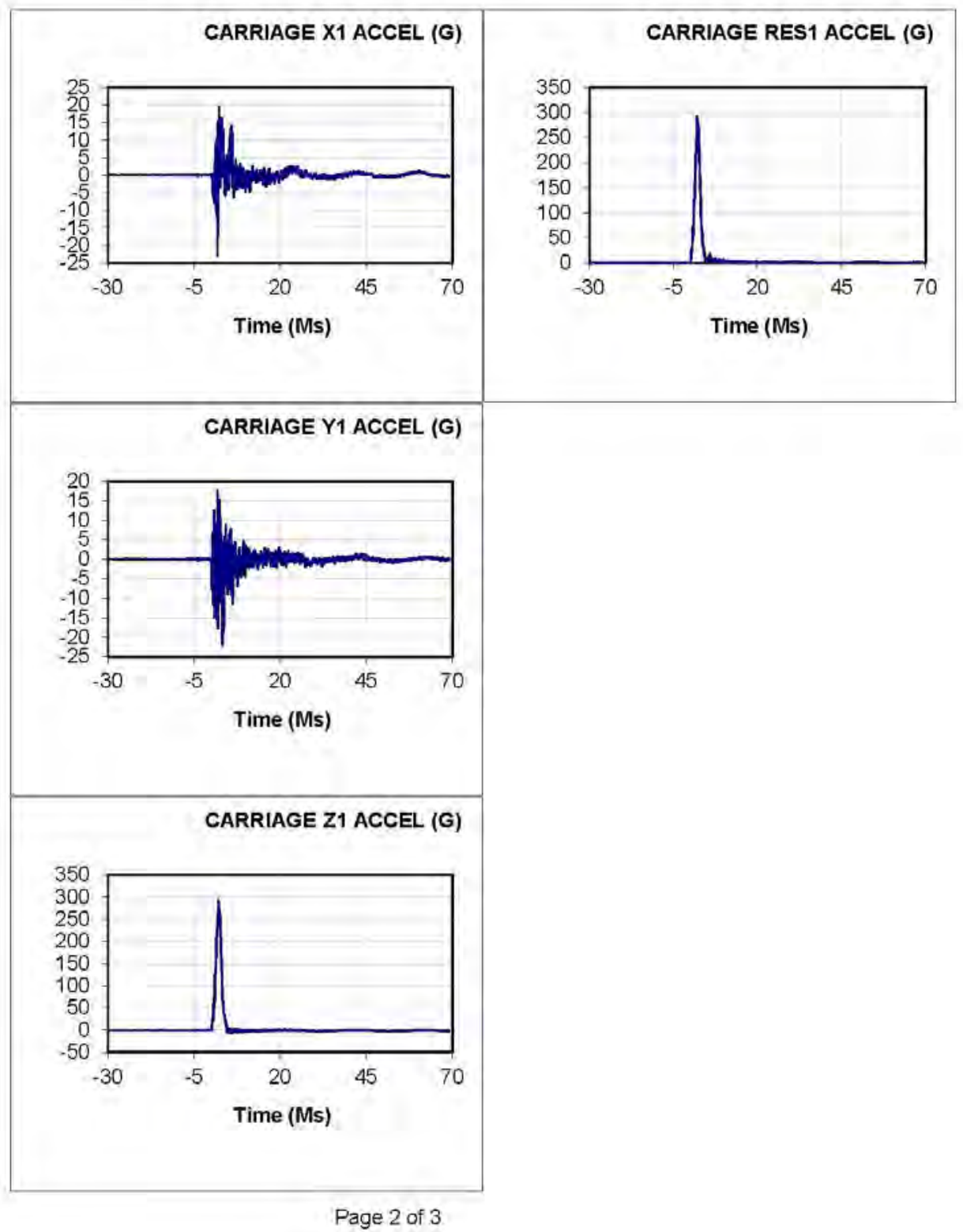


201304 Test: 1091 Test Date: 130514 Subj: 3251 Cell: P

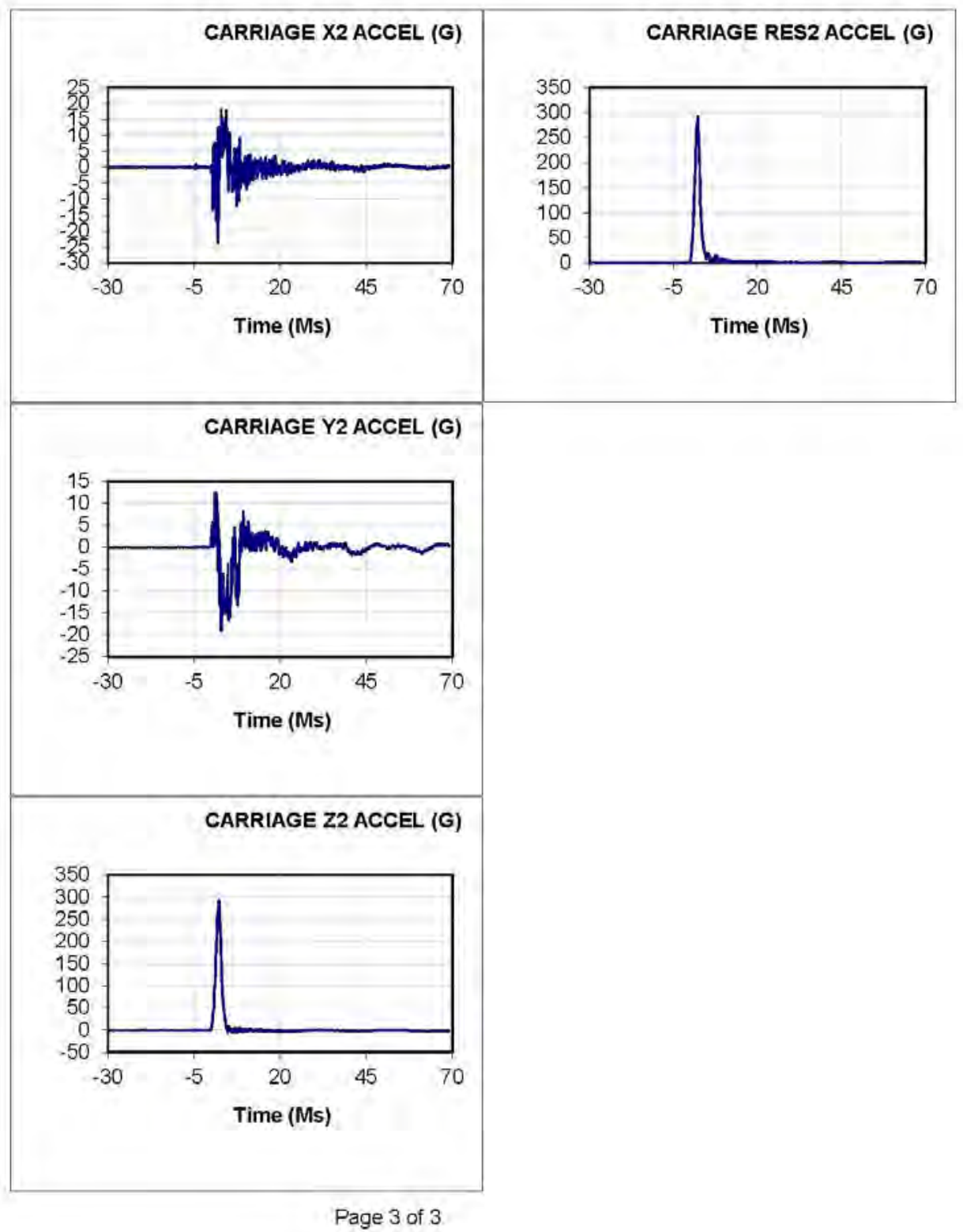




\section{APPENDIX F. VID CHARACTERIZATION WITH FELT PROGRAMMERS (THICKNESS VARIATION): TEST-BY-TEST SUMMARY}

- Test 1097: Cell Q, Test 1; Felt Density $20 \mathrm{~S} 1$ (0.25inch)/ Red IMPAC Programmer; Drop Height $=10$ inch, Peak G level $=92.16$, Integrated Velocity Change $=8.15 \mathrm{ft} / \mathrm{s}$, Time-toPeak Acceleration $=2.9 \mathrm{~ms}$, Time-to-Peak Velocity $=6.9 \mathrm{~ms}$.

Successful Test - All electronic data channels were present and continuous, data was successfully collected, desired test condition was achieved.

- Test 1098: Cell R, Test 1; Felt Density 20S1 (0.50inch)/ Red IMPAC Programmer; Drop Height $=10$ inch, Peak G level $=80.56$, Integrated Velocity Change $=8.36 \mathrm{ft} / \mathrm{s}$, Time-toPeak Acceleration $=3.2 \mathrm{~ms}$, Time-to-Peak Velocity $=8.1 \mathrm{~ms}$.

Successful Test - All electronic data channels were present and continuous, data was successfully collected, desired test condition was achieved. Third drop with the 0.50 inch thick 20S1 felt (flipped and reused because limited supply).

- Test 1099: Cell S, Test 1; Felt Density 20S1 (1.00inch)/ Red IMPAC Programmer; Drop Height $=10$ inch, Peak G level $=55.81$, Integrated Velocity Change $=8.41 \mathrm{ft} / \mathrm{s}$, Time-toPeak Acceleration $=4.5 \mathrm{~ms}$, Time-to-Peak Velocity $=11.6 \mathrm{~ms}$.

Successful Test - All electronic data channels were present and continuous, data was successfully collected, desired test condition was achieved.

- Test 1100: Cell T, Test 1; Felt Density 20S1 (2.00inch)/ Red IMPAC Programmer; Drop Height $=10$ inch, Peak G level $=41.4$, Integrated Velocity Change $=8.56 \mathrm{ft} / \mathrm{s}$, Time-toPeak Acceleration $=5.9 \mathrm{~ms}$, Time-to-Peak Velocity $=14.7 \mathrm{~ms}$.

Successful Test - All electronic data channels were present and continuous, data was successfully collected, desired test condition was achieved.

- Test 1101: Cell Q, Test 2; Felt Density $20 \mathrm{~S} 1$ (0.25inch)/ Red IMPAC Programmer; Drop Height $=10$ inch, Peak G level $=98.05$, Integrated Velocity Change $=8.29 \mathrm{ft} / \mathrm{s}$, Time-toPeak Acceleration $=2.9 \mathrm{~ms}$, Time-to-Peak Velocity $=6.6 \mathrm{~ms}$.

Successful Test - All electronic data channels were present and continuous, data was successfully collected, desired test condition was achieved.

- Test 1102: Cell R, Test 2; Felt Density $20 \mathrm{~S} 1$ (0.50inch)/ Red IMPAC Programmer; Drop Height $=10$ inch, Peak G level $=81.76$, Integrated Velocity Change $=8.32 \mathrm{ft} / \mathrm{s}$, Time-toPeak Acceleration $=3.5 \mathrm{~ms}$, Time-to-Peak Velocity $=8.1 \mathrm{~ms}$.

Successful Test - All electronic data channels were present and continuous, data was successfully collected, desired test condition was achieved. Fourth drop with the 0.50 inch thick 20S1 felt (twice each side for limited supply purposes). 
- Test 1103: Cell S, Test 2; Felt Density 20S1 (1.00inch)/ Red IMPAC Programmer; Drop Height $=10$ inch, Peak G level $=58.89$, Integrated Velocity Change $=8.56 \mathrm{ft} / \mathrm{s}$, Time-toPeak Acceleration $=4.4 \mathrm{~ms}$, Time-to-Peak Velocity $=11.3 \mathrm{~ms}$.

Successful Test - All electronic data channels were present and continuous, data was successfully collected, desired test condition was achieved.

- Test 1104: Cell T, Test 2; Felt Density 20S1 (2.00inch)/ Red IMPAC Programmer; Drop Height $=10$ inch, Peak G level $=41.92$, Integrated Velocity Change $=8.55 \mathrm{ft} / \mathrm{s}$, Time-toPeak Acceleration $=6.1 \mathrm{~ms}$, Time-to-Peak Velocity $=14.5 \mathrm{~ms}$.

Successful Test - All electronic data channels were present and continuous, data was successfully collected, desired test condition was achieved.

- Test 1105: Cell U, Test 1; Felt Density 20S1 (0.25inch)/ Red IMPAC Programmer; Drop Height $=40$ inch, Peak G level $=331$, Integrated Velocity Change $=16.46 \mathrm{ft} / \mathrm{s}$, Time-toPeak Acceleration $=1.9 \mathrm{~ms}$, Time-to-Peak Velocity $=4.7 \mathrm{~ms}$.

Successful Test - All electronic data channels were present and continuous, data was successfully collected, desired test condition was achieved.

- Test 1106: Cell V, Test 1; Felt Density 20S1 (0.50inch)/ Red IMPAC Programmer; Drop Height $=40$ inch, Peak G level $=283.84$, Integrated Velocity Change $=16.53 \mathrm{ft} / \mathrm{s}$, Timeto-Peak Acceleration $=2.3 \mathrm{~ms}$, Time-to-Peak Velocity $=5.2 \mathrm{~ms}$.

Successful Test - All electronic data channels were present and continuous, data was successfully collected, desired test condition was achieved. Fifth drop with the 0.50 inch thick 20S1 felt (re-flipped for limited supply purposes).

- Test 1107: Cell W, Test 1; Felt Density 20S1 (1.00inch)/ Red IMPAC Programmer; Drop Height $=40$ inch, Peak G level $=189.8$, Integrated Velocity Change $=16.54 \mathrm{ft} / \mathrm{s}$, Time-to-Peak Acceleration $=3.5 \mathrm{~ms}$, Time-to-Peak Velocity $=8.5 \mathrm{~ms}$.

Successful Test - All electronic data channels were present and continuous, data was successfully collected, desired test condition was achieved.

- Test 1108: Cell X, Test 1; Felt Density 20S1 (2.00inch)/ Red IMPAC Programmer; Drop Height $=40$ inch, Peak G level $=112.85$, Integrated Velocity Change $=16.34 \mathrm{ft} / \mathrm{s}$, Timeto-Peak Acceleration $=4.8 \mathrm{~ms}$, Time-to-Peak Velocity $=11.4 \mathrm{~ms}$.

Successful Test - All electronic data channels were present and continuous, data was successfully collected, desired test condition was achieved.

- Test 1109: Cell U, Test 2; Felt Density 20S1 (0.25inch)/ Red IMPAC Programmer; Drop Height $=40$ inch, Peak G level $=335.5$, Integrated Velocity Change $=16.37 \mathrm{ft} / \mathrm{s}$, Timeto-Peak Acceleration $=1.9 \mathrm{~ms}$, Time-to-Peak Velocity $=4.6 \mathrm{~ms}$.

Successful Test - All electronic data channels were present and continuous, data was successfully collected, desired test condition was achieved. 
- Test 1110: Cell V, Test 2; Felt Density 20S1 (0.50inch)/ Red IMPAC Programmer; Drop Height $=40$ inch, Peak G level $=276.39$, Integrated Velocity Change $=16.28 \mathrm{ft} / \mathrm{s}$, Timeto-Peak Acceleration $=2.3 \mathrm{~ms}$, Time-to-Peak Velocity $=6.1 \mathrm{~ms}$.

Successful Test - All electronic data channels were present and continuous, data was successfully collected, desired test condition was achieved. Sixth drop with the 0.50 inch thick 20S1 felt (three times each side for limited supply purposes).

- Test 1111: Cell W, Test 2; Felt Density 20S1 (1.00inch)/ Red IMPAC Programmer; Drop Height $=40$ inch, Peak G level $=188.83$, Integrated Velocity Change $=16.28 \mathrm{ft} / \mathrm{s}$, Time-to-Peak Acceleration $=3.3 \mathrm{~ms}$, Time-to-Peak Velocity $=7.9 \mathrm{~ms}$.

Successful Test - All electronic data channels were present and continuous, data was successfully collected, desired test condition was achieved.

- Test 1112: Cell X, Test 2; Felt Density 20S1 (2.00inch)/ Red IMPAC Programmer; Drop Height $=40$ inch, Peak G level $=118.43$, Integrated Velocity Change $=16.57 \mathrm{ft} / \mathrm{s}$, Timeto-Peak Acceleration $=4.6 \mathrm{~ms}$, Time-to-Peak Velocity $=11.5 \mathrm{~ms}$.

Successful Test - All electronic data channels were present and continuous, data was successfully collected, desired test condition was achieved. 


\section{APPENDIX G: SAMPLE DATA SHEETS - FELT PROGRAMMERS (THICKNESS VARIATION)}

Test 1105: Cell U, Felt Thickness: 0.25 inch, Felt Density 20S1; Drop Height $=40$ inch, Peak G level $=331$, Integrated Velocity Change $=16.46 \mathrm{ft} / \mathrm{s}$, Time-to-Peak Acceleration $=$ $1.9 \mathrm{~ms}$, Time-to-Peak Velocity $=4.7 \mathrm{~ms}$.

Test 1106: Cell V, Felt Thickness: 0.50 inch, Felt Density 20S1; Drop Height $=40$ inch, Peak G level $=283.84$, Integrated Velocity Change $=16.53 \mathrm{ft} / \mathrm{s}$, Time-to-Peak Acceleration $=$ $2.3 \mathrm{~ms}$, Time-to-Peak Velocity $=5.2 \mathrm{~ms}$.

Test 1107: Cell W, Felt Thickness: 1.00 inch, Felt Density 20S1; Drop Height $=40$ inch, Peak G level $=189.8$, Integrated Velocity Change $=16.54 \mathrm{ft} / \mathrm{s}$, Time-to-Peak Acceleration $=$ $3.5 \mathrm{~ms}$, Time-to-Peak Velocity $=8.5 \mathrm{~ms}$.

Test 1108: Cell X, Felt Thickness: 2.00 inch, Felt Density 20S1; Drop Height $=40$ inch, Peak G level $=112.85$, Integrated Velocity Change $=16.34 \mathrm{ft} / \mathrm{s}$, Time-to-Peak Acceleration $=$ $4.8 \mathrm{~ms}$, Time-to-Peak Velocity $=11.4 \mathrm{~ms}$. 
201304 Test: 1105 Test Date; 130515 Subj: 2051525 Wt . 0

Nom G: 300 . Cell: U

\begin{tabular}{|c|c|c|c|c|c|}
\hline Data ID & $\begin{array}{l}\text { Immediate } \\
\text { Preimpact }\end{array}$ & $\begin{array}{c}\text { Maximum } \\
\text { Value }\end{array}$ & $\begin{array}{c}\text { Minimum } \\
\text { Value }\end{array}$ & $\begin{array}{l}\text { Time of } \\
\text { Maximum }\end{array}$ & $\begin{array}{l}\text { Time of } \\
\text { Minumum }\end{array}$ \\
\hline $\begin{array}{l}\text { Reference Mark Time (Ms) } \\
\text { Drop Height (In) } \\
\text { Impact Rise Time (Ms) } \\
\text { Impact Duration (Ms) } \\
\text { Velocity Change (Ft/Sec) }\end{array}$ & & 4000 & & $\begin{array}{l}1.9 \\
4.0\end{array}$ & \\
\hline CARRIAGE X ACCEL (G) & -0.01 & 17.12 & $-8,11$ & 2.3 & 1.4 \\
\hline CARRIAGE Y ACCEL (G) & 0.01 & 4.62 & -1224 & 31 & 19 \\
\hline CARRIAGE Z ACCEL (G) & $=0.72$ & 33100 & -8.26 & 1.9 & 94 \\
\hline CARRIAGE RES ACCEL (G) & 0.72 & 331.24 & 0.28 & 1.9 & 26.5 \\
\hline INTEGRATED ACCEL (FT/SEC) & 10.10 & 10.48 & -5.98 & 0.0 & 4.7 \\
\hline CARRIAGE X1 ACCEL (G) & -0.01 & 15.97 & -19.17 & 5.8 & 5.3 \\
\hline CARRIAGE Y1 ACCEL (G) & 0.02 & 20.34 & $-21,58$ & 22 & 3.2 \\
\hline CARRIAGE Z1 ACCEL (G) & -0.71 & 352.86 & -15.47 & 20 & 45 \\
\hline CARRIAGE RES1 ACCEL (G) & 0.72 & 352.92 & 0.12 & 2.0 & 39.8 \\
\hline CARRIAGE X2 ACCEL (G) & 0.02 & 22.55 & -26.62 & 4.9 & 3.1 \\
\hline CARRIAGE Y2 ACCEL (G) & 0.00 & 15.41 & -17.55 & 1.3 & 2.7 \\
\hline CARRIAGE Z2 ACCEL (G) & -076 & 34657 & $-13,68$ & 1.8 & 43 \\
\hline CARRIAGE RES2 ACCEL (G) & 0,76 & 34663 & 0,17 & 1.8 & 48,7 \\
\hline & & & & & \\
\hline & & & & & \\
\hline & & & & & \\
\hline & & & & & \\
\hline & & & & & \\
\hline & & & & & \\
\hline & & & & & \\
\hline & & & & & \\
\hline & & & & & \\
\hline & & & & & \\
\hline
\end{tabular}

Page 1 of 1

87 
201304 Test: 1105 Test Date: 130515 Subj; 2051 S25 Cell. U

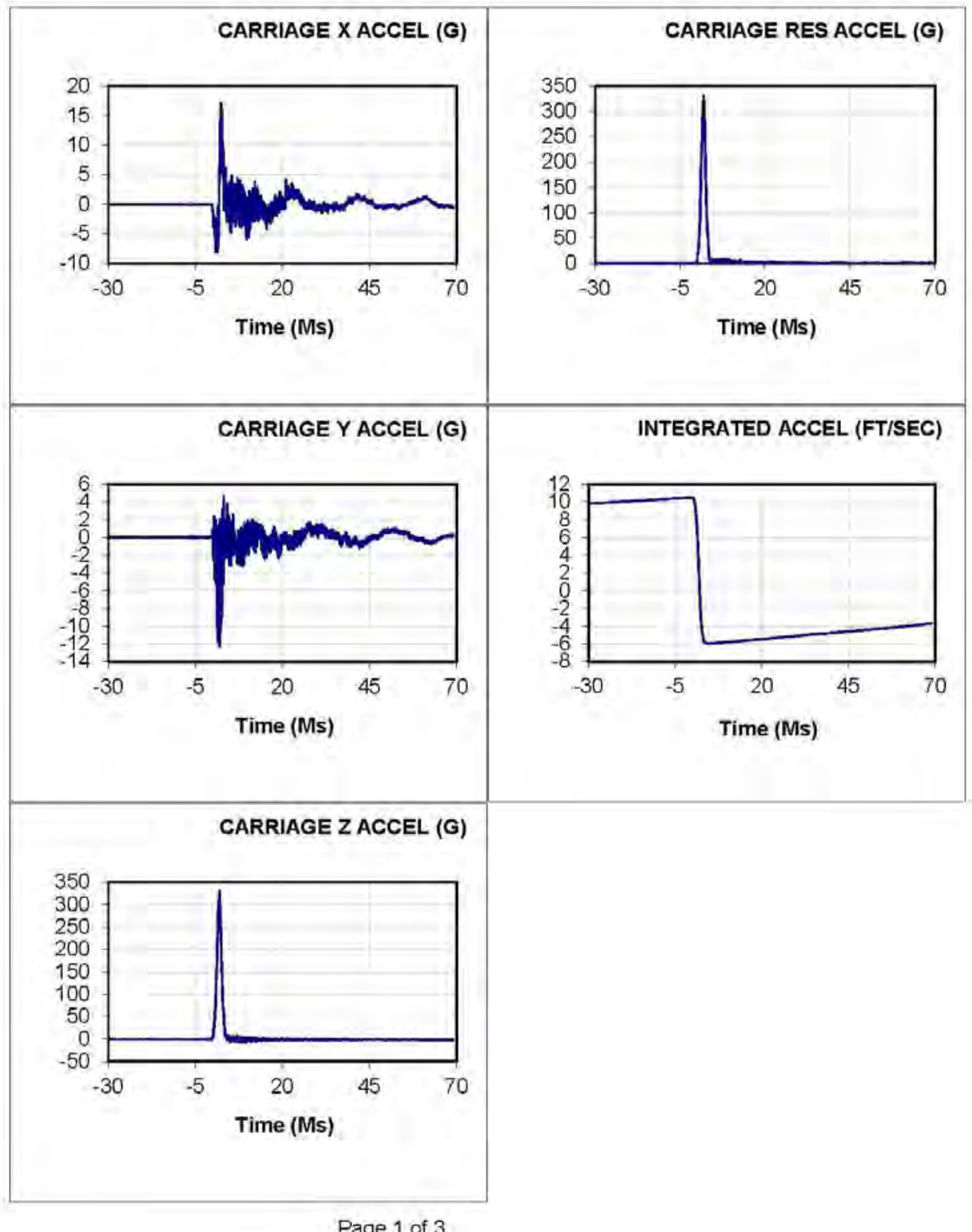

Page 1 of 3 
201304 Test: 1105 Test Date: 130515 Subj: $2051 \$ 25$ Cell. U

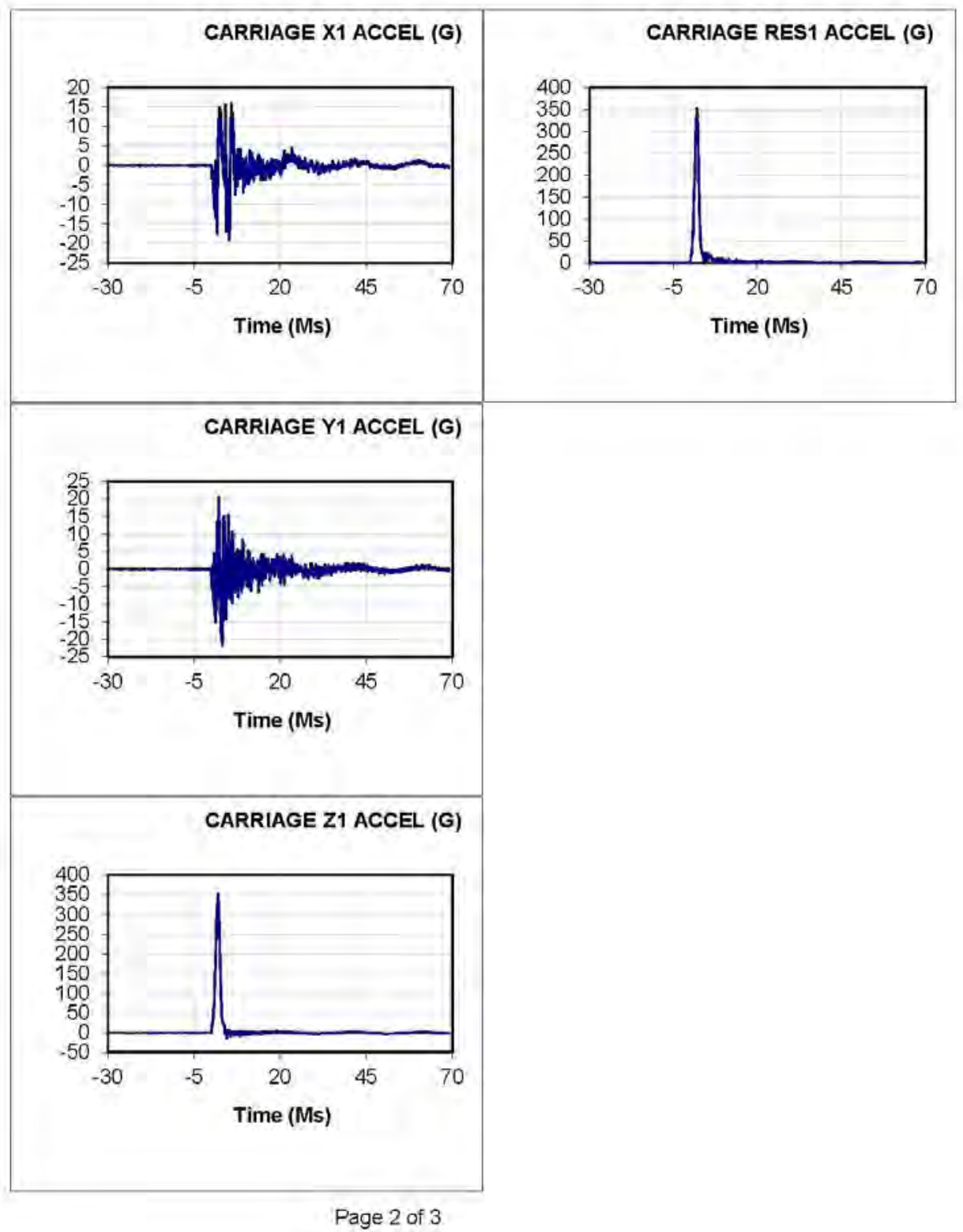


201304 Test: 1105 Test Date: 130515 Subj: 2051 S25 Cell. U

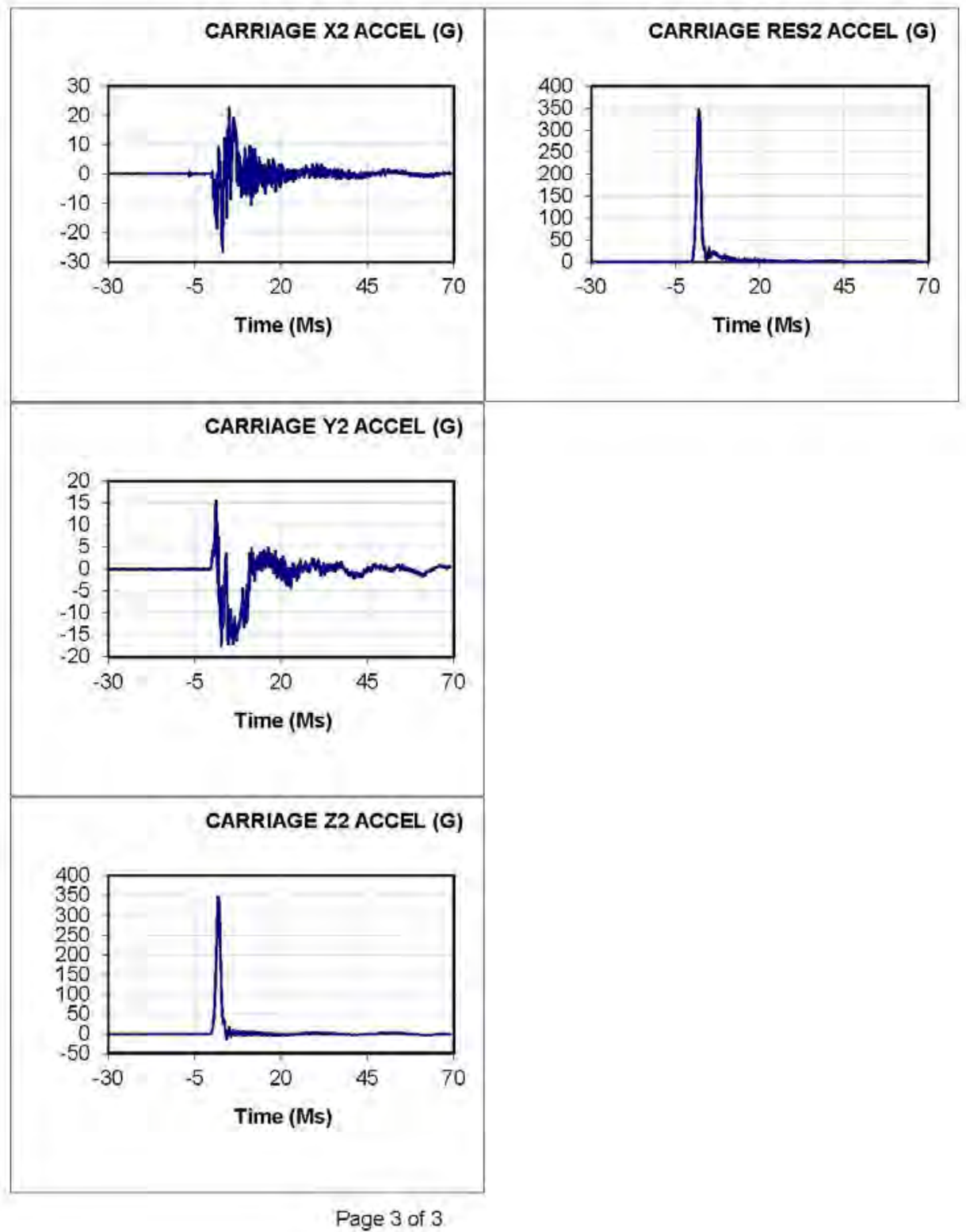


201304 Test: 1106 Test Date: 130515 Subj: 2051550 Wt 0

Nom G: 300.0 Cell: V

\begin{tabular}{|c|c|c|c|c|c|}
\hline Data ID & $\begin{array}{l}\text { Immediate } \\
\text { Preimpact }\end{array}$ & $\begin{array}{l}\text { Maximum } \\
\text { Value }\end{array}$ & $\begin{array}{l}\text { Minimum } \\
\text { Value }\end{array}$ & $\begin{array}{c}\text { Time of } \\
\text { Maximum }\end{array}$ & $\begin{array}{l}\text { Time of } \\
\text { Minimum }\end{array}$ \\
\hline $\begin{array}{l}\text { Reference Mark Time (Ms) } \\
\text { Drop Height (In) } \\
\text { Impact Rise Time (Ms) } \\
\text { Impact Duration (Ms) } \\
\text { Velocity Change (Ft/Sec) }\end{array}$ & & 4000 & & $\begin{array}{l}2,3 \\
5,3\end{array}$ & \\
\hline CARRIAGE X ACCEL (G) & -0.01 & 25.61 & -103.69 & 3.8 & 5.8 \\
\hline CARRIAGE Y ACCEL (G) & 0.01 & 165 & -10.17 & 49 & 20 \\
\hline CARRIAGE Z ACCEL (G) & -0.67 & 28384 & -7.42 & 23 & 81 \\
\hline CARRIAGE RES ACCEL (G) & 0,67 & 283.89 & 0.45 & 2.3 & 11.8 \\
\hline INTEGRATED ACCEL (FT/SEC) & 9.64 & 10.00 & -6.53 & 0.0 & 5.2 \\
\hline CARRIAGE X1 ACCEL (G) & -0.01 & 16.70 & -8.70 & 4.8 & 1.1 \\
\hline CARRIAGE Y1 ACCEL (G) & 0.02 & 1267 & -1331 & 4.1 & 3.7 \\
\hline CARRIAGE Z1 ACCEL (G) & -0.73 & 293.63 & -8.80 & 24 & 63 \\
\hline CARRIAGE RES1 ACCEL (G) & 0.73 & 293.63 & 0.15 & 2.4 & 38.3 \\
\hline CARRIAGE X2 ACCEL (G) & 0.03 & 7.47 & -15.41 & 5,5 & 3.2 \\
\hline CARRIAGE Y2 ACCEL (G) & 0.00 & 8.96 & -12.87 & 7.2 & 6.2 \\
\hline CARRIAGE Z2 ACCEL (G) & -079 & 30543 & $-5,26$ & 22 & 4.7 \\
\hline CARRIAGE RES2 ACCEL (G) & 0,79 & 305,50 & 0,21 & 22 & 33.2 \\
\hline & & & & & \\
\hline & & & & & \\
\hline & & & & & \\
\hline & & & & & \\
\hline & & & & & \\
\hline & & & & & \\
\hline & & & & & \\
\hline & & & & & \\
\hline & & & & & \\
\hline & & & & & \\
\hline
\end{tabular}

Page 1 of 1 
201304 Test: 1106 Test Date: 130515 Subj: 2051550 Cell: V

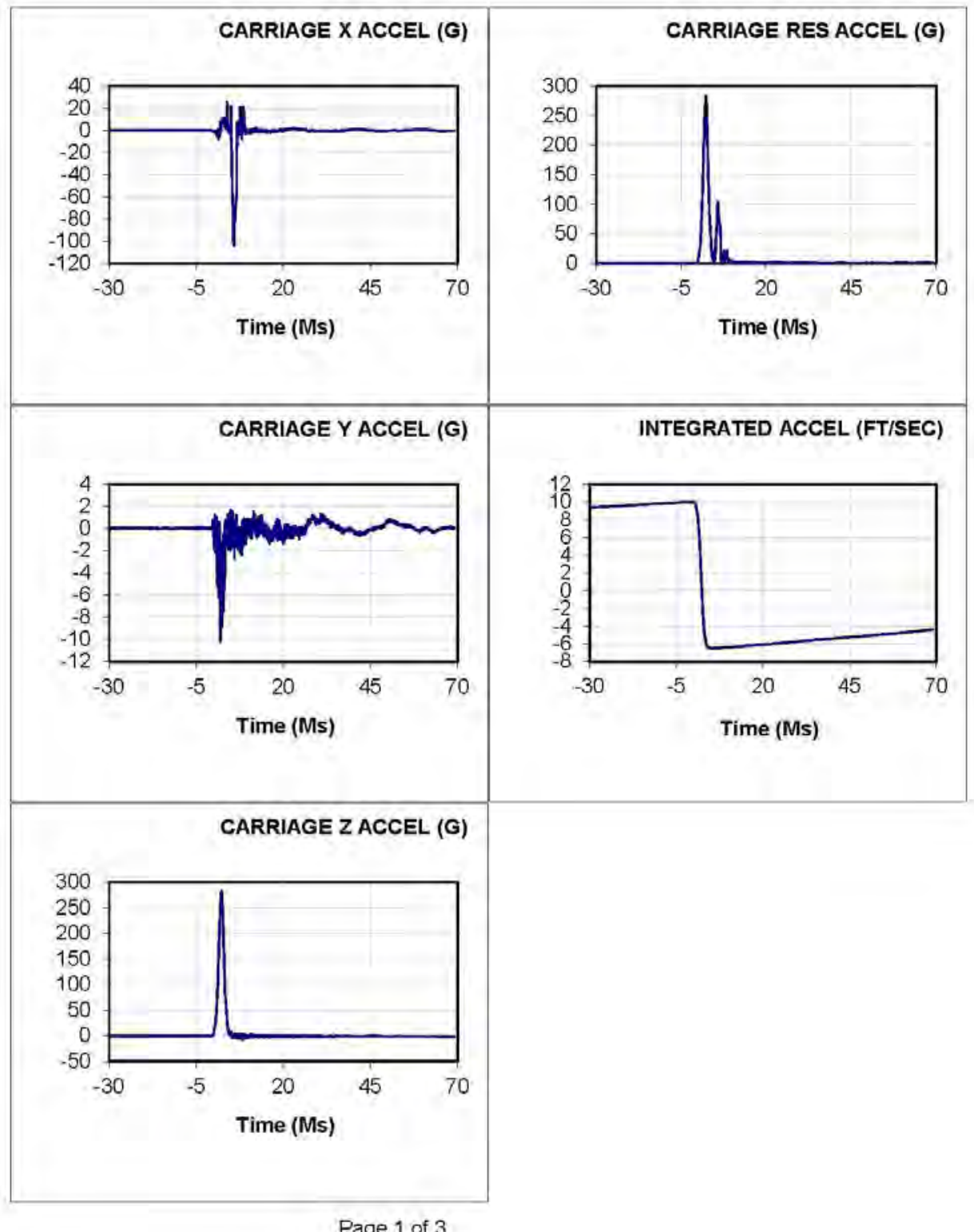

Page 1 of 3 
201304 Test: 1106 Test Date: 130515 Subj: 2051550 Cell: V

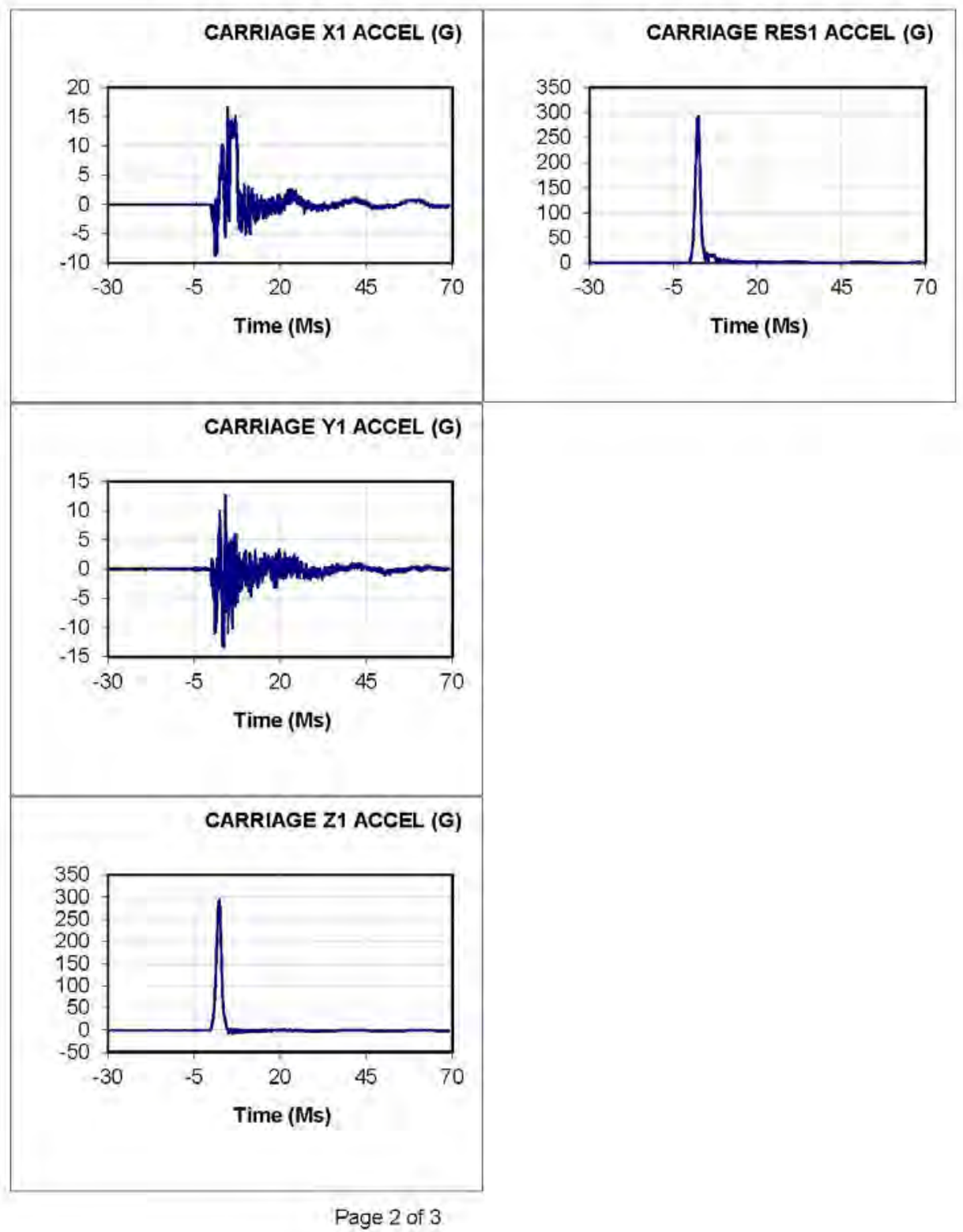


201304 Test: 1106 Test Date: 130515 Subj: 2051550 Cell: V

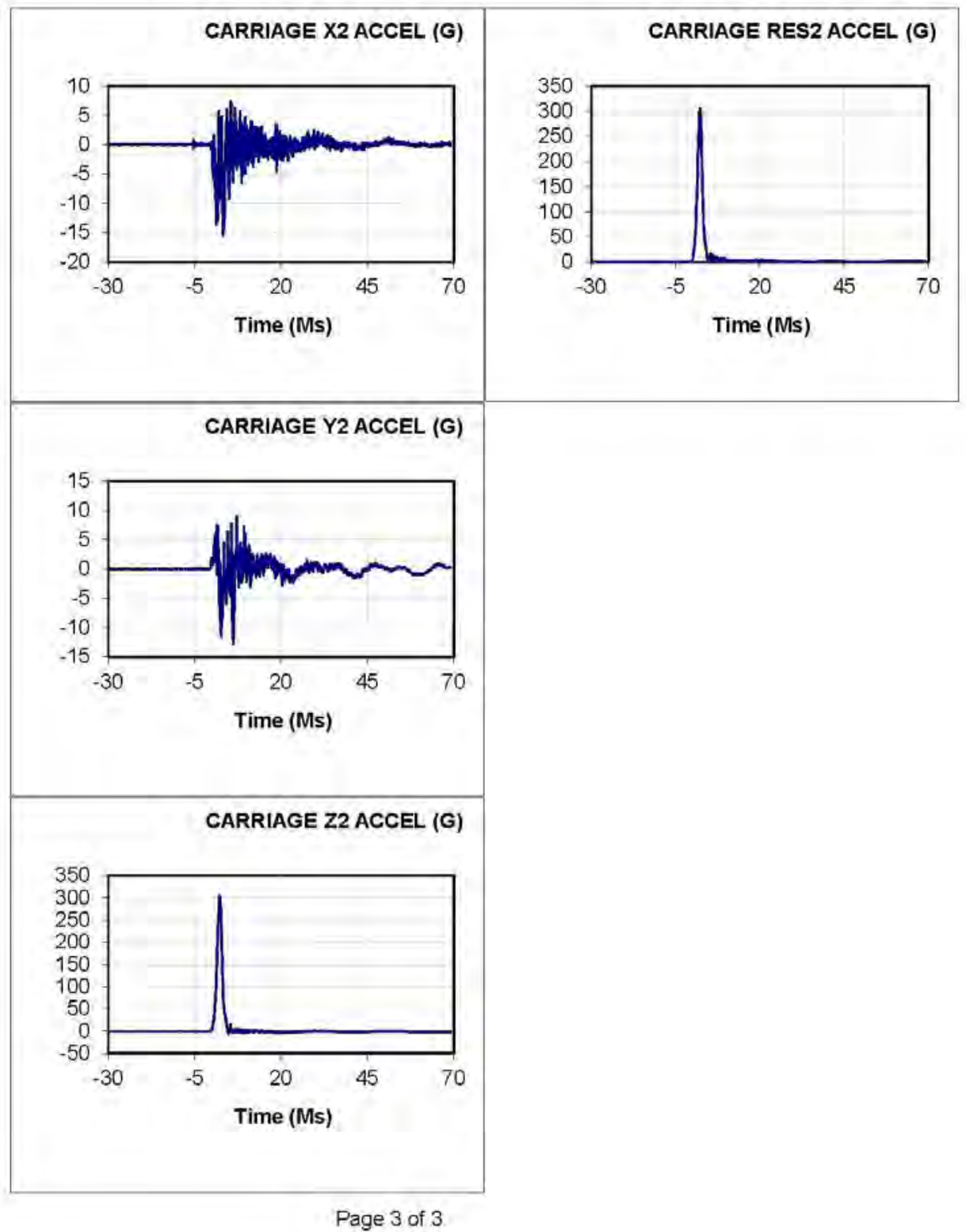


201304 Test: 1107 Test Date: 130515 Subj: 20515100 Wt: 0

Nom G: 280.0 Cell: W

\begin{tabular}{|c|c|c|c|c|c|}
\hline Data ID & $\begin{array}{l}\text { Immediate } \\
\text { Preimpact }\end{array}$ & $\begin{array}{c}\text { Maximum } \\
\text { Value }\end{array}$ & $\begin{array}{c}\text { Minimum } \\
\text { Value }\end{array}$ & $\begin{array}{l}\text { Time of } \\
\text { Maximum }\end{array}$ & $\begin{array}{l}\text { Time of } \\
\text { Minimum }\end{array}$ \\
\hline $\begin{array}{l}\text { Reference Mark Time (Ms) } \\
\text { Drop Height (In) } \\
\text { Impact Rise Time (Ms) } \\
\text { Impact Duration (Ms) } \\
\text { Velocity Change (Ft/Sec) }\end{array}$ & & 4000 & & $\begin{array}{r}0.0 \\
\\
3.5 \\
7.5\end{array}$ & \\
\hline CARRIAGE X ACCEL (G) & -0.02 & 98.62 & -116.09 & 2.0 & 6.9 \\
\hline CARRIAGE Y ACCEL (G) & 0.01 & 1.80 & -5.54 & 6.7 & 3.0 \\
\hline CARRIAGEZ ACCEL (G) & $=0.69$ & 18980 & -485 & 3.5 & 8.9 \\
\hline CARRIAGE RES ACCEL (G) & 0.69 & 190.01 & 0.23 & 3.3 & 15.7 \\
\hline INTEGRATED ACCEL (FT/SEC) & 9.69 & 10.03 & -6.51 & 0.0 & 8.5 \\
\hline CARRIAGE X1 ACCEL (G) & -0.01 & 4.52 & -3.23 & 4.1 & 1.1 \\
\hline CARRIAGE Y1 ACCEL (G) & 0.02 & 277 & -6.83 & 3,5 & 4.6 \\
\hline CARRIAGE Z1 ACCEL (G) & -0.76 & 200.51 & -454 & 33 & 8.7 \\
\hline CARRIAGE RES1 ACCEL (G) & 0.76 & 200.51 & 0.28 & 3.3 & 40.3 \\
\hline CARRIAGE X2 ACCEL (G) & 0.02 & 3.24 & $-8,43$ & 6.6 & 2.8 \\
\hline CARRIAGE Y2 ACCEL (G) & 0,00 & 227 & -3.17 & 1.9 & 3.3 \\
\hline CARRIAGE Z2 ACCEL (G) & $=0.75$ & 20010 & -405 & 3,3 & 198 \\
\hline CARRIAGE RES2 ACCEL (G) & 0,75 & 20023 & 0,08 & 3,3 & 49.2 \\
\hline & & & & & \\
\hline & & & & & \\
\hline & & & & & \\
\hline & & & & & \\
\hline & & & & & \\
\hline & & & & & \\
\hline & & & & & \\
\hline & & & & & \\
\hline & & & & & \\
\hline & & & & & \\
\hline
\end{tabular}

Page 1 of 1

95 
201304 Test: 1107 Test Date: 130515 Subj: 2051 S100 Cell. W

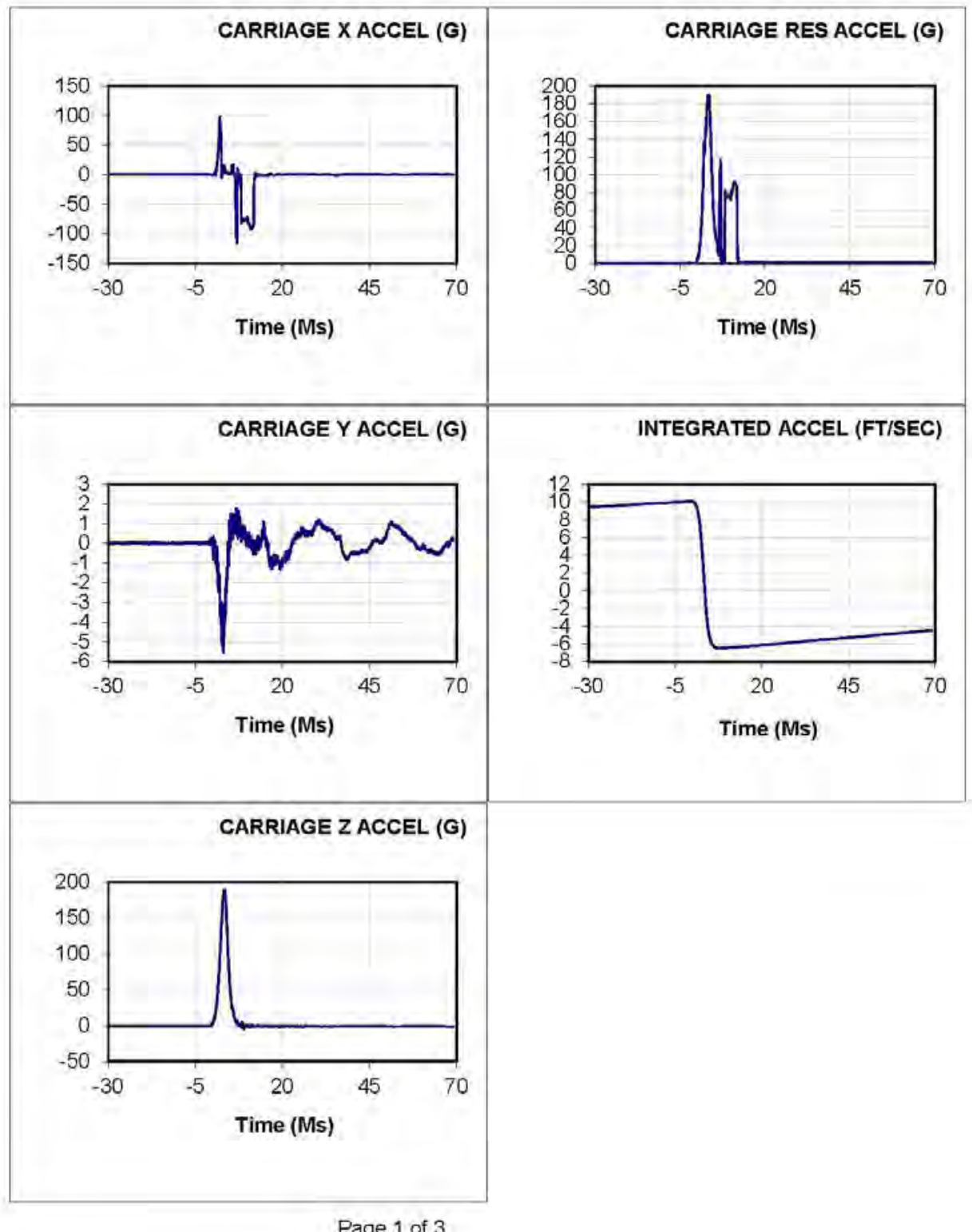

Page 1 of 3 
201304 Test: 1107 Test Date: 130515 Subj: 2051 S100 Cell. W

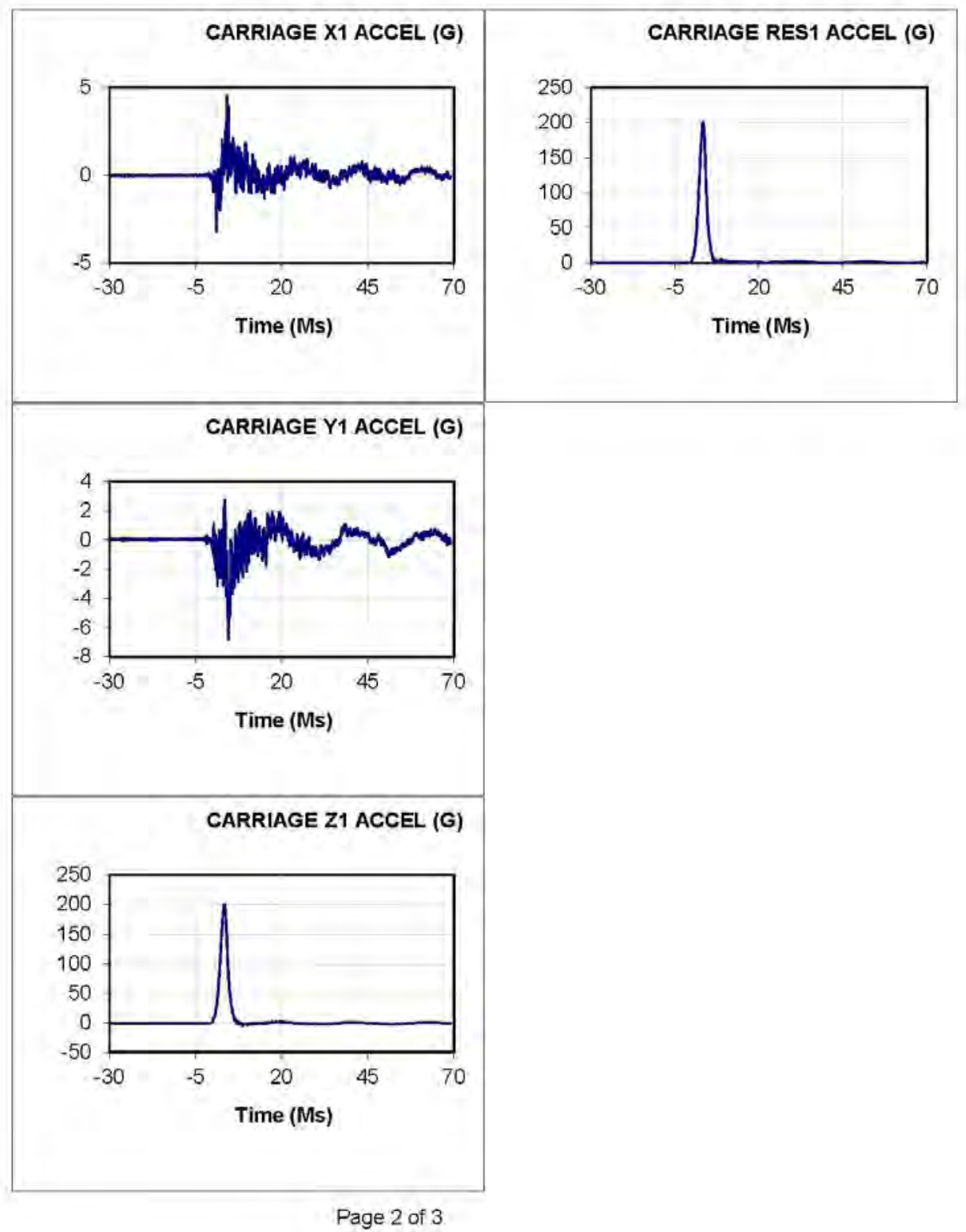


201304 Test: 1107 Test Date: 130515 Subj: 2051 S100 Cell. W

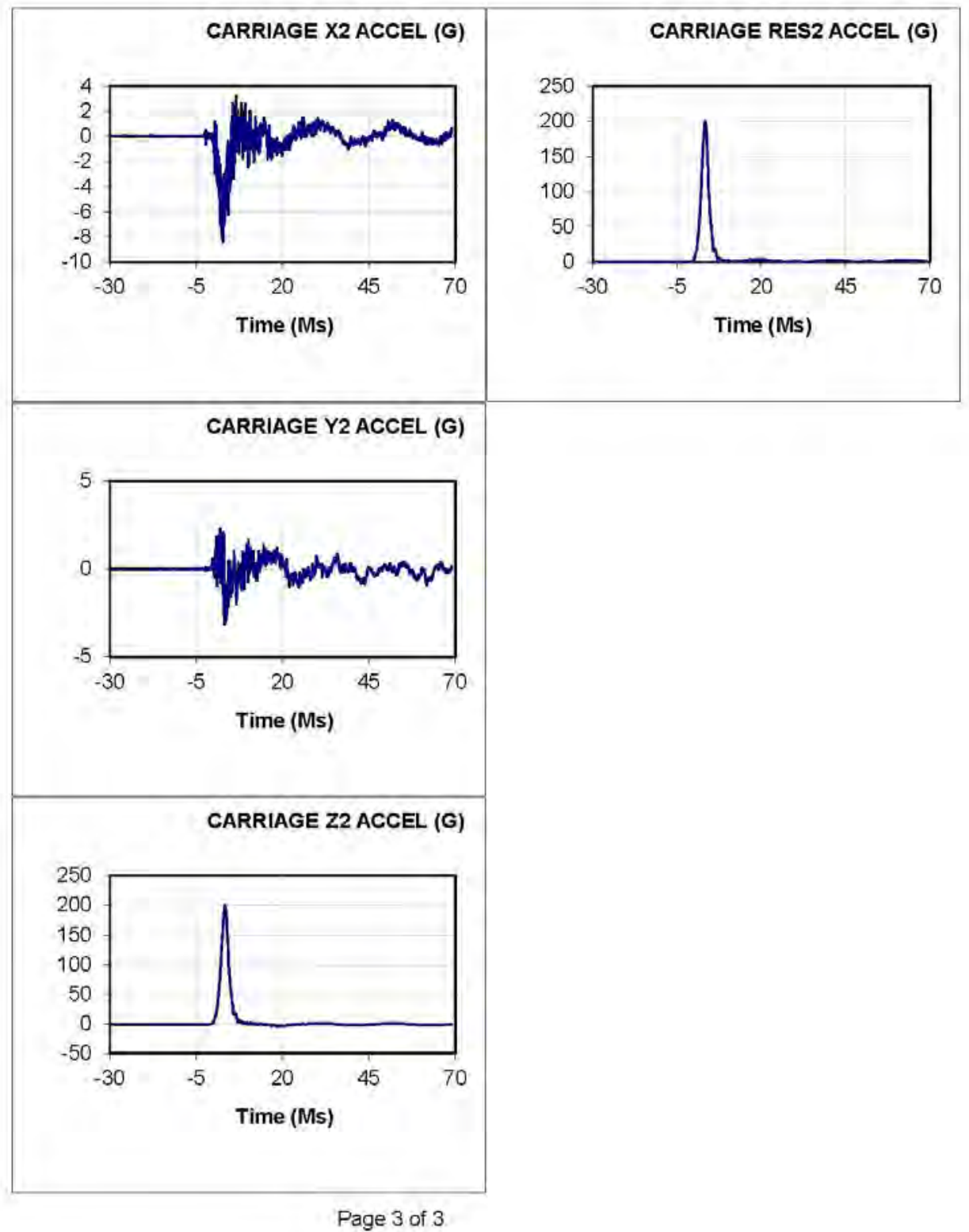


201304 Test: 1108 Test Date: 130515 Subj: 20515200 Wt: 0

Nom G: 1000 Cell: $X$

\begin{tabular}{|c|c|c|c|c|c|}
\hline $\begin{array}{r}\text { Data ID } \\
\end{array}$ & \begin{tabular}{l|} 
Immediate \\
Preimpact
\end{tabular} & $\begin{array}{c}\text { Maximum } \\
\text { Value }\end{array}$ & $\begin{array}{l}\text { Minimum } \\
\text { Value }\end{array}$ & $\begin{array}{l}\text { Time of } \\
\text { Maximum }\end{array}$ & $\begin{array}{l}\text { Time of } \\
\text { Minimum }\end{array}$ \\
\hline $\begin{array}{l}\text { Reference Mark Time (Ms) } \\
\text { Drop Height (In) } \\
\text { Impact Rise Time (Ms) } \\
\text { Impact Duration (Ms) } \\
\text { Velocity Change (Ft/Sec) }\end{array}$ & & 4000 & & $\begin{array}{r}0.2 \\
4.8 \\
11.1\end{array}$ & \\
\hline CARRIAGE X ACCEL (G) & .0 .02 & 80.23 & $-167,68$ & 2.2 & 9.9 \\
\hline CARRIAGE Y ACCEL (G) & 0.00 & 2.22 & -235 & 88 & 42 \\
\hline CARRIAGEZ ACCEL (G) & -0.69 & 112.85 & -2.05 & 48 & 181 \\
\hline CARRIAGE RES ACCEL (G) & 0.70 & 167.73 & 0,42 & 9.9 & 15.3 \\
\hline INTEGRATED ACCEL (FT/SEC) & 9.32 & 9.64 & -6.70 & 0.0 & 11.4 \\
\hline CARRIAGE X1 ACCEL (G) & -0.01 & 4.14 & -2.63 & 5.8 & 19.1 \\
\hline CARRIAGE Y1 ACCEL (G) & 0.02 & 223 & -532 & 20.0 & 6.8 \\
\hline CARRIAGE Z1 ACCEL (G) & -0.76 & 115.17 & -399 & 4.9 & 53.4 \\
\hline CARRIAGE RES1 ACCEL (G) & 0.76 & 11520 & 0.27 & 4.9 & 23.7 \\
\hline CARRIAGE X2 ACCEL (G) & 0.02 & 3.85 & -7.19 & 7.6 & 5.7 \\
\hline CARRIAGE Y2 ACCEL (G) & 0.00 & 2.67 & -3.36 & 3.7 & 7.9 \\
\hline CARRIAGE Z2 ACCEL (G) & -0.74 & 11947 & -479 & 49 & 19,6 \\
\hline CARRIAGE RES2 ACCEL (G) & 0,74 & 119,49 & 0,10 & 49 & 30,5 \\
\hline & & & & & \\
\hline & & & & & \\
\hline & & & & & \\
\hline & & & & & \\
\hline & & & & & \\
\hline & & & & & \\
\hline & & & & & \\
\hline & & & & & \\
\hline & & & & & \\
\hline & & & & & \\
\hline
\end{tabular}

Page 1 of 1

99 
201304 Test: 1108 Test Date: 130515 Subj: 2051 S200 Cell: $X$

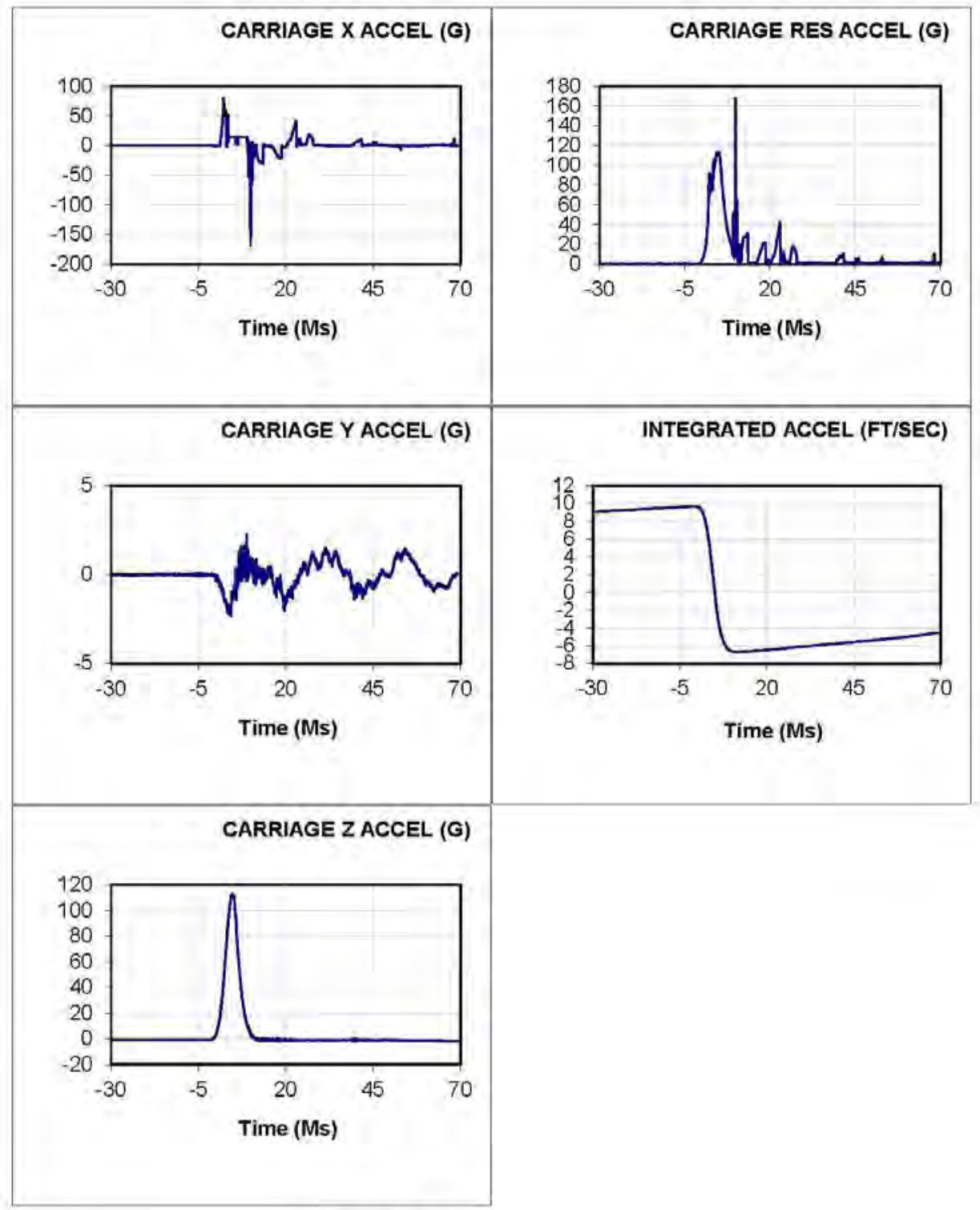

Page 1 of 3

100 
201304 Test: 1108 Test Date: 130515 Subj: 2051 S200 Cell: $X$

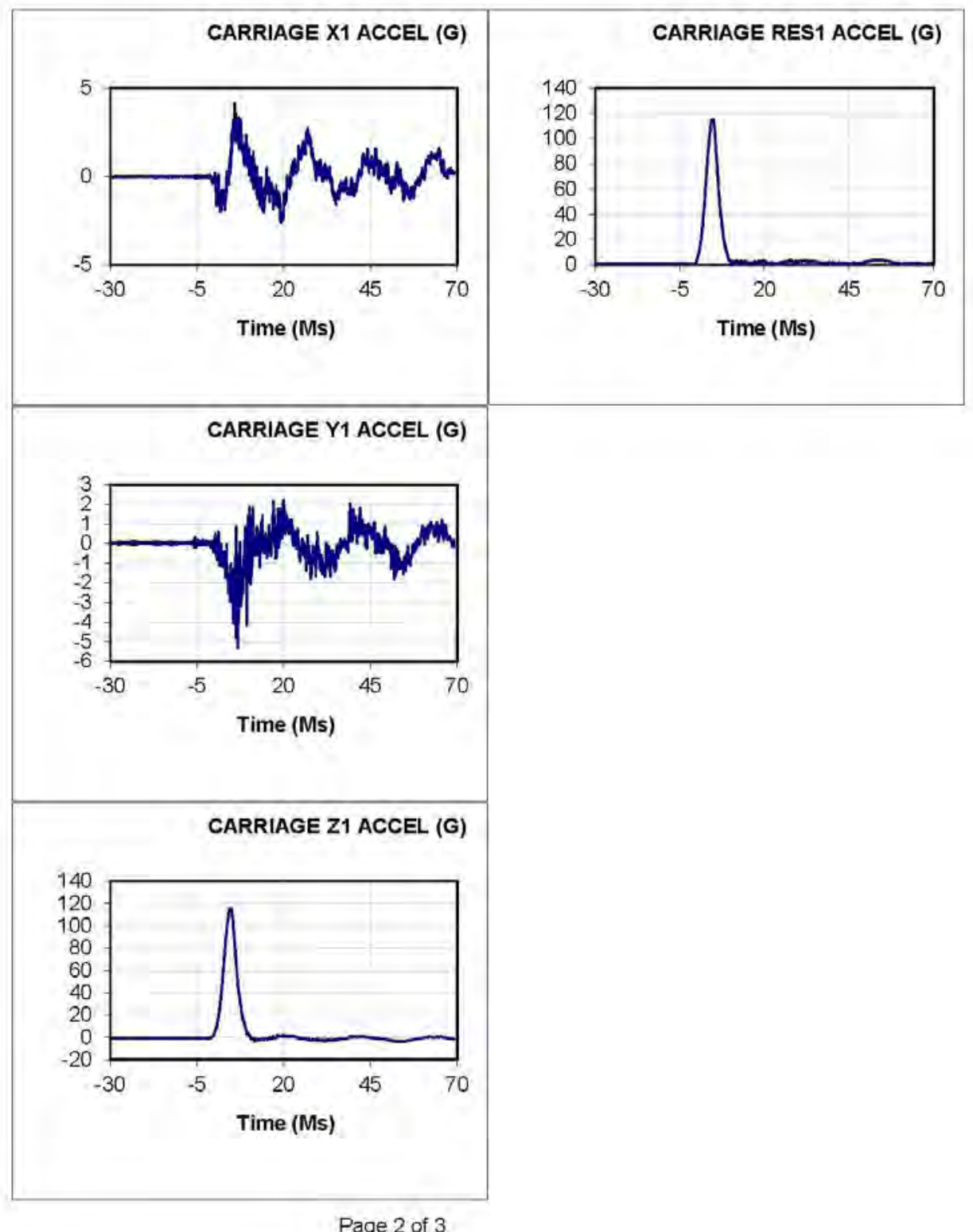

Page 2 of 3 
201304 Test: 1108 Test Date: 130515 Subj: 2051 S200 Cell: $X$

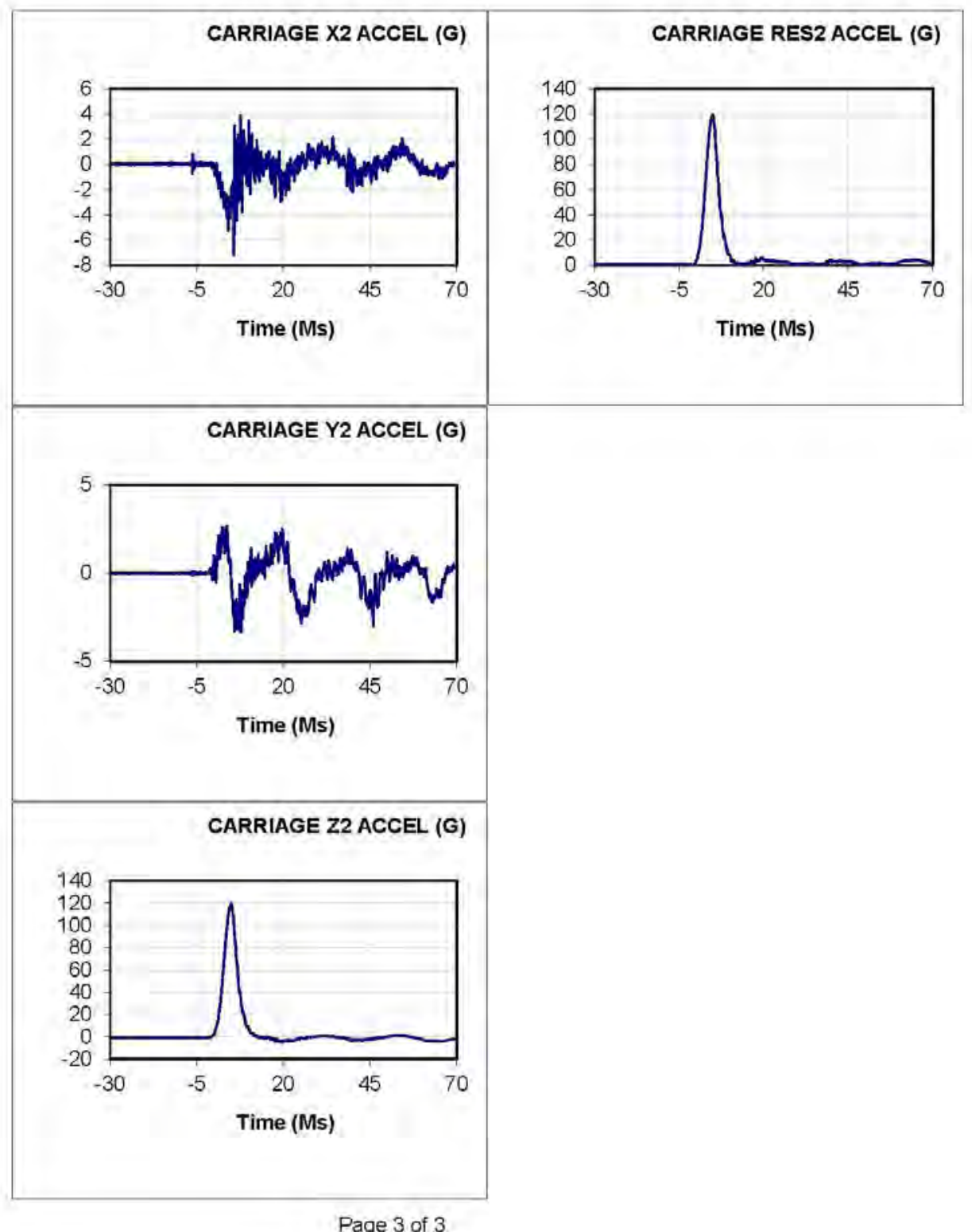

Page 3 of 3 